FABIANA HENRIQUES MACHADO DE MELO

\title{
Exploração funcional do processo de glicosilação aberrante em tumores: mecanismos envolvidos na atividade pró-migratória de galectina-3
}

Tese apresentada à Faculdade de Medicina da Universidade de São Paulo para obtenção do título de Doutor em Ciências

Área de concentração: Oncologia Orientador: Prof. Dr. Roger Chammas

São Paulo 


\section{DEDICATÓRIA}


A Deus,

pelo dom da vida

Aos meus pais, por acreditarem em mim 
AGRADECIMENTOS 


\section{AGRADECIMENTOS}

Aos meus pais, pois nada disso seria possível sem a ajuda deles:

A toda a minha família, que sempre me apoiou;

Ao meu orientador, Roger Chammas, por ter me dado a

opurtunidade de participar do Grupo de Adesão Celular:

A Dra. Maria Mitzi Brentani, pela opurtunidade de trabalhar no LIM 24;

A Prof. Marinilce por toda a ajuda na realização deste trabalho, pela amizade e pelas divertidas conversas no confocal;

A Dra. Ana Maria Moura, pela colaboração na realização deste trabalho;

Ao Diego, por sempre estar disposto a ajudar. Muito obrigada!!!

A Sueli Nonogaki, pela colaboração na realização deste trabalho;

Aos colegas do Grupo de Adesão Celular: Andréia, Luciana,

Mônica, Patrícia e Verônica;

A Mara por toda a ajuda, principalmente agora na fase final.

Muito obrigado!!! Descobri em você uma grande amiga!!!!

Ao Guilherme, por ter me feito companhia no lab por várias vezes; 
A Ana Paula e a Paty (farofa), pelas nossas risadas e discussões filosóficas! Sinto muitas saudades!!!

Aos colegas do LIM 24 que de uma forma ou de outra ajudaram na realização deste trabalho;

A Flávia, pela paciência em formatar essa tese!! Haja paciência!!! A Mari Jô, Ivanete, Jair e Willame pela constante disposição em ajudar!! Mari, vou sentir muito a sua falta!!!! Obrigada por tudo!!! A Cristina, pela contribuição artística dada a este trabalho: A FAPESP, pelo apoio financeiro. 
SUMÁRIO 


\section{SUMÁRIO}

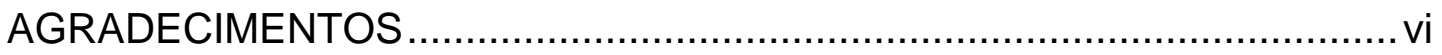

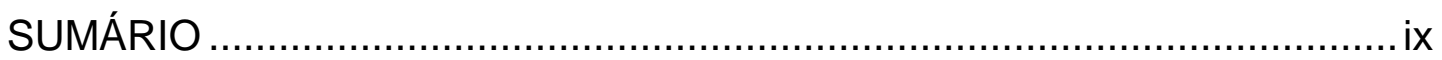



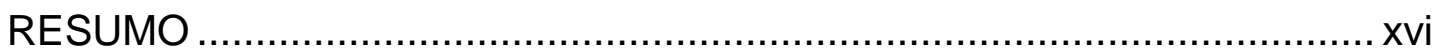

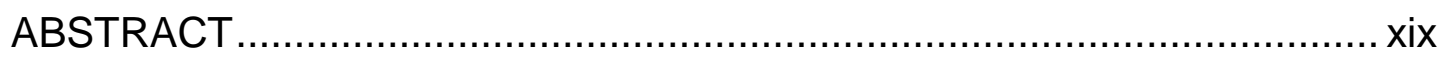

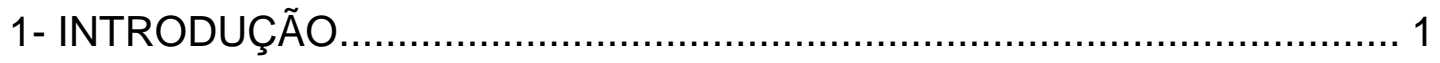

GLICOSILAÇÃO ABERRANTE DE TUMORES ............................................. 2

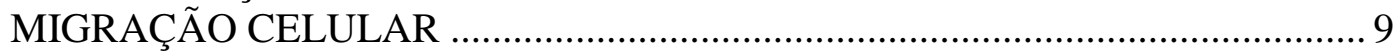

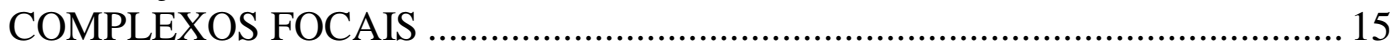

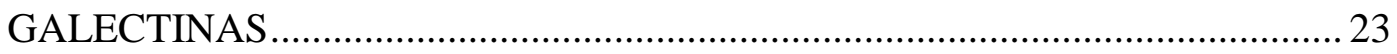



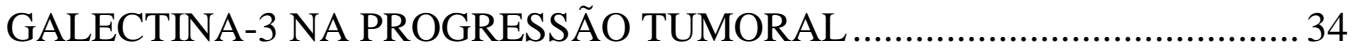

GALECTINA-3 COMO UMA MOLÉCULA DE DE-ADESÃO......................40



3 - DELINEAMENTO EXPERIMENTAL .......................................... 43

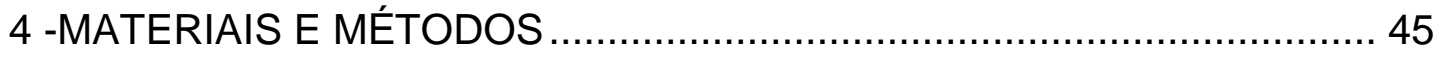

4.1 - GERAÇÃO DE GALECTINA-3 RECOMBINANTE .................................. 45

4.1.1 - EXPRESSÃO DA GALECTINA-3 RECOMBINANTE ...................... 45

4.1.2 - PURIFICAÇÃO DA rGAL-3 EM COLUNA DE AFINIDADE............ 46

4.1.3 - DIÁLISE DO MATERIAL PURIFICADO .............................................4 47

4.1.4- CONCENTRAÇÃO DA GALECTINA-3 RECOMBINANTE ................ 47

4.1.5 - DOSAGEM PROTÉICA …................................................................... 48

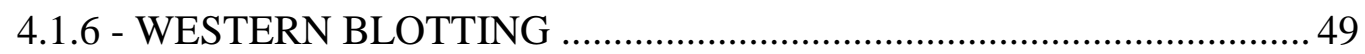

4.2- CONSTRUÇÃO E GERAÇÃO DA GALECTINA-3 CONJUGADA A



4.2.1- CONSTRUÇÃO DOS INICIADORES ................................................ 53

2.2- REAÇÃO DE POLIMERIZAÇÃO EM CADEIA (PCR) ........................... 53

4.2.2 - REAÇÃO DE POLIMERASE EM CADEIA (PCR) …..........................53

4.2.3 - DIGESTÃO COM ENZIMAS DE RESTRIÇÃO .................................. 55

4.2.4 - REAÇÃO DE LIGAÇÃO .................................................................... 56

4.2.5 - TRANSFORMAÇÃO DA BACTÉRIA .............................................. 56

4.2.6 - TRIAGEM DAS COLÔNIAS …......................................................... 57

4.2.7 - EXPRESSÃO DA PROTEÍNA HÍBRIDA: GAL-3 CONJUGADA A

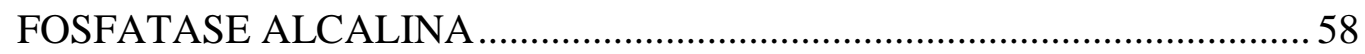

4.2.8 - SEQUENCIAMENTO DA GAL-3/FA .............................................. 59 
4.2.9 - WESTERN BLOTTING 60

4.3- ENSAIO DE ELISA (Enzyme Linked Immunosorbent Assay - ensaio de adsorção imunoenzimático) 61

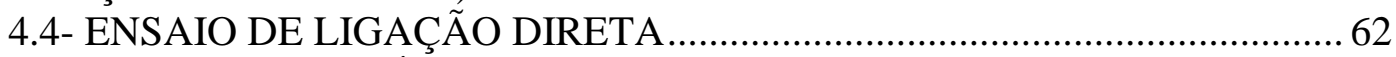

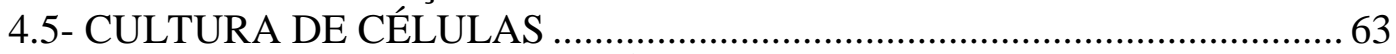

4.6- TRATAMENTO DAS CÉLULAS COM INIBIDORES DE $\mathrm{N}$ -

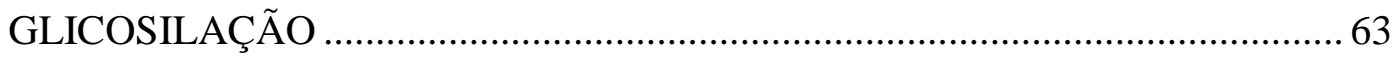

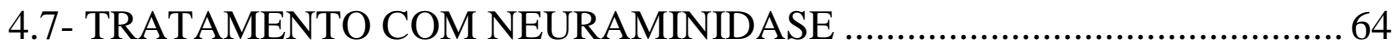

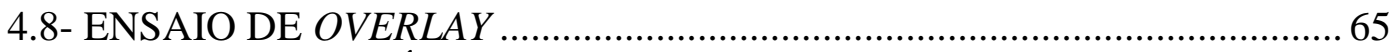

4.9- IMUNOISTOQUÍMICA: USO DA GALECTINA-3 CONJUGADA A

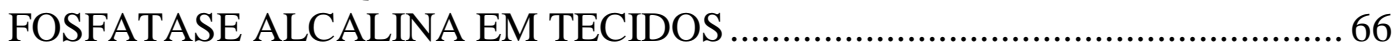

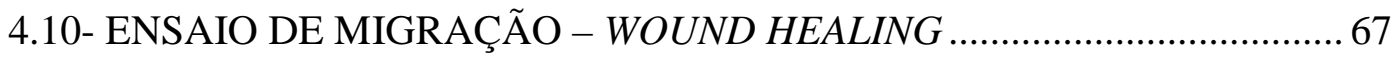

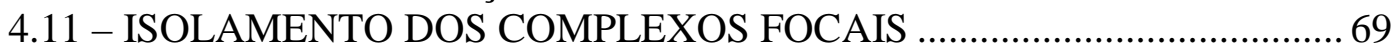

4.12- ANÁLISE DA ENDOCITOSE DE $\beta_{1}$ INTEGRINA POR CITOMETRIA



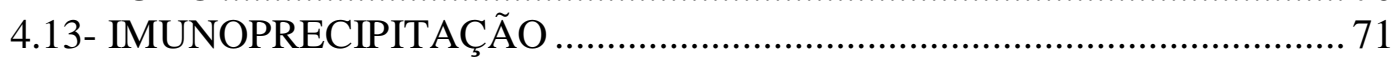



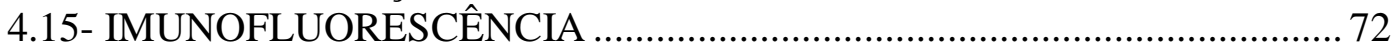

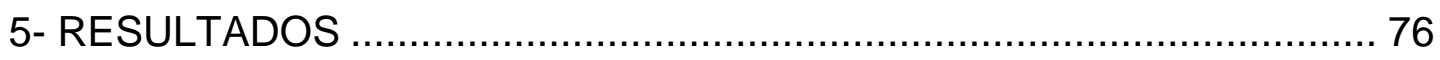

5.1 - EXPRESSÃO DA GALECTINA-3 HUMANA RECOMBINANTE ..... 76

5.2 - A LIGAÇÃO DA GALECTINA-3 HUMANA RECOMBINANTE À LAMININA-1 É INIBIDA NA PRESENÇA DE LACTOSE .............................. 78

5.3 - CONSTRUÇÃO E GERAÇÃO DA GALECTINA-3 CONJUGADA A

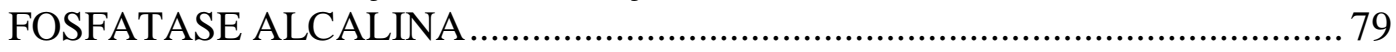

5.4 - SEQUENCIAMENTO DA GALECTINA-3 CONJUGADA A FOSFATASE

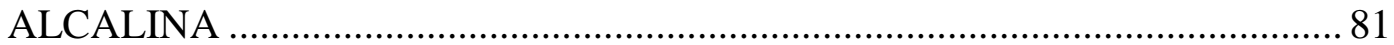

5.5 - EXPRESSÃO DA GALECTINA-3 CONJUGADA A FOSFATASE



5.6 - A LIGAÇÃO DA GAL-3/FA A LAMININA-1 É INIBIDA NA PRESENÇA

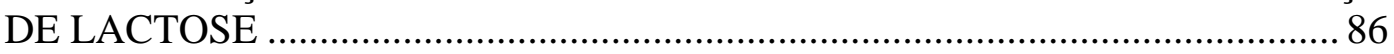

5.7 - GAL-3/FA POSSUI A MESMA ESPECIFICIDADE QUE GALECTINA-3

5.8 - A GAL-3/FA RECONHECE OLIGOSSACARÍDEOS $N$-LIGADOS DE


5.9 - O RECONHECIMENTO DOS LIGANTES DE GALECTINA-3 PELA GAL-3/FA NÃO É SENSÍVEL A DESIALILAÇÃO ......................................... 91

5.10 - REAÇÃO COM GAL-3/FA EM TISSUE-ARRAY .................................... 93

5.11 - EXPRESSÃO DOS LIGANTES DE GALECTINA-3 EM TUMORES



5.12 - ANÁLISE DA EXPRESSÃO E DA DISTRIBUIÇÃO DOS LIGANTES DE GALECTINA-3 EM TECIDOS DE CAMUNDONGO - LOCALIZAÇÃO NO TIMO E EM SARCOMAS EXPERIMENTAIS ......................................... 98 5.13 - A ADIÇÃO DE GALECTINA-3 EXÓGENA AUMENTA A MIGRAÇÃO DE CÉLULAS $\Sigma 12$ 101 5.14 - GALECTINA-3 É ENCONTRADA NOS COMPLEXOS FOCAIS......... 103 
5.15 - GALECTINA-3 SE LIGA NA SUPERFÍCIE DE CÉLULAS $\Sigma 12 \ldots \ldots \ldots . . . .104$ 5.16 - GALECTINA-3 INTERAGE DIRETAMENTE COM $\beta 1$-INTEGRINA 106 5.17 - A ADIÇÃO DE GALECTINA-3 EXÓGENA DIMINUIU A PRESENÇA DE FAK FOSFORILADO NOS COMPLEXOS FOCAIS 108 5.18 - A ADIÇÃO DE GALECTINA-3 ALTERA O PADRÃO DE FOSFORILAÇÃO DE PROTEÍNAS PRESENTES NOS COMPLEXOS FOCAIS 112

5.19 - ShP-2 É RECRUTADO PARA OS COMPLEXOS FOCAIS NA PRESENÇA DE GALECTINA-3 EXÓGENA 115

5.20 - CÉLULAS 112 EM MIGRAÇÃO INTERNALIZAM GALECTINA-3.. 118 5.21 - A ADIÇÃO DE GALECTINA-3 EXÓGENA EM CÉLULAS NÃO ADERENTES NÃO INDUZ A INTERNALIZAÇÃO DE $\beta 1$ INTEGRINA..... 120 5.22 - A ADIÇÃO DE GALECTINA-3 EXÓGENA NÃO ATIVA PAK ............ 122 5.23 - WORTMANINA, UM INIBIDOR DE PI3-KINASE, BLOQUEIA O AUMENTO DE MIGRAÇÃO DE FIBROBLASTOS CAUSADO PELA

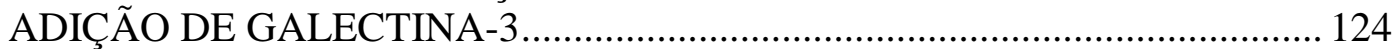





8 - REFERÊNCIAS BIBLIOGRÁFICAS ......................................... 149

ANEXO I

ANEXO II 


\section{LISTA DE ABREVIATURAS}




\section{LISTA DE ABREVIATURAS}

\begin{tabular}{|c|c|}
\hline APS & Persulfato de sódio \\
\hline ATP & Adenosina trifosfato \\
\hline BCIP & Bromo - cloro - indolilfosfato \\
\hline BSA & Albumina bovina sérica \\
\hline CRD & Domínio de reconhecimento de carboidratos \\
\hline DAB & 3,3-tetrahidrocloro diaminobenzidina \\
\hline DAPI & 4'6 - Diamidino - 2 fenilindol di-lactato \\
\hline DMEM & "Dulbecco's Modified Eagle Médium" \\
\hline DMN & Deoximanojirimicina \\
\hline DMSO & Dimetilsulfóxido \\
\hline DTT & Ditiotreitol \\
\hline EDTA & Ácido etilenodiaminotetraacético \\
\hline EGF & Fator de crescimento epidermal \\
\hline EGTA & $\begin{array}{l}\text { "Acetic acid, (ethylenebis (oxyethylenenitrilo)) tetra-, } \\
\text { ethylene glycol bis (2-aminoethyl ether)-N,N,N'N'- } \\
\text { tetraacetic acid" }\end{array}$ \\
\hline EHS & "Engelbreth - Holm - Swarm" \\
\hline ERK & "Extracellular signal regulated kinase" \\
\hline FAK & "Focal adhesion kinase" \\
\hline FITC & Isotiocianato de fluoresceína \\
\hline Gal & Galactose \\
\hline Gal3/Fa & Galectina-3 conjugada a fosfatase alcalina \\
\hline GICNAC & $N$-acetilglucosamina \\
\hline GNA & Galanthus nivalis agglutinin \\
\hline HRP & "Horseradish peroxidase" \\
\hline ILK & "Integrin-linked kinase" \\
\hline IPTG & Isopropil- $\beta$-D-tiogalactoperanosídeo \\
\hline Lac & Lactose \\
\hline LacNAC & $N$-acetilactosamina \\
\hline LB & Meio luria-bertani \\
\hline
\end{tabular}


LN

L-PHA

Mgat5

NBT

PAK

PBS

PCR

PDGF

PI3K

PIPES

PKC

PMSF

PNA

PVDF

PYK2

SDS

SDS/PAGE

Ser $^{6}$

SFB

SW

TBE

TBS

TEMED

VASP

VEGF

Wn
Laminina

Phaseolus vulgaris agglutinin

$N$-acetilgalactoaminiltransferase tipo 5

"Nitro blue tetrazole"

"p21 - activated protein kinase"

Tampão fosfato salino

Reação em cadeia da polimerase

Fator de crescimento derivado de plaqueta

Fosfoinositil 3-kinase

"Piperazine-1,4-bis (2-ethane-sulfonic acid)"

Proteína kinase C

Fenilmetilsulfonilfluoreto

Peanut agglutinin

"Hydrophobic polyvinylidene difluoride"

"Proline-rich tyrosine kinase 2"

Duodecil sulfato de sódio

Gel de poliacrilamida desnaturante (com SDS)

Serina 6

Soro fetal bovino

Swainsonina

Tris-ácido bórico - EDTA

Tampão tril-HCL salina

Tetrametiletinodiamina

"Vasodilator-stimulated phosphoprotein"

Fator de crescimento do endotélio vascular

Wortmanina 
RESUMO 


\section{RESUMO}

Melo, FHM. Exploração funcional do processo de glicosilação aberrante em tumores: mecanismos envolvidos na atividade pró-migratória de galectina-3. São Paulo [tese]. Faculdade de Medicina, Universidade de São Paulo; 2005. 169p.

Ao longo do processo de progressão tumoral, se observa alteração na expressão de glicoconjugados contendo oligossacarídeos $N$-ligados. Uma das formas mais comuns de glicosilação aberrante observada em células transformadas e em tumores humanos é representada por (poli)lactosaminas presentes em oligossacarídeos $N$-ligados. Estes glicanos são ligantes de galectina-3. Com o objetivo de identificar a expressão e distribuição dos ligantes de galectina-3 associados a processos fisiopatológicos, como a transformação maligna, desenvolvemos uma proteína quimérica, a galectina3 conjugada a fosfatase alcalina (Gal-3/FA). Observamos que a Gal-3/FA possui a mesma especificidade de galectina-3 e que pode ser usada como sonda em ensaios de overlay e ensaios de imunoistoquímica.

Entre os ligantes de galectina-3 identificamos a $\beta 1$ integrina, mediador de processos biológicos dependentes da interação célula-matriz como a migração celular. Linhagens de células de origem mesenquimal derivadas de tumores induzidos com metilcolantreno de animais selvagens (linhagens S11 e S12) e nulizigoto (linhagem $\Sigma 12$ ) para o gene da galectina3 foram estabelecidas. Avaliamos a capacidade migratória dessas células e os nossos resultados mostraram que células que expressam galectina-3 são mais migratórias em superfícies de laminina-1. Este dado sugere que a 
galectina-3 seja um modulador positivo do processo de migração celular em superfícies de laminina-1. No entanto, o mecanismo pelo qual a galectina-3 medeia esse processo não é conhecido. Células que possuem fenótipo mais migratório apresentam um estado intermediário de adesão. Nós observamos que a galectina-3 se encontra nos complexos focais. Na presença de galectina-3 observamos diminuição de FAK fosforilado e recrutamento da fosfatase SHP-2 para os complexos focais. A diminuição de FAK fosforilado no lamelipódio leva ao turnover dos complexos focais e ao aumento da migração celular. Analisamos também a via de sinalização e observamos que a galectina-3 não ativa PAK. Contudo, o inibidor de PI3quinase, wortmanina, inibiu o efeito pró-migratório de galectina-3. Esses dados reforçam a noção do papel de galectina-3 na modulação do processo de migração de fibroblastos transformados, funcionando como uma molécula de-adesiva.

Descritores: 1. Biotecnologia 2. Galectina-3 3. Movimento Celular 4. Sarcoma Experimental 5.Glicosilação 
ABSTRACT 


\section{ABSTRACT}

Melo, FHM. Exploiting the functional significance of aberrant glycosylation in tumors: mechanisms involved in the promigratory activity of galectin-3 [thesis]. São Paulo: "Faculdade de Medicina, Universidade de São Paulo"; 2005. 169p.

Altered expression of cell surface $N$-linked oligosaccharides are often associated with malignant transformation of cells. One of the most common forms of aberrant glycosylation in transformed cells and human tumors is the highly elevated $\beta 1,6$ branching of $N$-linked oligosaccharides caused by increased expression of $N$-acetylglucosaminytransferase $V$ (Mgat5). Galectin-3, a $\beta$-galactoside binding protein, binds preferentially to poly- $N$ acetyllactosamines, which are the products of Mgat5. In order to exploit this hallmark of cancer cells, we have developed a tool for in situ identification of these tumors associated glycoconjugates. Human galectin-3 was fused to bacterial alkaline phosphatase, generating a hybrid molecule displaying both the carbohydrate binding properties of galectin-3 and enzymatic activity of alkaline phosphatase (Gal-3/FA). Gal-3/FA has the same fine of galectin-3 which was confirmed in direct binding assays. The tool presented herein was therefore useful for several immunoenzymatic assays, and will allow to establish whether the expression pattern of galectin-3 ligands have any physiological or clinical significance.

We have identified $\beta 1$ integrin as a galectin- 3 ligand. $\beta 1$ integrins are the actual effector of cell adhesion and migration. We have established cell lines from methylcholantrene-induced sarcomas from both wild type and 
galectin-3 null mice. In this system, galectin-3 null cells were less migratory than control cells in laminin-1. When galectin-3 was transiently expressed in galectin-3 null sarcoma cells, it inhibited cell adhesion to laminin-1 and stimulate the migratory response to laminin-1. The addition of exogenous galectin-3 also enhanced the migratory capacity of $\Sigma 12$ cells in a carbohydrate dependent way. Galectin-3 was found in focal contacts of $\Sigma 12$ cells where it may interact with many glycoproteins containing polyllactosamines on the cell surface. Here we showed that $\beta 1$ integrins are among them. Exogenously added galectin-3 led to a decrease in phosphorylated-FAK in lamellipodia and increased the recruitment of Shp-2 phosphatase of migrating cells. The effect of galectin-3 in migration was not dependent on the activation of the p21-activated kinase (PAK). Wortmannin inhibited the increased migration elicited by galectin-3, suggesting the involvement of the PI3-kinase signaling in the galectin-3 pathway. We propose that extracellular galectin- 3 bound $\beta 1$ integrins and disrupted the focal adhesion plaque, thus favoring cell migration.

Descriptors: 1. Biotechnology 2. Galectin-3 3. Cell Movement 4. Experimental Sarcoma 5. Glycosylation 
INTRODUÇÃO 


\section{1- INTRODUÇÃO}

A tumorigênese é um processo constituído de três etapas: iniciação, promoção e progressão tumoral. É durante a iniciação e promoção, que ocorrem as primeiras alterações genéticas, que levam uma célula normal à transformação. Hanahan e Weinberg sugeriram que o câncer é resultado de 6 classes de alterações que interferem com a fisiologia normal de uma célula: (1) auto-suficiência de fatores de crescimento; (2) insensibilidade a fatores inibitórios de proliferação; (3) evasão da apoptose; (4) potencial replicativo infinito, (5) angiogênese sustentada e (6) invasão tecidual e metástase ${ }^{1}$. A fase de progressão tumoral corresponde à fase de aquisição de um comportamento invasivo, associado ou não a capacidade de formação de metástases à distância.

A disseminação de um tumor é um processo complexo que depende das interações entre as células tumorais e o seu microambiente tecidual. Para que ocorra a metástase, as células tumorais devem ser capazes de se soltar do tumor primário (perda da interação célula-célula) e escapar do tecido de origem, invadir a matriz extracelular até alcançar a corrente sanguínea ou linfática, atravessar a membrana basal e o endotélio dos vasos para cair na circulação, interagir com o endotélio vascular do órgão alvo, extravasar e proliferar nesse novo ambiente para formar o tumor secundário.

Ao longo do processo de progressão tumoral são encontradas alterações em várias moléculas que participam da interação célula-matriz, 
entre elas: integrinas, proteínas de matriz, caderinas, selectinas, componentes do citoesqueleto e componentes de vias de sinalização ${ }^{2,3}$.

Essas mudanças são resultado de alterações genéticas e/ou epigenéticas que levam a alterações na expressão, na conformação e/ou na atividade dessas proteínas. Além disso, essas proteínas podem sofrer mudanças no seu processo de modificação pós-traducional, entre elas a glicosilação, o que vem sendo chamado coletivamente de glicosilação aberrante de tumores ${ }^{4,5}$.

\section{GLICOSILAÇÃO ABERRANTE DE TUMORES}

Durante o processo de progressão tumoral, observamos alteração na glicosilação de vários glicoconjugados. Muitos glicanos, presentes tanto na superfície das células tumorais quanto na superfície das células do hospedeiro, têm sido identificados como elementos chaves em processos fisiopatológicos que ocorrem em várias etapas da progressão tumoral ${ }^{6}$. A glicosilação aberrante que ocorre em células tumorais está, dessa maneira, associada à transformação maligna, levando a alteração nas interações célula-célula e célula-matriz por afetar a função de moléculas de adesão como E-caderina, integrinas e selectinas ${ }^{7-9}$. Mudanças na glicosilação também afetam vias de sinalização que regulam a proliferação, diferenciação, migração e angiogênese, afetando, assim, não só as células tumorais propriamente ditas, mas também outras moléculas do microambiente tumoral ${ }^{10}$. 
A primeira evidência de que ocorriam alterações na glicosilação durante a progressão tumoral, veio da observação de que as células tumorais tinham maior habilidade de se ligar a lectinas vegetais do que a células normais ${ }^{11}$. Lectinas são proteínas que reconhecem carboidratos. Estas proteínas têm sido largamente utilizadas na detecção e isolamento de glicoproteínas e caracterização dos resíduos de carboidratos. Essa propriedade das lectinas é muito útil na identificação dos glicoconjugados presentes na superfície das células e em mudanças que ocorrem em processos como a transformação neoplásica ${ }^{12}$. Com o advento da tecnologia dos anticorpos monoclonais, foram identificados vários antígenos associados a tumor que são carboidratos-dependentes. Muitos desses anticorpos tumor-específicos reconheciam antígenos oncofetais presentes em glicoproteínas e glicoesfingolipídios tumorais ${ }^{13,14}$.

Existem várias famílias de glicoconjugados: (a) glicoproteínas contendo oligossacarídeos $\mathrm{N}$-ligados, onde uma $\mathrm{N}$-acetilglucosamina (GlcNAc) está ligada ao aminoácido asparagina presente na proteína; (b) glicoproteínas contendo oligossacarídeos O-ligados, os quais são encontrados predominantemente nas mucinas secretadas ou ligadas às membranas; (c) os glicoesfingolipídios, que consistem de oligossacarídeos ligados a ceramida; (d) as proteínas ligadas a âncoras de fosfatidilinositol, que são proteínas que contém uma cadeia de glicano ligado ao fosfatidilinositol; os glicosaminoglicanos que podem ser encontrados tanto como polissacarídeos livres como o ácido hialurônico (e) ou fazendo parte dos proteoglicanos (como o heparam-sulfato e condroitim-sulfato) (f); (g) 
além de várias proteínas citoplasmáticas e nucleares que contém o monossacarídeo $\mathrm{O}$-ligado $\mathrm{N}$-acetilglucosamina (O-GlcNAc) ligado a serina, freqüentemente em sítios que são normalmente fosforilados.

As alterações na glicosilação das células tumorais ocorrem de diferentes maneiras. Pode se encontrar aumento ou diminuição da expressão de determinadas estruturas, persistência de estruturas incompletas ou truncadas, acúmulo de precursores, e, mais raramente, o aparecimento de novas estruturas. A tabela abaixo ilustra alguns exemplos de como as alterações na glicosilação podem influenciar a progressão tumoral: 


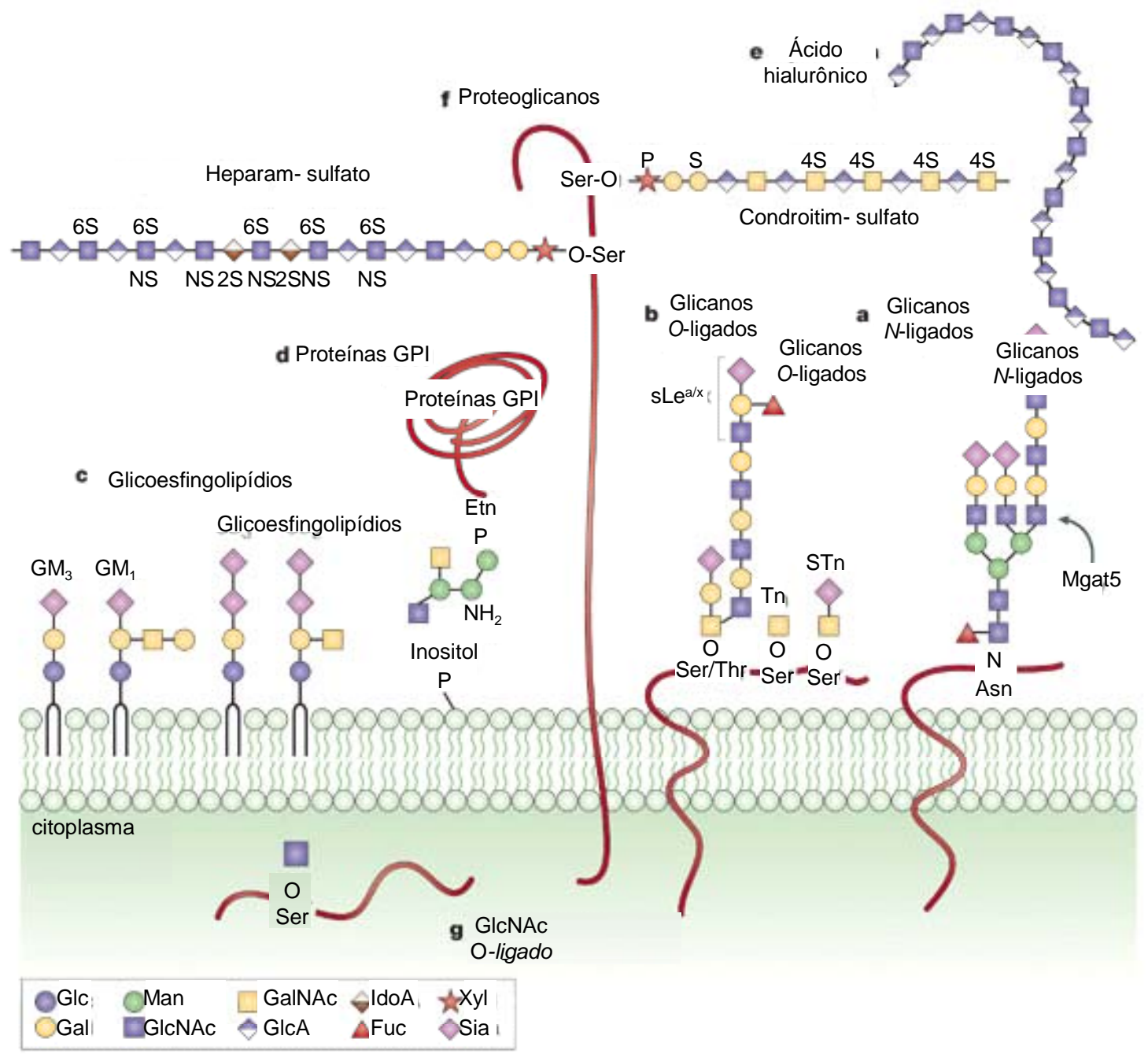

FIGURA 1. Glicanos envolvidos na progressão tumoral. a- $N$-glicanos presentes em glicoproteínas são covalentemente ligados aos resíduos de Asp. Ramificações típicas contém duas ou mais "antenas". A enzima Mgat5 é responsável pela adição das ramificações do tipo $\beta \quad 1 \rightarrow 6$. b- Glicanos $O$-ligados são covalentemente ligados aos resíduos de Ser ou Thr em glicoproteínas e mucinas. SLe ${ }^{x / a}$ são carboidratos determinantes compostos de 4 açúcares com ligações específicas e comumente tem sua expressão aumentada em mucinas de células tumorais. Tn e STn são antígenos tumorais compostos de cadeias de glicanos O-ligados truncados. c- Os glicoesfingolipídios são compostos de ceramidas ligadas a 1 ou mais açúcares. Os gangliosídios $\left(\mathrm{GM}_{1}, \mathrm{GM}_{3}\right)$ têm sido associados com o crescimento tumoral. d- Proteínas ligadas a GPI são ancoradas na parte externa da membrana plasmática por glicanos covalentemente ligados ao fosfatidilinositol. Glicosaminoglicanos podem ocorrer como cadeias livres (ácido hialurônico) (e) ou covalentemente ligados a proteínas formando proteoglicanos como heparam-sulfato e condrotim-sulfato (f). g- Várias proteínas citoplasmáticas e nucleares contém $N$-Acetilglucosaminas O-ligadas (O-GlcNAc). Os açúcares estão representados por símbolos geométricos coloridos.

Traduzido de Esko, D. e Furter, M. Nature Cancer Reviews. 5:526-542 (2005) 


\begin{tabular}{|c|c|c|c|}
\hline $\begin{array}{l}\text { GLICANOS } \\
\text { ENVOLVIDOS }\end{array}$ & FUNÇÕES & $\begin{array}{l}\text { POSSÍVEIS ALVOS } \\
\text { TERAPÊUTICOS }\end{array}$ & $\begin{array}{l}\text { EXEMPLOS DE } \\
\text { TUMORES }\end{array}$ \\
\hline \multicolumn{4}{|c|}{ Crescimento e proliferação } \\
\hline$N$-glicanos & $\begin{array}{l}\text { Sinalização de } \\
\text { fatores } \\
\text { decrescimento }\end{array}$ & $\begin{array}{c}\text { Inibidores alcalóides } \\
\text { do processamento de } \\
N \text {-glicosilação }\end{array}$ & $\begin{array}{l}\text { Mama, melanoma, } \\
\text { sarcoma de Ewing }\end{array}$ \\
\hline O-glicanos & $\begin{array}{l}\text { MUC-4 que medeia } \\
\text { a ativação do } \\
\text { receptor ERBB2 }\end{array}$ & $\begin{array}{l}\text { Imunoterapia tendo } \\
\text { como alvo MUC-4 }\end{array}$ & Mama \\
\hline Glicoesfingolipídios & $\begin{array}{c}\text { Controle de } \\
\text { sinalização através } \\
\text { das balsas lipídicas }\end{array}$ & $\begin{array}{l}\text { Inibidores da } \\
\text { glicosilação de } \\
\text { ceramidas }\end{array}$ & Mama \\
\hline O-glicanos & $\begin{array}{l}\text { Supressão da } \\
\text { apoptose (através da } \\
\text { ligação de galectina- } \\
\text { 3) }\end{array}$ & $\begin{array}{c}\text { Inibidores de galectina- } \\
3 \text { ( } \beta \text {-galactosídeos) }\end{array}$ & Cólon, pâncreas \\
\hline $\begin{array}{l}\text { Heparam-sulfato } \\
\text { proteoglicano }\end{array}$ & $\begin{array}{l}\text { Co-receptores de } \\
\text { fatores de } \\
\text { crescimento }\end{array}$ & $\begin{array}{c}\text { Inibição de } \\
\text { sulfotransferases; } \\
\text { miméticos de } \\
\text { heparam-sulfato }\end{array}$ & $\begin{array}{l}\text { Ovário, pâncreas, } \\
\text { hepático, renal }\end{array}$ \\
\hline \multicolumn{4}{|l|}{ Invasão } \\
\hline$N$-glicanos & $\begin{array}{c}\text { Alteração da } \\
\text { adesão tumoral } \\
\text { dependente de E- } \\
\text { caderina }\end{array}$ & $\begin{array}{c}\text { Inibidores alcalóides do } \\
\text { processamento de } N \text { - } \\
\text { glicosilação }\end{array}$ & Mama, cólon \\
\hline$N$-glicanos & $\begin{array}{c}\text { Diminuição da } \\
\text { interação entre as } \\
\text { células tumorais, } \\
\text { aumentado a } \\
\text { capacidade invasiva }\end{array}$ & $\begin{array}{c}\text { Inibidores de } \\
\text { sialiltransferases }\end{array}$ & Neuroblastoma \\
\hline $\begin{array}{l}\text { Heparam-sulfato } \\
\text { proteoglicano }\end{array}$ & $\begin{array}{l}\text { Estocagem de } \\
\text { fatores de } \\
\text { crescimento na } \\
\text { matriz }\end{array}$ & $\begin{array}{c}\text { Inibição de } \\
\text { sulfotransferases; } \\
\text { miméticos de } \\
\text { heparam-sulfato; } \\
\text { xilosidases, RNA anti- } \\
\text { senso para perlecam }\end{array}$ & $\begin{array}{l}\text { Mama, Cólon, } \\
\text { linfoma, } \\
\text { melanoma }\end{array}$ \\
\hline \multicolumn{4}{|l|}{ Metástases } \\
\hline O-glicanos & $\begin{array}{c}\text { Facilita a adesão das } \\
\text { células tumorais } \\
\left(\mathrm{Sle}^{\mathrm{x}}, \mathrm{Sle}^{\mathrm{a}}\right)\end{array}$ & $\begin{array}{c}\text { Anticorpos anti- } \\
\text { selectina; miméticos de } \\
\operatorname{Sle}^{\mathrm{x}}, \mathrm{Sle}^{\mathrm{a}}\end{array}$ & Cólon \\
\hline Glicanos $O$ - e $N$-ligados & $\begin{array}{c}\text { Promovem a } \\
\text { agregação das } \\
\text { células tumorais }\end{array}$ & $\begin{array}{c}\text { Inibidores da ligação } \\
\text { de galectina-3 ( } \beta \text { - } \\
\text { galactosídeos) }\end{array}$ & Melanoma \\
\hline \multicolumn{4}{|l|}{ Angiogênese } \\
\hline$N$-glicanos & $\begin{array}{c}\text { Promove a migração } \\
\text { de células } \\
\text { endoteliais }\end{array}$ & $\begin{array}{c}\text { Inibidores alcalóides } \\
\text { do processamento de } \\
\text { N-glicosilação }\end{array}$ & Próstata \\
\hline $\begin{array}{l}\text { Heparam-sulfato } \\
\text { proteoglicano }\end{array}$ & $\begin{array}{l}\text { Co-receptor para } \\
\text { fatores de } \\
\text { crescimento; } \\
\text { estocagem de } \\
\text { fatores de } \\
\text { crescimento na } \\
\text { matriz } \\
\end{array}$ & $\begin{array}{c}\text { Inibição de } \\
\text { sulfotransferases; } \\
\text { miméticos de } \\
\text { heparam-sulfato; } \\
\text { xilosidases, RNA anti- } \\
\text { senso para perlecam }\end{array}$ & $\begin{array}{l}\text { Cólon, mama, } \\
\text { melanoma }\end{array}$ \\
\hline
\end{tabular}

Tabela I. Exemplos de glicanos envolvidos na progressão tumoral. Traduzido de Esko, J. e Fuster, M. Nature Cancer Reviews. 5:526-542 (2005) ${ }^{10}$. 
Uma das formas mais comuns de $N$-glicosilação aberrante encontrada em modelos experimentais é o aumento dos níveis de glicanos $N$-ligados contendo ramificações do tipo $\beta 1 \rightarrow 6^{15,16}$.

O aumento da expressão de $\mathrm{N}$-glicanos tri e tetra antenares contendo a ramificação GIcNAc $\beta 1,6$ Man tem sido associada com o aumento do potencial metastático em modelos de tumores murinos e também tem sido considerado um marcador da progressão tumoral de tumores de mama e de cólon ${ }^{17,18}$. A estrutura GlcNAc $\beta 1,6$ Man é sintetizada pela enzima $\beta 1,6 \mathrm{~N}$-acetilglucosaminiltransferase $\mathrm{V}$ (Mgat5), localizada no Golgi medial. A atividade da enzima Mgat5 está aumentada em fibroblastos e células epiteliais transfectadas com os oncogenes $v$-src e T24-H-ras. Existem vários trabalhos mostrando a contribuição da enzima Mgat5 na transformação maligna. Animais nulizigotos para o gene da Mgat5 apresentaram diminuição do crescimento tumoral e do desenvolvimento de metástases ${ }^{19}$. Além disso, o aumento da expressão da enzima Mgat5 em células epiteliais resultou na perda da inibição por contato, no aumento da motilidade celular, na transformação morfológica em cultura, na formação de tumores em camundongos atímicos e no aumento da formação de metástases ${ }^{20,21}$. O aumento da expressão da enzima Mgat5 resultou no aumento de ramificações do tipo $\beta 1,6$ na subunidade $\beta 1$ das integrinas $\alpha 5 \beta 1$ de células tumorais, o que diminuiu a habilidade das integrinas de formar agregados na superfície das células. Como conseqüência as células tumorais se tornaram mais capazes de migrar através da matriz extracelular e de invadir as membranas basais ${ }^{22}$. 
Levando-se em consideração a importância da alteração da glicosilação durante a progressão tumoral, é natural se pensar no desenvolvimento de novas abordagens terapêuticas que tenham como alvo o bloqueio desse processo. Como mostrado na Tabela I, vários glicanos são possíveis alvos de abordagens terapêuticas. Alguns aspectos devem ser levados em consideração na escolha da abordagem. Primeiro, alguns glicanos podem agir em diferentes etapas da progressão tumoral, portanto, dependendo do glicano escolhido, este pode ter amplos efeitos. Segundo, dependendo da fase da progressão, uma determinada estratégia pode afetar várias interações dependentes deste glicano. Por exemplo, ao alterar a interação de selectinas, a adesão de plaquetas, linfócitos e células endoteliais seriam afetadas. Terceiro, algumas estratégias terapêuticas podem afetar mais de um tipo de interação carboidrato-proteína. Como exemplo, temos a heparina, que ao bloquear a interação selectina-Sle ${ }^{x}$, também bloqueia a invasão e angiogênese por inibir heparanases e a interação entre fatores de crescimento e seus receptores. Finalmente, devese levar em consideração os potenciais efeitos sinérgicos da inibição da glicosilação em combinação com as terapias convencionais de rádio- e quimioterapia ou terapias anti-angiogênicas ${ }^{10}$.

Várias abordagens terapêuticas estão em fase de teste clínico, entre elas, o uso da swainsonina, um inibidor competitivo do processo de $\mathrm{N}$ glicosilação que ocorre no complexo de Golgi e que bloqueia parcialmente a ação da enzima Mgat5 ${ }^{23,24}$. Porém, a desvantagem desse tipo de inibidor é 
que ele afeta toda a biossíntese de $N$-glicanos, levando a inúmeros efeitos colaterais.

Talvez, a escolha de qualquer terapia futura contra o câncer baseada no uso de glicanos, deveria ser guiada por testes sorológicos para glicanos considerados marcadores tumorais bem como por ensaios imunoistoquímicos.

A lectina vegetal L-PHA tem alta afinidade por estruturas com ramificações em configuração $\beta 1-6$ GlcNAc ${ }^{25}$. Existem alguns trabalhos mostrando evidências da correlação entre a expressão de moléculas L-PHA positivas e a aquisição de um fenótipo mais metastático ${ }^{18,26}$, no entanto, não existe consenso em relação ao significado clínico do L-PHA no diagnóstico e prognóstico de tumores.

\section{MIGRAÇÃO CELULAR}

A migração celular desempenha papel fundamental em vários processos biológicos, entre eles a embriogênese, inflamação e reparo, angiogênese e em processos fisiopatológicos como em infecções e na disseminação de tumores (metástases).

Para que as células tumorais consigam formar metástases, elas devem ter a capacidade de invadir e migrar pelos tecidos adjacentes. Por isso, o bloqueio da capacidade migratória e invasiva das células tumorais representaria uma interesante perspectiva terapêutica. Porém, o processo metastático é complexo, pois envolve várias vias de sinalização que permitem que as células tumorais proliferem, remodelem o microambiente, 
invadam e migrem pelos novos tecidos.

À medida que as células tumorais vão acumulando alterações genéticas e/ou epigenéticas e se tornam metastáticas, elas apresentam alteração na afinidade e avidez pela matriz extracelular. A alteração fenotípica é iniciada por mudanças na expressão das integrinas, secreção de proteases que remodelam a matriz extracelular e na deposição de novas moléculas de matriz. Conseqüentemente, tem-se a ativação de cascatas de sinalização que regulam a expressão gênica, a organização do citoesqueleto, a adesão e sobrevivência celular. Como resultado, as células tumorais se tornam mais invasivas, migratórias e capazes de sobreviver em microambientes diferentes.

A migração celular é um processo coordenado que envolve rápidas mudanças na dinâmica dos filamentos de actina juntamente com a formação e desmontagem de sítios de adesão celular ${ }^{27}$. Uma complexa relação entre o citoesqueleto de actina e os sítios de adesão celular leva a geração de protrusões na membrana e de forças de tração ${ }^{28}$.

Estímulos externos que controlam a migração celular são transduzidos em sinais bioquímicos intracelulares através da interação entre as integrinas e as proteínas da matriz extracelular; por fatores de crescimento (fatores motogênicos) que se ligam aos seus receptores cognatos presentes na superfície celular ou por estímulos mecânicos que promovem deformação do citoesqueleto de actina.

O processo de migração é acompanhado da polarização da célula migratória, que tem como conseqüência, a extensão da membrana, que 
forma estruturas chamadas lamelipódios e filopódios na frente de migração da célula. Nesse momento, pouca ou nenhuma adesão (interação célulamatriz) ou tração é necessária. Em seguida, as integrinas se ligam aos componentes da matriz formando clusters e se associam aos filamentos de actina do citoesqueleto. A reorganização dos filamentos de actina em fibras de estresse, por sua vez, estimula ainda mais a formação de clusters, aumentado, dessa maneira, a ligação das integrinas a matriz, num sistema de retroalimentação positiva. Como resultado, tem-se a formação dos complexos focais, que aplicam sobre a célula a força propulsiva para que ocorra a migração celular ${ }^{29}$.

A extensão do lamelipódio está associado à polimerização da actina, a qual pode se ligar a diferentes proteínas do citoesqueleto, podendo formar dessa maneira redes variadas de proteínas.

A motilidade celular requer ciclos de polimerização e despolimerização da actina. Evidências mostraram que a actina se movimenta continuamente em direção ao corpo celular numa velocidade de $1 \mu \mathrm{m} / \mathrm{min}$, sugerindo que ela é continuamente polimerizada na ponta do lamelipódio e despolimerizada perto da base da protrusão ${ }^{29,30}$.

Apesar do envolvimento dos complexos focais na ancoragem das células ao substrato ser bastante conhecido, pouco se sabe a respeito das forças contráteis que são transmitidas através dessas estruturas para direcionar o movimento. Resultados sugerem que complexos focais nascentes na frente de migração da célula exerçam forças transientes que são capazes de mover a célula para frente, enquanto placas de adesão 
maduras sirvam primariamente para ancorar as células ao substrato, transmitindo a tensão necessária para a movimentação celular ${ }^{31}$.

Para que as células migrem, também são necessários mecanismos que liberem os complexos focais do pólo posterior da célula, anteriormente formados na frente de migração e que reciclem os componentes dos complexos focais para o pólo anterior da célula. Um dos modelos propostos postula que o rompimento das interações entre o citoesqueleto e as integrinas em pontos específicos em resposta às forças contráteis, seria a causa do enfraquecimento e liberação dos complexos focais no pólo posterior da célula. Alterações de componentes do citoesqueleto como fosforilação e desfosforilação também influenciariam esse processo ${ }^{31,32}$.

À medida que as células se movimentam, os componentes do citoesqueleto que fazem parte dos complexos focais formados no pólo anterior vão se acumulando no pólo posterior da célula. Resultados mostraram que no caso dos fibroblastos, as integrinas liberadas dispersam na superfície celular ${ }^{33}$. Uma outra possibilidade é que as integrinas sejam rapidamente internalizadas a partir da superfície celular. Dessa maneira, tem sido proposto que as integrinas e talvez outros componentes dos complexos focais sejam endocitados no pólo posterior da célula e reciclados para frente de migração. Este seria um mecanismo para que essas proteínas pudessem ser recrutadas para a formação de novos complexos focais. Suportando este modelo, foi mostrado que as integrinas de neutrófilos em migração estão colocalizadas com um marcador do compartimento de reciclagem endocítico 34. 
A dinâmica das proteínas do citoesqueleto em fibroblastos é regulada pelas proteínas Rho da família Ras. A atividade das proteínas Rho é regulada pelas integrinas, fatores de crescimento e citocinas. A ativação de RhoA, Rac1 e Cdc42 leva à formação das fibras de estresse, das ondulações de membrana/lamelipódios (ruffles) e dos filopódios, respectivamente. Além disso, a ativação dessas proteínas também promove a formação dos complexos focais. Uma vez ativado, Rac ativa a fosfolípidequinase, que converte o fosfotidilinositol-4-fosfato (PIP) em fosfotidilinositol4,5-bifosfato (PIP2). PIP2, então, induz a desproteção dos filamentos de actina, levando ao aumento da polimerização da actina e conseqüentemente da migração celular ${ }^{35,36,37}$. 
FIGURA MIGRAÇÃO CELULAR (FIGURA 2) 
FIGURA 2. Modelo de migração celular em 3D. Passo 1: protusão do lamelipódio. Os filamentos de actina em elongação se ligam a proteínas adaptadoras como o complexo ARP2/3 e WASP, responsáveis pela nucleação da actina, e iniciam a formação do lamelipódio. PI3K e PI45K geram os fosfoinositóis de membrana (PIPs) que regulam a atividade das GTPases Rac, Cdc 42 e Rho, que por sua vez regulam a formação do lamelipódio, filopódio e fibras de estresse, respectivamente. Passo 2: Interação célula-matriz e formação dos complexos focais. As integrinas se ligam a proteínas da matriz, formam clusters e recrutam proteínas adaptadoras e de sinalização, como $F A K$, talina, paxilina e $\alpha$-actinina, induzindo a fosforilação e desfosforilação desses componentes (sinalização outside-in). A formação dos complexos focais é induzida direta e indiretamente por várias vias de sinalização como PI3K, PKC e Rho GTPases (sinalização inside-out). Passo 3: Recrutamento de proteases e proteólise focalizada. Próximo a superfície celular, proteases clivam componentes da matriz, como colágenos, fibronectina e laminina, bem como, pró-MMPs que se tornam ativas. Passo 4: Contração celular pela actomiosina. A ativação da miosina II é regulada pelo balanço entre a fosforilação da MLC pela MLCk e sua desfosforilação pela MLCPase. A miosina II ativada se liga aos filamentos de actina (então chamados actomiosina) e gera a contração da actomiosina. Passo 5: Desadesão da parte posterior da célula. Os complexos focais se desmontam por vários mecanismos: quebra dos filamentos de actina, promovendo o seu turnover; clivagem de componentes dos complexos como talina e as porções citoplasmáticas das integrinas pela protease citoplasmática calpaína e clivagem proteolítica dos receptores de adesão. Em seguida, as integrinas se soltam da matriz e podem ser internalizadas pela via endocítica para reciclagem ou depositadas na matriz.

\section{COMPLEXOS FOCAIS}

Adesões com a matriz extracelular são formadas por todos os tipos de células aderentes, o que difere é a sua morfologia, o seu tamanho e a sua distribuição subcelular. Muitas dessas adesões tem 2 características comuns: elas são mediadas por integrinas e interagem com o citoesqueleto de actina. Os ligantes extracelulares que ancoram essas adesões incluem fibronectina, laminina, vitronectina e vários tipos de colágeno.

Já foram identificadas mais de 50 proteínas localizadas nas adesões celulares ${ }^{38}$. As adesões fibrilares são estruturas centrais que contém $\alpha 5 \beta 1$ integrina, tensina e acotpaxina ${ }^{36}$. Os complexos focais são adesões pequenas $(1 \mu \mathrm{m})$ induzidas pela ativação de Rac na periferia celular ${ }^{39}$. São as estruturas localizadas no lamelipódio, não detectável em alguns tipos celulares, que estão associadas com a migração celular ${ }^{40,41}$. Sob tensão, os 
organizadas, como as placas de adesão focal ${ }^{42-44}$. As placas de adesão focal são estruturas relativamente estáveis que tendem a inibir a migração celular. A formação das placas de adesão é estimulada por Rho e parece estar envolvida na geração da força contrátil que está associada a processos não relacionados com a migração, como a formação e remodelamento das matrizes extracelulares.

Em células estacionárias, os complexos focais se movem em relação ao substrato e a borda da célula, mantendo constante a sua área e forma. Já nas células migratórias, os complexos focais apresentam pouco ou nenhum movimento. Durante a migração dos fibroblastos, os complexos focais são formados no pólo anterior da célula, permanecem fixos ao substrato enquanto as células migram sobre eles e finalmente são liberados na parte posterior da célula ${ }^{36}$. Como os complexos focais provêm sítios de adesão para as células migrarem, o movimento dos complexos focais nas células estacionárias pode prevenir a geração da tração necessária para o processo de migração.

As proteínas presentes nos complexos focais podem ser divididas de acordo com as suas funções: proteínas do citoesqueleto, como tensina, vinculina, paxilina, $\alpha$-actinina e talina; tirosino-quinases, como Src, FAK (focal adhesion kinase), PYK2; serino/treonino -quinases, como PKC, ILK e PAK; tirosino-fosfatases, como SHP-2 e LAR PTP e outras enzimas como PI 3-quinase e calpaína II. Algumas dessas proteínas podem diretamente se ligar aos filamentos de actina, como vinculina, tensina, $\alpha$-actinina e VASP e 
outras à cauda citoplasmática das integrinas, como tensina, talina, ILK e $\alpha$ $\operatorname{actinina}^{42}$.



FIGURA 3. Arquitetura molecular dos complexos focais. As integrinas se conectam ao citoesqueleto da célula em sítios de adesão chamados complexos focais. Os complexos focais são estruturas dinâmicas compostos de proteínas estruturais e regulatórias que transduzem sinais externos para a célula (sinalização outside-in) e também podem regular a afinidade e avidez das integrinas (sinalização inside-out). As proteínas paxilina e talina recrutam FAK e vinculina para os complexos focais. Em seguida, $\alpha$-actinina é fosforilada por FAK, se liga a vinculina, organizando os feixes de actomiosina.

Traduzido de Schlaepfer, D. et al. Nature Cancer Reviews. 6:56-68 (2005)

A interação entre as integrinas e a matriz extracelular, a ligação de fatores de crescimento aos seus receptores e a estimulação com neuropeptídios como bombesina ou vasopressina e o componente do soro, o 
ácido lisofosfatídico (LPA), podem iniciar o recrutamento das proteínas do citoesqueleto e a montagem dos complexos focais. O mecanismo exato pelo qual a interação receptor-ligante induz o recrutamento e organização dessas proteínas não é totalmente conhecido.

Evidências experimentais mostram que na formação dos complexos focais tem-se o recrutamento individual ou de classe de componentes de adesão ao redor de um centro de nucleação ao invés do recrutamento de complexos já formados e estabilizados. Beads de poliestireno recobertos com ligantes de integrinas ou anticorpos ativados têm sido usados para mostrar que a agregação das integrinas em clusters induz o recrutamento de FAK e de tensina ${ }^{45}$. A ativação de FAK é dependente da adesão celular mediada pelas integrinas. Apesar de FAK e das integrinas estarem colocalizadas nos complexos focais, existem evidências de que FAK não se ligue diretamente à porção citoplasmática das integrinas. A interação seria de maneira indireta através da associação de FAK com proteínas associadas a integrina, como paxilina e talina ${ }^{46,47}$. A ativação de FAK se inicia com a autofosforilação do resíduo de tirosina 397, o que promove a ligação da proteína Src e sua ativação conformacional, o que resulta na ativação do complexo FAK-Src ${ }^{46,48}$. Além de promover a máxima ativação de FAK, o recrutamento de Src para o complexo de sinalização FAK-Src facilita a fosforilação de várias proteínas associadas a FAK, como paxilina e p130Cas ${ }^{49,50}$. A sinalização downstream a p130Cas resulta no aumento da atividade de Rac e na formação dos ruffles de membrana e do lamelipódio, o que promove o aumento da motilidade celular ${ }^{51,52}$. Paxilina e p130Cas 
podem recrutar outras moléculas para os complexos focais e regular a organização do citoesqueleto de actina. Fibroblastos nulizigotos para o gene da paxilina e de p130Cas apresentam defeitos na formação do citoesqueleto cortical, espraimento e migração celular ${ }^{53,54}$. Quando os complexos começam a se estabilizar, a $\alpha$-actinina é recrutada e começa a se colocalizar com a paxilina em pequenos pontos do lamelipódio recém-formado. Estes pequenos pontos contendo $\alpha$-actinina se expandem e formam extensões parecidas com fibras de estresse que se estendem pelo corpo da célula. A presença da $\alpha$-actinina serve para estabilizar a paxilina, uma vez que esta não recicla mais para a base do lamelipódio e coincide com o movimento centrípeto dos complexos focais ${ }^{55}$.

Como dito anteriormente, os complexos focais são formados nos lamelipódios e a dinâmica de recrutamento das proteínas para a sua montagem é responsável pela geração e manutenção das forças de propulsão e tração necessárias para o processo migratório. Complexos focais recém-formados exercem sobre as células intensa força propulsiva e são responsáveis pela migração celular. À medida que mais proteínas são recrutadas para a formação dessas placas de adesão e estas amadurecem, a tração necessária para a migração vai diminuindo. Dessa maneira, os complexos focais passam a ancorar as células à matriz extracelular e estas se tornam menos migratórias ${ }^{31}$. Por isso, a migração depende de um processo de liberação das células de sua matriz que é promovido pela desmontagem dos complexos focais. 
O processo de desmontagem dos complexos focais é observado tanto no pólo posterior da célula, onde promove a retração e conseqüente translocação do corpo celular, quanto na frente de migração, onde é acompanhado da formação de novas adesões. A diminuição da interação entre as integrinas e a matriz extracelular é pelo menos em parte estimulado por forças contráteis ${ }^{40}$. Sob essas condições, as integrinas se mantêm associadas ao substrato, enquanto os componentes do citoesqueleto, que estão sob tensão, deslizam pelo corpo celular e eventualmente se dispersam.

$\mathrm{Na}$ frente de migração ocorre o turnover dos complexos focais, ou seja, ciclos de formação e desmontagem desses complexos. Existem evidências mostrando que a composição molecular dos complexos focais determina, pelo menos em parte, se estes vão ser reciclados ou vão amadurecer. Complexos localizados no lamelipódio contendo paxilina se desmontam e formam novos complexos focais na frente de migração. Porém, se houver $\alpha$-actinina nessas adesões, elas não se desmontam, mas sim se estabilizam e amadurecem ${ }^{55}$.

A família Rho de GTPases é uma reguladora chave da dinâmica de montagem e desmontagem dos complexos focais. Em células migratórias, Rac é necessário para a formação de novas adesões no lamelipódio, enquanto Rho é responsável pelo amadurecimento de complexos já existentes ${ }^{56}$. Rac pode regular o turnover dos complexos focais diretamente através da ativação de seus efetores, ou indiretamente por antagonizar Rho. Existem evidências do envolvimento de PAK (p21 activated kinase), efetor 
de Rac, na dinâmica de desmontagem dos complexos focais. PAK é recrutado para os complexos focais por Rac e Cdc 42 ativados o que sugere a sua participação no turnover dessas estruturas. O aumento da expressão de PAK induz alterações na organização do citoesqueleto, diminuindo a formação das fibras de estresse e do lamelipódio. Além disso, PAK aumenta a formação de novas adesões na frente de migração ${ }^{57-60}$.

Estudos com animais nulizigotos mostraram o envolvimento de várias proteínas na dinâmica de formação e desmontagem dos complexos focais. Apesar do recrutamento de FAK para os complexos focais estar associada ao aumento da sua fosforilação, a formação dos complexos focais em fibroblastos FAK -/- é normal ${ }^{61}$, indicando que FAK não é essencial para a formação desses complexos. No entanto, essas células apresentam redução do espraiamento, da capacidade migratória e aumento no número e tamanho das adesões localizadas na periferia. A expressão de FAK normal ou de formas mutantes de FAK em células FAK -/- mostrou que a autofosforilação de FAK no resíduo de tirosina 397, a sua atividade de quinase e a primeira região que se liga a proteínas contendo domínios SH3 são importantes para a migração dessas células ${ }^{62,63}$. Esses resultados sugerem o envolvimento de FAK no turnover dos complexos focais.

Existem outros trabalhos mostrando que as alterações nos complexos focais e nos filamentos de actina podem envolver a regulação da atividade da $\alpha$-actinina, uma proteína que promove a ligação cruzada dos filamentos de actina e tem papel importante na manutenção da ligação entre os complexos focais e as fibras de estresse ${ }^{27}$. FAK fosforila o resíduo de 
tirosina 12 da $\alpha$-actinina, o que causa a redução da ligação desta aos filamentos de actina ${ }^{64}$. A $\alpha$-actinina não é fosforilada em células FAK-/-, consequentemente não ocorre a diminuição da interação entre os filamentos de actina e a desmontagem dos complexos focais.

Para que ocorra o turnover dos complexos focais e, dessa maneira, se formem novos complexos e se iniciem subseqüentes rodadas de fosforilação em novas adesões, FAK deve ser desfosforilado. Existem evidências mostrando o envolvimento da tirosino-fosfatase SHP-2 na regulação da fosforilação de FAK e na migração de fibroblastos. Células SHP-2 -I- apresentam diminuição do espraimento e da migração celular em fibronectina e maior número de adesões focais ${ }^{65,66}$. O nível de fosforilação de FAK nessas células está aumentado, resultando na constante interação entre o domínio SH2 de Src e FAK, o que não ocorre em células normais após a desadesão. Esta interrupção na regulação da fosforilação de FAK e na sua interação com Src poderia ser a causa dos defeitos de migração observados nas células SHP-2 -I-, conferindo a SHP-2 papel no turnover dos complexos focais.

Mais recentemente foi mostrado que os defeitos de migração observados nas células SHP-2 -I- são devido ao aumento da fosforilação da tirosina 12 da $\alpha$-actinina, o que reduz a ligação cruzada entre as fibras de estresse e previne a maturação dos complexos focais ${ }^{67}$. Conseqüentemente, células SHP-2 -I- apresentam elevados níveis de turnover dos complexos focais, enquanto células FAK -I- apresentam redução do turnover $\{1515\}$. 
Análises da freqüência de formação e desmontagem dos complexos focais na protrusão de células em migração confirmaram o envolvimento de FAK e Src e mostraram a importância de outras proteínas como p130CAS, paxilina, ERK e MLCK na desmontagem dos complexos focais ${ }^{68}$.

\section{GALECTINAS}

As galectinas, inicialmente denominadas lectinas do tipo-S, representam um grupo de proteínas da família das lectinas definidas por duas propriedades: afinidade por $\beta$-galactosídeos e homologia primária no seu domínio de reconhecimento de carboidratos (CRD) ${ }^{69}$. Elas estão amplamente distribuídas pelo reino animal, sendo encontrada desde poríferos até vertebrados. A maior parte das galectinas é solúvel e requer condições redutoras para manter sua atividade na ausência de ligantes. Atualmente pelo menos quinze galectinas já foram identificadas numa variedade de tecidos de mamíferos ${ }^{70-74}$ (Tabela II).

A primeira lectina do tipo-S foi descrita em 1975 no órgão elétrico da enguia elétrica. Esta foi nomeada eletrolectina e possuía atividade de hemaglutinação inibível por $\beta$-galactosídeos. Em 1976 foi encontrada nos extratos de coração e pulmão de bezerro, a primeira galectina de mamíferos, hoje denominada galectina-1. Esta foi isolada por cromatografia de afinidade em assialofetuína-Sepharose ${ }^{\circledR}$ e sua massa molecular aparente era de aproximadamente $15 \mathrm{KDa}$. Baseada na sua natureza solúvel, homologia na estrutura primária do CRD e necessidade de condições redutoras para manter sua atividade, em 1988 essas proteínas foram nomeadas de lectinas 
do tipo-S, alusão à necessidade da presença de sulfidrilas reduzidas (-SH) para sua função. Porém, com estudos de mutagênese direta, verificou-se que a presença de grupos sulfidrila livres não era essencial para a interação com os $\beta$-galactosídeos. Dessa maneira, as lectinas do tipo-S passaram a ser denominadas galectinas ${ }^{75}$.

De acordo com a sua arquitetura, as galectinas foram classificadas em 3 tipos: proto, quimera e tandem. As galectinas do tipo proto incluem as galectinas 1, 2, 5, 7, 10, 11, 13, 14 e 15. Estas apresentam 1 CRD em sua estrutura terciária. Alguns membros desta subfamília podem formar homodímeros. Nas galectinas do tipo quimera o domínio CRD está ligado ao domínio N-terminal que possui seqüências de tirosina, prolina e glicina que se repetem de 8 a 12 vezes com comprimento de nove resíduos de aminoácidos. O único membro dessa família é a galectina-3, que ao contrário da galectina-1, não necessita de condições redutoras para manter a sua atividade. O terceiro grupo é composto pelas galectinas 4, 6, 8, 9 e 12 constituídas por 2 CRDs diferentes localizados em sua estrutura terciária ${ }^{76}$. 
a

\begin{tabular}{|c|c|c|}
\hline Tipo & Estrutura & Galectina \\
\hline \multirow[t]{2}{*}{$1 \mathrm{CRD}$} & 8 & $1,2,6,7,10,11,13,14,15$ \\
\hline & MC & 3 \\
\hline $2 \mathrm{CRD}$ & $2 \times 6$ & $4,6,8,9,12$ \\
\hline
\end{tabular}

b

Interações célula-
célula e célulamatriz

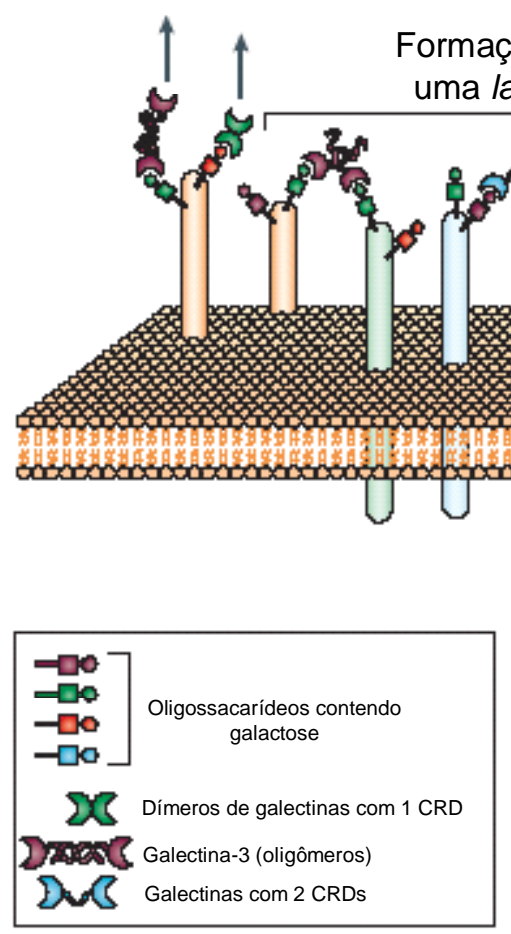

Transdução de sinal

FIGURA 4. A família das galectinas. a. As galectinas são proteínas da família das lectinas caracterizadas por conter um domínio de reconhecimento de carboidratos (CRD) conservado e ter afinidade por $\beta$-galactosídeos. 15 galectinas já foram identificadas, as quais podem ser subdivididas em 3 grupos: aquelas que contém 1 CRD (galectinas 1, 2, 5, 7, 10, 11, 13, 14 e 15); aquelas que contém dois CRDs distintos em tandem (galectinas 4, 6, 8, 9 e 12) e a galectina-3 que é o único representante do tipo quimera e pode formar oligômeros. b. A galectina-3 forma oligômeros quando interage com os seus ligantes podendo ativar vias de sinalização. As galectinas podem causar a agregação de glicoconjugados multivalentes na superfície celular, levando a formação de redes. Elas podem também fazer uma ponte entre as células ou entre as células e a matriz extracelular (ECM).

Traduzido de Rabinovich G. e Liu, F-T. Nature Cancer Reviews. 5:29-41 (2005) 
Tabela II. Distribuição tecidual e algumas características estruturais das galectinas de mamíferos. Adaptado de GABIUS, H. Eur. J. Biochem. 243:543-576 (1997) ${ }^{12}$.

\begin{tabular}{|c|c|c|}
\hline NOME & DISTRIBUIÇÃO & CARACTERÍSTICAS ESTRUTURAIS \\
\hline $\begin{array}{c}\text { Galectina-1 } \\
\text { (galaptina, L-14) }\end{array}$ & Muitos tipos celulares & $\begin{array}{l}\text { Homodímero, } 1 \text { CRD/subunidade (12-16 } \\
\text { KDa), protótipo }\end{array}$ \\
\hline Galectina-2 & $\begin{array}{l}\text { Intestino delgado, clone de } \\
\text { hepatoma humano }\end{array}$ & $\begin{array}{l}\text { Homodímero, } 1 \text { CRD/subunidade (43\% de } \\
\text { identidade com a galectina-1, } 14 \mathrm{KDa}) \text {, } \\
\text { protótipo }\end{array}$ \\
\hline $\begin{array}{c}\text { Galectina-3 (cBP, } \\
\text { CBP-35, Mac-2, L- } \\
\text { 29, L-34) }\end{array}$ & Muitos tipos celulares & $\begin{array}{l}\text { Monômero com } 1 \text { CRD, repetições ricas } \\
\text { em prolina, tirosina e glicina na porção N- } \\
\text { terminal (29-37 KDa), tipo quimérico }\end{array}$ \\
\hline Galectina-4 & $\begin{array}{c}\text { Cólon, intestino delgado, } \\
\text { estômago, epitélio oral, esôfago }\end{array}$ & $\begin{array}{l}\text { Monômero com } 2 \text { CRDs parcialmente } \\
\text { homólogos, mas distintos, unidos por uma } \\
\text { região linker (36 KDa), tipo tandem }\end{array}$ \\
\hline Galectina-5 & Eritrócitos & $\begin{array}{l}\text { Monômero com } 1 \text { CRD, (17 KDa), } \\
\text { protótipo, 85\% de identidade com o } \\
\text { domínio C-terminal da galectina-9 }\end{array}$ \\
\hline Galectina-6 & Intestino delgado, cólon & $\begin{array}{l}2 \text { CRDs (33 KDa), tipo tandem, } 85 \% \text { de } \\
\text { identidade com a galectina-4 }\end{array}$ \\
\hline Galectina-7 & Queratinócitos & $\begin{array}{c}1 \text { CRD (12,7 KDa), protótipo, marcador de } \\
\text { estratificação do epitélio }\end{array}$ \\
\hline Galectina-8 & $\begin{array}{l}\text { Vários tecidos (rim, timo, } \\
\text { pulmão, fígado) }\end{array}$ & $\begin{array}{l}\text { Homólogo as galectinas } 4 \text { e } 6 \text {, possui } 2 \\
\text { CRDs unidos com um peptídio linker (34 } \\
\text { KDa), tipo tandem }\end{array}$ \\
\hline Galectina-9 & Timo, rim, linfoma de Hodgkin & $\begin{array}{l}\text { Possui 85\% de identidade com o domínio } \\
\text { C-terminal da galectina-5 (35 KDa) }\end{array}$ \\
\hline $\begin{array}{c}\text { Galectina-10 } \\
\text { (Proteína cristal de } \\
\text { Charcot-Leyden) }\end{array}$ & $\begin{array}{l}\text { Principal constituinte auto- } \\
\text { cristalizável de eosinófilos e } \\
\text { basófilos }\end{array}$ & $\begin{array}{l}\text { dímero e atividade lisofosfolipase (17 } \\
\text { KDa) }\end{array}$ \\
\hline GRIFIN & Cristalino (murino) & $\begin{array}{c}1 \text { CRD, dímero (ainda não foi identificada } \\
\text { atividade de lectina) }\end{array}$ \\
\hline Galectina-12 & Vários tecidos & 2 Domínios homólogos ao CRD \\
\hline Galectina-13 & Placenta e tecidos fetais & Homodímero \\
\hline Galectina-14 & Eosinófilos & $\begin{array}{l}\text { Homólogo a galectina-9; galectina do tipo } \\
\text { protótipo }\end{array}$ \\
\hline Galectina-15 & Células epiteliais do endométrio & 1 CRD (14 kDa); protótipo \\
\hline
\end{tabular}




\section{GALECTINA-3}

A galectina-3 é uma proteína com cerca de 30 KDa e é composta por três domínios estruturais distintos: o domínio amino terminal composto de 12 aminoácidos, uma seqüência colágeno-símile rica em glicina, tirosina e prolina, a qual serve como substrato para metaloproteinases e o domínio carboxi-terminal, estrutura globular onde está localizado o CRD ${ }^{71}$.

A galectina-3 foi primeiramente descrita em 1982 como um componente da superfície de macrófagos murinos (Mac-2), reconhecida por um anticorpo monoclonal, em células estimuladas com tioglicolato. Estudos de clonagem e sequenciamento subseqüentes mostraram a presença de homólogos de Mac-2 em outras células inflamatórias de roedores e humanas. Além disso, esta molécula era idêntica ou similar as proteínas que se ligam a $\beta$-galactosídeos com massa molecular de 30-35 KDa, entre elas a proteína ligadora de IgE em basófilos, a proteína CBP 35 de fibroblastos 3T3 murinos, a proteína CBP 30 encontrada nas células BHK ${ }^{77-79}$.

A galectina-3 é codificada por um gene de cópia única no genoma humano (designado LGALS3) composto por seis exons e cinco introns e tem aproximadamente $17 \mathrm{~Kb}$. O promotor do gene da galectina-3, não contém TATAbox, assim como o promotor do gene murino. No entanto, existem múltiplos domínios Gcbox, potencialmente reconhecidos pelos fatores de transcrição $S p 1^{80}$. Existem evidëncias mostrando que a expressão do gene da galectina-3 humano e murino são regulados por mecanismos epigenéticos. Foi observado que a metilação está envolvida na regulação da expressão do gene da galectina-3 em alguns tumores da pituitária, em 
linhagens de carcinoma humano de mama, de tireóide ${ }^{81}$ e em linhagens de melanoma murino (Teixeira e col., em preparação).

Além disso, a expressão de galectina-3 pode ser controlada de várias maneiras. A infecção e transformação com vírus de sarcoma murino Kirsten ${ }^{79}$, com vírus linfotrópico T humano tipo 1 (HTLV-1) ${ }^{82}$ ou com vírus da imunodeficiência humana tipo 1 (HIV) ${ }^{83}$ aumentam significantemente a expressão de galectina-3. A atividade do promotor de galectina-3 é aumentada quando fibroblastos são transfectados com o oncogene Ras ${ }^{84}$ ou após o tratamento com PMA ${ }^{84}$, mas é diminuída após a transfecção com o gene supressor de tumor p53 selvagem ${ }^{84}$. Mais recentemente, se verificou que a expressão de galectina-3 em macrófagos estimulados com PMA é inibida por inibidores da proteína quinase $C$ e de MEK1. Nesse trabalho é sugerido o envolvimento da via de sinalização de Ras/MEKK1/MKK1 e da p38 MAPK no aumento da expressão de galectina-3 induzida por PMA ${ }^{85}$.

A galectina-3 é isolada como um monômero, mas se polimeriza formando agregados quando se liga a superfícies contendo glicoconjugados. O seu domínio N-terminal é importante para que isso ocorra, já que a sua deleção causou diminuição da razão de associação da galectina-3 e perda da sua atividade de hemaglutinação ${ }^{86}$. Mais recentemente foi demonstrado que a galectina-3 pode se agregar através do seu domínio carboxi-terminal 87. Assim, a galectina-3 pode ligar-se a pelo menos dois ligantes diferentes, formando uma ponte molecular entre esses dois ligantes. Como todas as outras galectinas, a galectina-3 é definida como uma proteína que se liga a $\beta$-galactosídeos. A adição de um resíduo de glicose a galactose para formar 
lactose (Lac) aumenta a sua afinidade pela galectina-3 consideravelmente 88. A troca de um grupo hidroxil na Lac por um grupo mais hidrofóbico como a acetamida para formar $N$-acetilactosamina (LacNAc) aumenta a afinidade pela galectina-3 mais de 6 vezes, enquanto que a adição de um grupo hidrofílico como um resíduo de Gal ao grupo 3-hidroxil da LacNAc aumenta a afinidade pela galectina-3 em mais de 23 vezes em comparação a Lac (Tabela III). Substituições mais interessantes (ligantes 8-11, Tabela III) foram feitas introduzindo-se grupos hidrofóbicos na posição 3 do resíduo de Gal na LacNAc, aumentando a afinidade pela galectina-3 em até 50 vezes em comparação a LacNAc $^{88}$.

Tabela III. Afinidade de galectina-3 por glicoconjugados. Traduzido de Lukyanov, P. Glycoconjugate Journal 19, 527-535,2004 ${ }^{88}$.

\begin{tabular}{|c|c|c|}
\hline $\mathbf{N}^{\mathbf{O}}$ & Ligantes & Afinidade relativa \\
\hline 1 & Lac & 1.0 \\
\hline 2 & LacNAc & 6.6 \\
\hline 3 & 2'-aFuc-Lac & 3.0 \\
\hline 4 & 3-aGal-LacNAc & 23.3 \\
\hline 5 & 3,6 LacNAc $_{2}-$ Lac & 29.1 \\
\hline 6 & 3-aGalNAc-(2-aFuc)-Gal & 16.7 \\
\hline 7 & 3'-aGalNac-(2'-aFuc)-Lac & 17.3 \\
\hline 8 & 3'-Nac-LacNAc & 11.6 \\
\hline 9 & 3'NBzl-LacNAc & 97.6 \\
\hline 10 & 3'-NSuc-LacNAc & 105.0 \\
\hline 11 & 3'-N(4-MeO-F $\left.{ }_{4}-\mathrm{Bz}\right)$-LacNAc & 311.0 \\
\hline
\end{tabular}

A galectina-3 pode ser encontrada tanto no meio intracelular (núcleo e citoplasma) quanto no meio extracelular. Extracelularmente, a galectina-3 
interage com glicoconjugados presentes na superfície celular bem como com proteínas da matriz extracelular (ECM). A galectina-3 possui grande afinidade pela laminina, interagindo com os resíduos de polilactosaminas presentes na glicoproteína ${ }^{89}$. Na superfície celular, a galectina-3 interage com inúmeros ligantes que estão sumarizados na Tabela IV. Nessas interações, a galectina-3 pode ser encontrada tanto na forma monomérica, bem como formando oligômeros, quando está em altas concentrações e se liga a glicoconjugados multivalentes ${ }^{69,90}$. Dessa maneira, a galectina-3 pode formar complexos quando se liga a glicoconjugados multivalentes, assim como as treliças formadas por anticorpos e antígenos multivalentes ${ }^{91}$, podendo promover a ligação cruzada entre glicoconjugados da superfície celular e desencadear a ativação de várias vias de sinalização. Conseqüentemente, a galectina-3 pode modular vários processos biológicos, entre eles: progressão no ciclo celular, apoptose, adesão e migração.

Intracelularmente, a galectina-3 é transportada entre o núcleo e o citoplasma, sendo importante em processos como o splicing de RNA, regulação da proliferação e da apoptose ${ }^{92-94}$

Outras atividades da galectina-3 parecem envolver interações carboidrato-independentes, já que a galectina-3 interage com proteínas intracelulares como $\beta$-catenina ${ }^{95}$, sinexina ${ }^{96}$ e K-RAS ${ }^{97}$.

Tabela IV. Ligantes de galectina-3. Traduzido de Lukyanov, P. Glycoconjugate Journal 19, $527-535,2004^{88}$. 


\begin{tabular}{|c|c|}
\hline Ligantes & Funções associadas \\
\hline Laminina & Modulação da adesão célula-matriz \\
\hline Colágeno IV & Modulação da adesão célula-matriz \\
\hline Fibronectina, vitronectina & Modulação da adesão célula-matriz \\
\hline Hensina & Diferenciação terminal de células epiteliais \\
\hline Elastina & Adesão celular a elastina \\
\hline Mac-2BP (gp 90) & Adesão célula-célula e célula-matriz \\
\hline Cubilina & Adesão e endocitose \\
\hline MP 20 & Adesão célula-matriz \\
\hline Mucinas & Adesão célula-célula e célula-matriz \\
\hline $\begin{array}{l}\text { Antígeno carcino- } \\
\text { embrionário (CEA) }\end{array}$ & Adesão célula-célula e célula-matriz \\
\hline $\begin{array}{l}\text { Produtos terminais da } \\
\text { glicosilação avançada } \\
\text { (AGE) }\end{array}$ & Medeia a endocitose de AGEs \\
\hline$\alpha 1 \beta 1$ integrinas & Adesão célula-célula e célula-matriz \\
\hline $\begin{array}{l}\alpha \mathrm{M} \beta 1 \text { (antígeno Mac-1 em } \\
\text { macrófagos humanos) }\end{array}$ & Adesão célula-célula e célula-matriz \\
\hline $\begin{array}{l}\text { CD66a/CD66b (neutrófilos } \\
\text { humanos) }\end{array}$ & $\begin{array}{l}\text { Induz a ativação da NADH oxidase } \\
\text { adesão das células a ECM }\end{array}$ \\
\hline CD98 (células jurkat) & $\begin{array}{l}\text { Induz o recrutamento do } \mathrm{Ca}^{2+} \text { extracelular } \\
\text { e modula a adesão célula-célula e célula- } \\
\text { matriz }\end{array}$ \\
\hline $\mathrm{CD}^{+} / \mathrm{CD}^{+}$(linfócitos T) & $\begin{array}{l}\text { Inibe a apoptose e modula a adesão } \\
\text { célula-célula e célula-matriz }\end{array}$ \\
\hline $\begin{array}{l}\text { FcgRII (células leucêmicas } \\
\text { de eosinófilos humanos) }\end{array}$ & Diminuição da expressão do gene de IL-5 \\
\hline $\begin{array}{l}\text { NCA-160 (neutrófilos } \\
\text { humanos) }\end{array}$ & Induz o burs" oxidativo em neutrófilos \\
\hline NCAM & Adesão célula-célula e célula-matriz \\
\hline $\begin{array}{l}\text { IgE (células leucêmicas de } \\
\text { basófilos humanos) }\end{array}$ & $\begin{array}{l}\text { Desencadeia a degranulação e a } \\
\text { liberação de serotonina }\end{array}$ \\
\hline $\begin{array}{l}\text { Lamp-1, Lamp-2 (células } \\
\text { tumorais) }\end{array}$ & Adesão célula-célula e célula-matriz \\
\hline LPS & $\begin{array}{c}\text { Adesão de patógenos a matriz e células } \\
\text { do hospedeiro }\end{array}$ \\
\hline$\beta$-catenina & Regulação da sinalização Wnt- $\beta$-catenina \\
\hline
\end{tabular}


A galectina-3 é encontrada em fibroblastos, macrófagos ativados, basófilos e mastócitos ${ }^{78,98-100}$, em algumas células epiteliais (por exemplo, em rim e intestino) ${ }^{101,102}$ e em alguns neurônios sensoriais ${ }^{103}$.

A galectina-3 pode ser fosforilada nos resíduos de serina localizados nas posições 6 e 12 da porção N-terminal. Os resíduos ácidos localizados em ambos os lados do resíduo de $\operatorname{Ser}^{6}$ tornam a molécula de galectina-3 em um ótimo substrato para a enzima caseína quinase I e II ${ }^{104}$. A função precisa da fosforilação da galectina-3 e o seu papel na determinação da interação da galectina-3 com seus ligantes não foram ainda esclarecidos. Existem evidências mostrando que a fosforilação do resíduo de $\operatorname{Ser}^{6}$ diminui em até 85\% a ligação da galectina-3 a laminina-1 e à mucina do câncer de cólon. Quando a proteína é desfosforilada pela enzima fosfatase tipo I, ela tem a interação com seus ligantes restaurada ${ }^{105}$. Há evidências que sugerem um possível papel das fosfatases na modulação das interações célula-célula e célula-matriz ${ }^{106}$.

A galectina-3 é sintetizada pelos ribossomos livres no citoplasma e o mecanismo pelo qual ela é direcionada para diferentes compartimentos celulares ou é secretada para o meio extracelular não é conhecido, já que esta não possui peptídeo sinal. Análises de pulso e caça, revelaram que a secreção de galectina-3 pelas MDCK II (células epiteliais de rim de cachorro) é feita de maneira polarizada e que não é inibida pela brefeldina A ou pela monensina, drogas que inibem o transporte através do complexo retículogolgi, indicando que a galectina-3 não é secretada pelo mecanismo clássico 107. 
Existem evidências de que a porção N-terminal da galectina-3 esteja envolvida no seu endereçamento e que essa atividade não seja dependente da fosforilação do resíduo de $\operatorname{Ser}^{6}$ pela caseína quinase I. A deleção da porção N-terminal resultou em alteração na compartimentalização e na função da galectina-3. Nas células que expressam a proteína truncada, sem o domínio amino-terminal, a galectina-3 está localizada preferencialmente no citoplasma, não sendo encontrada no núcleo, na superfície celular ou sendo secretada. Ainda, a galectina-3 mutada também perde a sua capacidade de se ligar a asialofetuína, já que não foi possível purificá-la numa coluna de afinidade. Isso sugere que a proteína truncada foi dobrada incorretamente, não expondo, dessa maneira, seu domínio de reconhecimento de carboidratos, localizado na porção carboxi-terminal ${ }^{86,87}$.

Sabe-se que apesar da secreção de galectina-3 ser normal pelas células em meio com soro, ela é dramaticamente reduzida quando este é retirado do meio. A fetuína, uma glicoproteína sérica abundante no soro fetal, quando adicionada ao meio privado de soro em concentrações similares àquela suplementada com $10 \%$ de SFB é capaz de estimular a secreção de galectina-3 de células de carcinoma de mama ${ }^{108}$.

A expressão de galectina-3 é modulada durante a diferenciação celular e durante o desenvolvimento dos órgãos e tecidos, e está alterada em algumas condições fisiopatológicas como a inflamação e a progressão tumoral.

A galectina-3 se liga a lgE e desencadeia a ativação de basófilos e mastócitos, o que sugere seu papel na reação alérgica ${ }^{99,100}$. Evidências 
mais recentes mostraram que a galectina-3 inibe especificamente a transcrição de IL-5, mas não de IL-4, em eosinófilos humanos ${ }^{109}$. Esta observação sugere que a galectina-3 possa ser importante na resposta imune do tipo Th-2.

Galectina-3 induz a ativação de várias células inflamatórias e age como uma molécula pró-inflamatória. Existem evidências de que a galectina3 ative a NADPH oxidase e estimule a produção de ânion superóxido em neutrófilos 110,111. A galectina-3 também pode funcionar como uma quimiocina, atraindo monócitos e macrófagos ${ }^{112}$. De acordo com esses resultados in vitro, estão dados que mostram que animais nulizigotos para o gene da galectina-3 exibiram significante redução da resposta inflamatória em modelos de inflamação peritonial ${ }^{113,114}$ e do trato respiratório ${ }^{115}$. No modelo de inflamação peritonial também se observou níveis reduzidos da atividade de NFkB, um fator de transcrição ativado durante a inflamação, em animais nulizigotos para o gene da galectina-3.

\section{GALECTINA-3 NA PROGRESSÃO TUMORAL}

No processo de transformação celular, a expressão de galectina-3 encontra-se alterada em alguns sistemas, sendo um eficiente marcador para alguns tumores humanos ${ }^{116-118}$. Em alguns casos, pode-se observar uma relação direta entre o aumento nos níveis de expressão da galectina-3 e a aquisição de um fenótipo mais agressivo. Nessas situações, o aumento da expressão de galectina-3 poderia estar modulando vários eventos que ocorrem durante o processo de transformação maligna, entre eles: aumento da proliferação celular, resistência ao anoikis (processo de apoptose 
induzido quando as células perdem a interação com a sua matriz extracelular - morte por desalojamento: an, sem; oikis, casa) e a apoptose induzida por drogas quimioterápicas, aumento da motilidade celular e da invasão de células através da matriz extracelular e angiogênese. No entanto, em alguns casos, observa-se diminuição da expressão de galectina-3. É importante notar que a mudança na localização subcelular da galectina-3 (por exemplo, do núcleo para o citoplasma) também acompanha a transformação de uma célula normal ${ }^{119,120}$.

A concentração sérica de galectina-3 foi determinada em pacientes com vários tipos de câncer. Comparando-se os níveis de galectina-3 no soro de indivíduos saudáveis, observou-se aumento significativo em pacientes com câncer de mama, pulmão, ovário, câncer gastrointestinal, melanoma e linfoma não Hodgkin. Além disso, a concentração de galectina-3 no soro de pacientes que apresentavam metástase era bem maior que em pacientes onde o tumor era localizado ${ }^{121}$. Contudo, neste estudo não se determinou qual ou quais tipos celulares foram responsáveis pelas variações no nível sérico de galectina-3.

Células de carcinoma de mama humano que não expressam galectina-3, não são tumorigênicas e são pouco metastáticas ou metastáticas somente em camundongos atímicos. Quando essas células passam a expressar galectina-3, elas adquirem a capacidade de crescer independentemente de ancoragem e se tornam tumorigênicas. Da mesma maneira, outra linhagem de células de carcinoma de mama (MDA-MB-435) quando têm a expressão de galectina-3 inibida, apresenta reversão do 
fenótipo transformado. Entretanto, os níveis de expressão de galectina-3 em carcinomas de mama humano são inversamente correlacionados com o aumento da agressividade desses tumores ${ }^{122,123,123}$.

Células de carcinoma papilar de tireóide também perdem as características de uma célula transformada em cultura após a inibição da expressão de galectina-3 ${ }^{124}$. Inversamente, a transfecção de galectina-3 em células de tiróide normal induz o fenótipo transformado ${ }^{125}$. In vivo também observa-se o aumento da expressão de galectina-3 em carcinomas de tireóide em comparação com as células do tecido normal e de tumores benignos ${ }^{126}$.

O mecanismo envolvido na transformação maligna induzida pela galectina-3 não é totalmente conhecido, mas existem evidências da interação entre o oncogene Ras e a galectina-3 ${ }^{127}$. Tumores humanos freqüentemente possuem mutações no oncogene Ras, que o tornam constitutivamente ativo, e as proteínas mais comumente afetadas são HRAS, KRAS e NRAS. As proteínas Ras contribuem em vários aspectos do fenótipo maligno e sua atividade requer a sua translocação e ancoragem na membrana plasmática. Evidências experimentais mostraram que a galectina3 se liga preferencialmente à proteína KRAS e promove a ativação de RAF1 e de PI3K, contribuindo para a ativação de cascatas de sinalização e a regulação da expressão de alguns genes ${ }^{127}$. Esses dados sugerem 0 envolvimento de galectina-3 na ancoragem de RAS a membrana plasmática e na transformação mediada por RAS. 
De fato, algumas funções de galectina-3, são pelo menos em parte, resultado da ativação de KRAS, já que o aumento da proliferação celular, do crescimento independente de ancoragem e da atividade anti-apoptótica de galectina-3 envolve a via de sinalização KRAS/MEK ${ }^{128}$.

A atividade anti-apoptótica de galectina-3 também pode desempenhar papel fundamental na sua contribuição para a aquisição do fenótipo transformado. Células tumorais que expressam galectina-3 são mais resistentes a apoptose induzida por vários estímulos, entre eles: óxido nítrico ${ }^{129}$, genisteína ${ }^{92}$, e drogas quimioterápicas ${ }^{130}$

A atividade anti-apoptótica de galectina-3 não é totalmente conhecida, mas existem dados mostrando que após um estímulo apoptótico, a galectina-3 é translocada do citoplasma ou do núcleo para a mitocôndria ${ }^{96}$. Na mitocôndria, a galectina-3 inibe a liberação de citocromo c e bloqueia alterações do potencial de membrana mitocondrial, prevenindo, dessa maneira, a apoptose ${ }^{131}$. Também foi mostrado que a atividade antiapoptótica da galectina-3 é regulada pela fosforilação dos resíduos de $\operatorname{Ser}^{6}$ 132 pela caseína quinase I. Além disso, a fosforilação é necessária para a exportação da galectina-3 do núcleo após estímulo apoptótico ${ }^{130}$.

Apesar de a galectina-3 não pertencer à família do oncogene antiapoptóptico $B C L-2$, ela contém os mesmos quatro aminoácidos do motif (NWGR) conservado no domínio BH1 desta família ${ }^{133}$. Foi mostrado que a substituição do resíduo de Gly 182 pelo de Ala no motif NWGR aboliu a atividade anti-apoptótica da galectina-3, demonstrando que este motif é essencial para a atividade anti-apoptótica da galectina-3, como o é para 
proteínas da família de BCL-2. BCL-2 pode se ligar a galectina-3, e esta interação é inibida por lactose. No entanto, não se sabe se existe interação direta entre as 2 proteínas e sua associação intracelular não foi estabelecida 134.

Vários trabalhos mostram o envolvimento de galectina-3 no controle da proliferação de células tumorais. A inibição da expressão de galectina-3 em células de carcinoma de mama e em células de carcinoma de tireóide resultou no crescimento mais lento dessas células in vivo ${ }^{124,135}$. No entanto, quando a linhagem de carcinoma de próstata LNCaP passou a expressar galectina-3, esta passou a crescer mais devagar do que as células controle tanto in vitro quanto in vivo ${ }^{136}$. Recentemente, o efeito aparentemente contraditório de galectina-3 na proliferação de células tumorais foi esclarecido. Observou-se que quando a galectina-3 está localizada no citossol das células LNCaP, estas apresentam aumento da capacidade de crescimento independente de ancoragem in vitro e aumento do crescimento tumoral in vivo, enquanto aquelas que expressam a proteína no núcleo crescem mais devagar ${ }^{137}$. Esses resultados indicam que o efeito da galectina-3 no crescimento das células tumorais depende da localização subcelular da proteína.

Também existem evidências do envolvimento de galectina-3 no controle do ciclo celular. A galectina-3 diminui a expressão das ciclinas E e A, enquanto aumenta a expressão dos inibidores p21 e p27 em células de carcinoma de mama ${ }^{138}$. Mais recentemente, foi demonstrado que a 
galectina-3 ativa o promotor de ciclina D1 devido a sua interação com $\beta$ catenina ${ }^{95,139}$.

Devido a sua capacidade de formar dímeros e/ou oligômeros, a galectina-3 pode formar uma ponte entre as células tumorais (adesão homotípica) ou entre as células tumorais e o endotélio (adesão heterotípica). De fato, foi mostrada a participação de galectina-3 na adesão homotípica de células tumorais de mama e de próstata, indicado pela presença de clusters de galectina-3 nos sítios de adesão célula-célula ${ }^{140}$. Além disso, células de carcinoma de mama altamente metastáticas expressam altos níveis de galectina-3 e possuem maior capacidade de se ligar a camadas de células endoteliais in vitro comparado com a sua contraparte normal. O envolvimento de galectina-3 nesse processo foi confirmado pela sua inibição após o tratamento das células com lactulosyl-L-leucina, antagonista sintético do antígeno T, que se liga a galectina-3 por mimetizá-lo ${ }^{141}$.

A participação de galectina-3 na migração e invasão celular tem sido confirmada por vários autores. Células K7M2 e K12 são linhagens derivadas de osteosarcoma murino e apresentam potencial metastático diferente. Análises de microarray mostraram que as células $k 7 M 2$, que são mais metastáticas, expressam mais galectina-3 que as células $\mathrm{K} 12$, que são menos metastáticas ${ }^{142}$. No entanto, não se sabe se existe associação entre a expressão de galectina-3 e a maior capacidade metastática dessas células. A adição de galectina-3 exógena a células de carcinoma de mama aumentou a sua capacidade migratória em matrigel ${ }^{143}$, enquanto que 0 aumento da expressão de galectina-3 em células de carcinoma de pulmão 
aumentou a sua motilidade celular e invasão in vitro ${ }^{144}$. Por outro lado, a adição de galectina-3 exógena diminui a migração de linhagens de carcinoma de cólon humano ${ }^{145}$ e a inibição da expressão de galectina-3 em linhagens de glioblastomas aumentou o seu potencial migratório em laminina-1 ${ }^{146}$. As razões desses resultados contraditórios não estão esclarecidas, mas poderia ser devido aos diferentes receptores reconhecidos pela galectina-3 na superfície das células tumorais, os quais estariam desencadeando diferentes vias de sinalização e conseqüentemente, levando aos diferentes efeitos observados.

Finalmente, existem evidências do envolvimento de galectina-3 na angiogênese. A galectina-3 afeta a quimiotaxia, morfologia e estimula a formação dos tubos capilares de células endoteliais in vitro e participa da angiogênese in vivo ${ }^{147}$. Resultados similares foram documentados nas células de LNCaP que expressam galectina-3 ${ }^{137}$.

\section{GALECTINA-3 COMO UMA MOLÉCULA DE DE-ADESÃO}

Nós observamos que a galectina-3 age como um modulador positivo do processo de migração de fibroblastos em superfícies de laminina-1 (Anexo I). A galectina-3 está localizada no lamelipódio das células CCR2 em migração e a adição de lactose inibe a migração dessas células em laminina-1. Células de sarcoma que expressam galectina-3 são mais migratórias em superfície de laminina-1 do que as células dos animais nulizigotos para o gene da galectina-3. Porém, os mecanismos pelo quais a galectina-3 medeia o processo de migração celular não são conhecidos. 
Embora haja dúvidas quanto à dinâmica de de-adesão, ou ainda, se ela é ativa ou passiva, um crescente número de proteínas tem sido funcionalmente identificado como moléculas de de-adesão. As integrinas são as efetoras dos processos de adesão e migração, no entanto, existem inúmeras moléculas participando desses eventos como agentes modulatórios, entre elas as galectinas ${ }^{148}$.

Foi mostrado que a galectina-3 inibe a interação entre os timócitos e as células epiteliais do timo, acelerando a liberação dos timócitos, dessa maneira, agindo como uma molécula de-adesiva ${ }^{149}$. Ao agir como uma molécula de-adesiva, a galectina-3 poderia estar modulando no nosso sistema, a interação entre as integrinas e laminina-1 e mediando o ciclo de adesão/de-adesão/adesão observado no processo de migração.

Baseado nesses dados, o objetivo do nosso trabalho é avaliar o mecanismo de ação da galectina-3 no processo de migração de fibroblastos transformados em laminina-1. 
OBJETIVOS 


\section{2 - OBJETIVO GERAL}

Avaliação do mecanismo de ação de galectina-3 no aumento da capacidade migratória de células mesenquimais derivadas de sarcomas dos animais nulizigotos para o gene da galectina-3. E identificação do(s) ligante(s) de galectina-3 localizado(s) na superfície celular envolvido(s) no processo de migração celular.

\section{3 - DELINEAMENTO EXPERIMENTAL}

1- Geração da galectina-3 recombinante;

2- Geração de uma galectina-3 híbrida, a qual foi conjugada a fosfatase alcalina. A galectina-3 foi utilizada para detectar a presença e distribuição dos ligantes de galectina-3 através de ensaios imunoenzimáticos como overlay e imunoistoquímica;

3- Análise da estabilidade dos complexos focais das células mesenquimais na presença de galectina-3 exógena;

4- Análise da redistribuição do citoesqueleto das células mesenquimais na presença de galectina-3 exógena;

5- Análise do comportamento de proteínas presentes nos complexos focais como tirosino-quinases, entre elas, FAK e tirosino-fosfatases como SHP2; 
MATERIAIS E MÉTODOS 


\section{4 -MATERIAIS E MÉTODOS}

\section{1 - GERAÇÃO DE GALECTINA-3 RECOMBINANTE}

A galectina-3 recombinante (rgal-3) foi uma ferramenta muito importante na realização deste trabalho, como será descrito a seguir. A geração da rgal-3 compreendeu várias etapas: expressão da proteína a partir do plasmídeo pKK233-2-gal3 transformado na bactéria JM-107, purificação numa coluna de afinidade com beads de lactosyl-Sepharose ${ }^{\circledR}$, diálise contra PBS e concentração no filtro AMICON. Após a confirmação da presença da rgal-3 por western blot, a atividade de ligação da proteína foi avaliada em ensaio de ELISA.

\subsection{1 - EXPRESSÃO DA GALECTINA-3 RECOMBINANTE}

Em nosso laboratório estavam disponíveis dois vetores de expressão contendo o gene da galectina-3 humana: os vetores pQE60-gal 3 (Quiagen), transformado na bactéria XL1blue e o pKK233-2 (Amersham Pharmacia biotech, Buckinghamshire, Inglaterra) transformado na bactéria JM107, ambos gentilmente cedidos pelo Dr. Fu-Tong Liu (Universidade da Califórnia - Davis, Davis, CA). Os dois sistemas foram testados como descrito a seguir para avaliar qual possuía maior rendimento. Após alguns testes, o vetor pKK233-2 apresentou maior rendimento (maior concentração de proteína/mL) e foi escolhido para ser usado na geração da rgal-3.

Uma colônia da bactéria JM107 foi inoculada em $4 \mathrm{~mL}$ de meio LB líquido (Triptona 1\%, Extrato de Levedura 0,5\% e $\mathrm{NaCl}$ 0,5\%) acrescido de ampicilina (100 $\mu \mathrm{g} / \mathrm{mL}$ ) (GIBCO BRL, Grand Island NY) e colocado em 
agitador orbital por $16 \mathrm{~h}$ a $37^{\circ} \mathrm{C}$ para expansão da colônia. Em seguida, a cultura saturada foi diluída 1:50 em meio 2YT líquido (Triptona 1,6\%, Extrato de Levedura 0,5\%e $\mathrm{NaCl} 0,5 \%$ ) e expandida por aproximadamente $3 \mathrm{~h}$, até alcançar a $A_{600}=0,8$ (fase log de crescimento), quando foi adicionado 0 IPTG (isopropil-tio- $\beta$-D-galactosídeo) (Pharmacia) $500 \mu \mathrm{M}$ para indução da transcrição do gene da galectina-3. A cultura foi então centrifugada a 1500 $x g$ por 30 min a $4^{\circ} \mathrm{C}$ e os pellets congelados.

No dia seguinte, os pellets foram ressuspendidos em $20 \mathrm{~mL}$ de PBS (tampão fosfato salina) acrescido dos inibidores de protease fenilmetilsulfonilfluoreto (PMSF) $1 \mathrm{mM}$; aprotinina $2 \mu \mathrm{g} / \mathrm{mL}$ e leupeptina $1 \mathrm{mM}$ e as bactérias foram lisadas no French Cell Press (SIM AMINCO- Spectronic Instruments) a 1500 psi. Em seguida, o lisado foi centrifugado a 5000 xg por 10 min e o sobrenadante recolhido para ser purificado na coluna de afinidade.

\subsection{2 - PURIFICAÇÃO DA rGAL-3 EM COLUNA DE AFINIDADE}

Sabe-se que a galectina-3 tem afinidade por $\beta$-galactosídeos ${ }^{71}$, por esta razão foi utilizada uma coluna de afinidade com beads de lactosylSepharose $^{\circledR}$ (Sigma, St. Louis, Minessota) para purificá-la. O sobrenadante recolhido a partir do extrato bacteriano foi transferido e passado pela coluna de lactosyl-Sepharose ${ }^{\circledR}$ por 3 vezes. Em seguida, os beads foram lavados com $10 \mathrm{~mL}$ de TEN (Tris 1M, EDTA 5mM, NaCl 150 mM) 2 vezes e com 10 $\mathrm{mL}$ de PBS 2 vezes para retirar o material que se ligou inespecificamente. A galectina-3 então foi eluída da coluna com $10 \mathrm{~mL}$ de uma solução de 
Lactose 250 mM (D-Gal- $\beta 1 \rightarrow 4-D-G l c)$ (Sigma, St. Louis, Minessota) em PBS e guardada a $4^{\circ} \mathrm{C}$ para posterior diálise. Ao final da purificação, os beads foram lavados com PBS e TEN e estocados em PBS-azida 0,1\% a $4^{\circ} \mathrm{C}$. Todo o procedimento foi realizado a $4^{\circ} \mathrm{C}$.

\subsection{3 - DIÁLISE DO MATERIAL PURIFICADO}

A diálise convencional separa pequenas moléculas das grandes moléculas por permitir somente a difusão das pequenas moléculas através da membrana com permeabilidade seletiva. A membrana de diálise (Sigma, St. Louis, Minessota) utilizada possuía 12 KDa de cut off, ou seja, moléculas com massa molecular menor que $12 \mathrm{KDa}$ difundiram através dos poros da membrana, enquanto moléculas com massa molecular acima de 12 KDa foram retidas. Como a galectina-3 possuí aproximadamente $35 \mathrm{KDa}$ de massa molecular ${ }^{71}$ esta foi retida, enquanto a lactose difundiu através da membrana. O material purificado foi dialisado contra 2,0 L de PBS 3 vezes, por $4 \mathrm{~h}$ cada. Ao mesmo tempo em que ocorreu o movimento do soluto (lactose) através da membrana, também ocorreu o movimento do solvente (PBS) na direção oposta, resultando em uma amostra diluída. Por esta razão, a amostra contendo a proteína rgal-3 foi concentrada em seguida.

\subsection{4- CONCENTRAÇÃO DA GALECTINA-3 RECOMBINANTE}

O aparato utilizado para concentrar a rgal-3 foi o filtro de centrifugação Amicon Ultra-15 (Millipore, Carrigtwahill) com cut off de 10 KDa. Este aparato é constituído por um tubo de centrífuga e um filtro (onde 
fica retida a amostra concentrada). Como a membrana do aparato possui glicerol e este interfere com os reagentes do kit de dosagem protéica, a membrana foi pré-lavada 1 vez com PBS, 1 vez com $\mathrm{NaOH} \mathrm{0,1} \mathrm{N} \mathrm{e} \mathrm{em}$ seguida novamente lavada 3 vezes com PBS. A seguir, $10 \mathrm{~mL}$ da amostra foi colocada no filtro e centrifugada a $4000 \mathrm{xg}$ por 15 min a $4^{\circ} \mathrm{C}$ num rotor móvel. Ao final da concentração a amostra retida no filtro foi retirada cuidadosamente com uma pipeta e estocada a $-20^{\circ} \mathrm{C}$ para ter sua concentração protéica determinada.

\subsection{5 - DOSAGEM PROTÉICA}

A concentração protéica das amostras eluídas foi determinada com o kit DC Protein Assay da Bio-rad (Hercules, CA) que é baseado no método de Folin ${ }^{150}$. O ensaio é baseado na reação de uma proteína com uma solução de tartarato de cobre seguida da redução do reagente de Folin pela proteína tratada com o cobre em meio alcalino. O desenvolvimento da cor é devido aos aminoácidos tirosina e triptofano e em menor extensão pela cisteína e histidina.

A proteína reduz o reagente de Folin pela perda de 1, 2 ou 3 átomos de oxigênio.Numa placa de 96 poços, são colocados $4 \mu$ de cada amostra a ter sua concentração protéica determinada, $20 \mu$ da solução de tartarato de cobre e $160 \mu$ do reagente de Folin. A placa é homogeneizada vagarosamente para evitar a formação de bolhas e após 15 min sua absorbância a 655 nm é determinada e comparada às obtidas em curva padrão de BSA $(0-1,44 \mu \mathrm{g})$. 


\subsection{6 - WESTERN BLOTTING}

As amostras eluídas foram separadas por eletroforese em gel de poliacrilamida segundo o protocolo de LaemmLi em condições redutoras a $4^{\circ} \mathrm{C}{ }^{151}$ e sob uma voltagem constante de $100 \mathrm{~V}$. O gel de corrida foi preparado com Tris $0,375 \mathrm{M} \mathrm{pH} 8,8$, SDS 0,1\%, acrilamida 12,5\%, persulfato de amônio (APS) 0,03\% e N,N,N,N tetra metiletilenodiamina (TEMED, Sigma); e o gel de empilhamento, com Tris 0,125 M pH 6,8, SDS 0,1\%, acrilamida 4\%, APS 0,045\%, e TEMED. Os extratos protéicos foram diluídos em tampão de amostra redutor (Tris- $\mathrm{HCl} 240$ mM pH 6,8, SDS 0,8\%, $\beta$ mercaptoetanol $200 \mathrm{mM}$, glicerol 40\% e azul de bromofenol 0,02\% ). A eletroforese foi feita em tampão Tris $25 \mathrm{mM}$, glicina $0,19 \mathrm{M} \mathrm{pH} \mathrm{8,3,} \mathrm{SDS}$ 0,1\% à temperatura ambiente e sob uma voltagem constante de $100 \mathrm{~V}$.

Em seguida, os extratos protéicos separados no gel de poliacrilamidaSDS foram corados com solução de Coomassie Blue ou eletroforeticamente transferidos para membrana de PVDF (Hydrophobic polyvinylidene difluoride, Amersham, Buckinghamshire, Inglaterra). A transferência foi feita em tampão Tris 25mM, glicina 192 mM, metanol 20\% por duas h a $150 \mathrm{~V}$ a $4^{\circ} \mathrm{C}$.

Para bloquear os sítios inespecíficos, a membrana foi incubada em leite desnatado Molico (Nestlè) 5\% em PBS por $1 \mathrm{~h}$ a temperatura ambiente. Depois de lavada 3 vezes com PBS por 10 min, a membrana foi incubada por $16 \mathrm{~h} \mathrm{a} 4^{\circ} \mathrm{C}$ com o anticorpo monoclonal anti-galectina-3 M3/38 (ATCC), novamente lavada com leite Molico em PBS 3 vezes por 10 min e incubada com o anticorpo secundário anti-IgG de rato conjugado a peroxidase (HRP — 
horseradish peroxidase conjugate) $(0,5 \mu \mathrm{g} / \mathrm{mL})(\mathrm{KPL}$ - Kirkegaard \&Perry Laboratories, Maryland, USA) diluído em leite Molico/PBS, por $1 \mathrm{~h}$ a temperatura ambiente. A membrana foi revelada com $7,5 \mathrm{~mL}$ de uma solução de Tris-HCL 0,05\% pH 7, 8, NaCl 150mM, $10 \mu \mathrm{lde} \mathrm{H}_{2} \mathrm{O}_{2}$ e $3.75 \mathrm{mg}$ de DAB (3,3-Tetrahidrocloro Diaminobenzidina - Sigma, St. Louis, MO). A reação foi interrompida pela imersão da membrana em água destilada após o aparecimento das bandas.

\section{2- CONSTRUÇÃO E GERAÇÃO DA GALECTINA-3 CONJUGADA A FOSFATASE ALCALINA}

Com o objetivo de criar uma ferramenta útil no na identificação dos ligantes de galectina-3 e no diagnóstico e prognóstico de tumores, foi construída uma proteína quimérica, a galectina-3 conjugada a fosfatase alcalina (Gal-3/FA). Além disso, a Gal-3/FA foi utilizada como sonda em ensaios de overlay. A construção e geração da Gal-3/FA foram feitas em colaboração com a Dra. Ana Maria Moura da Silva e com o Dr. Diego Butera do Departamento de Imunopatologia do Instituto Butantan.

O vetor de fusão utilizado foi o pLIP6-GN ${ }^{152}$ que permite a expressão periplasmática de proteínas exógenas em fusão com uma variante de fosfatase alcalina de E. coli (APv). Esta versão da APv apresenta 2 mutações nos resíduos 153 e 330 que the conferem aumento de 10 vezes na atividade catalítica. Este vetor está sobre o controle transcricional do promotor sintético tac, sendo induzido por IPTG, e do repressor lacl ${ }^{q}$. O vetor pLIP6-GN tem 6448 pb e apresenta uma única opção de clonagem nos sítios Sfil e Notl localizados entre os códons +6 e +7 do gene da fosfatase alcalina, 
onde é inserido o gene de interesse. A clonagem nesta região permite a restituição do gene $P h o A$, o qual se encontra fora de fase de leitura no pLIP6-GN selvagem. Isso possibilita a triagem de colônias azuis positivas em placas de L-Agar contendo o substrato cromógeno da fosfatase alcalina BCIP (bromo-cloro-indolylfosfato). Os plasmídeos também possuem o gene da $\beta$-lactamase, conferindo resistência a ampicilina e permitindo o crescimento seletivo de E. coli. A Figura 5 mostra o mapa de restrição do vetor pLIP6-GN com os sítios de clonagem indicados pelas setas e a Figura 6 mostra a estratégia de clonagem, mostrando a restituição da fase de leitura do gene PhoA. 


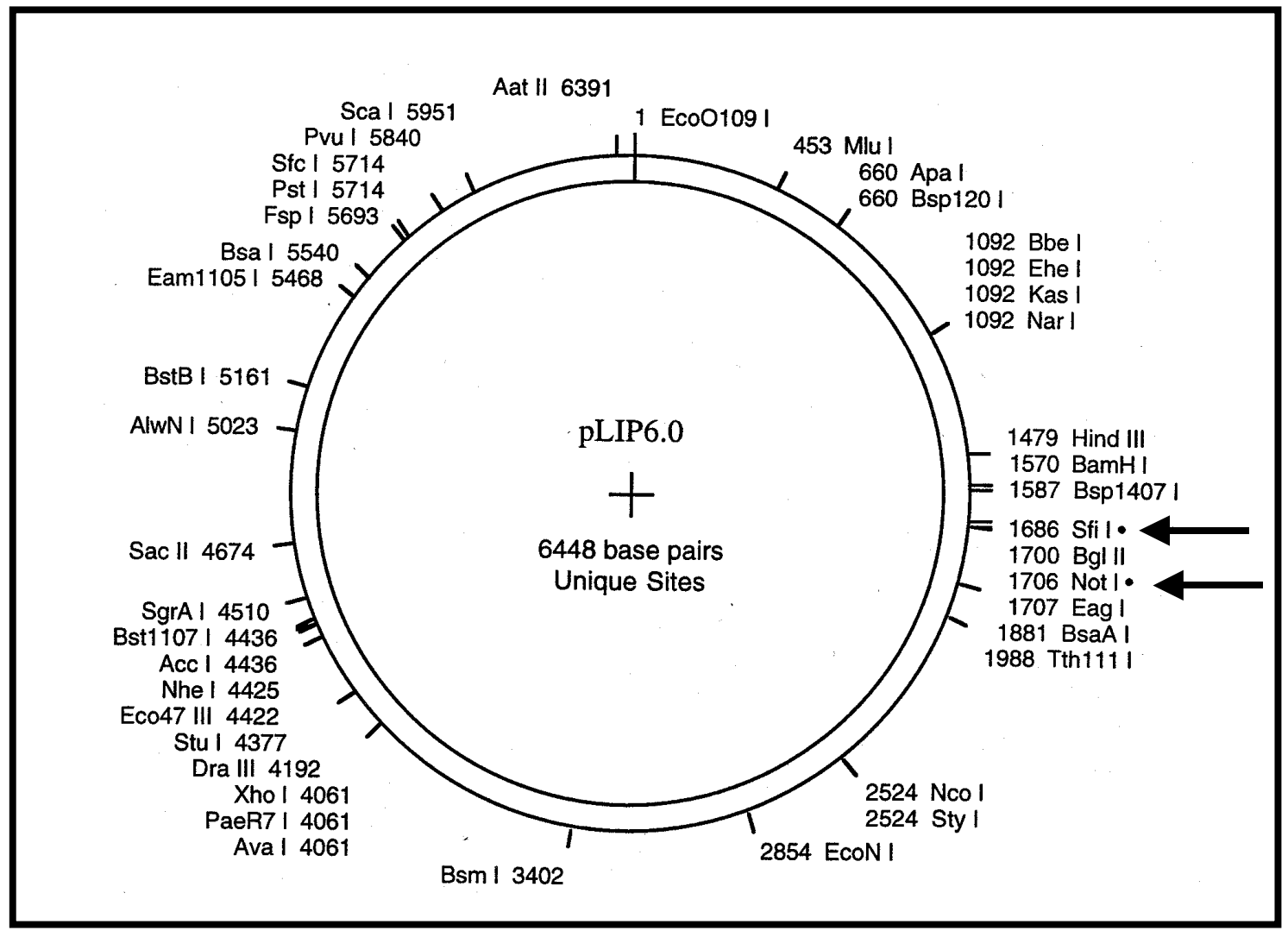

FIGURA 5. Mapa de restrição do vetor pLIP-6-GN com os sítios de clonagem para Sfil e Notl, onde foi inserido o gene da galectina-3 (indicado pelas setas)

$\mathrm{Na}$ representação da estratégia de clonagem podemos observar que antes da clonagem o gene PhoA da fosfatase alcalina está fora da fase de leitura originando uma proteína truncada de 37 resíduos. Após a clonagem de $3 n$ pares de bases (em vermelho) o gene PhoA restabelece sua fase de leitura dando origem a fosfatase alcalina de E. coli (amarelo). Em azul estão representados os sítios de restrição para Sfil e Notl. 
A) Gene PhoA antes da clonagem:

Sfi I

Not I

cggacaccagaaatgccGGCCCAGCCGGCCaagatctG CG GCCGCagttctggaaaa.......aacgggtga

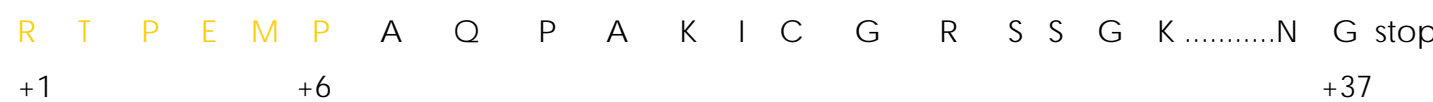

Gene PhoA após a clonagem:

inserto

cggacaccagaaatgccGGCCCAGCCGGCC nnnGCGGCCGCagttctggaaaaccgg.......ctgaaataa

$\begin{array}{lllllllllllllll}R & T & P & E & M & P & A & Q & P & A & X & A & A & A\end{array}$

$\begin{array}{lllll}+1 & +6 & +7 & +450\end{array}$

FIGURA 6. Estratégia de clonagem, mostrando a restituição da fase de leitura do gene $P h o A$ após a clonagem do gene da galectina-3

\subsection{1- CONSTRUÇÃO DOS INICIADORES}

Foram construídos os iniciadores descritos a seguir para clonar o gene de interesse entre os códons +6 e +7 do gene da fosfatase alcalina, onde estão os sítios de restrição para as enzimas Sfil e Not I (New England Biolabs, Beverly, MA):

Primer senso:

Bases de apoio

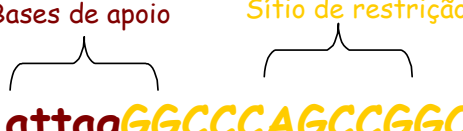

nucleotídeos galectina-3 attag GGCCCAGCCG GC gcagacaatttttcg

Primer antisenso: gagag $G C G G C C G C$ tatcatggtatatga

\subsection{2 - REAÇÃO DE POLIMERASE EM CADEIA (PCR)}


A reação de polimerase em cadeia (PCR) é um método que permite a amplificação in vitro de segmentos de DNA, usando-se dois iniciadores que hibridem com as fitas opostas. Esta PCR foi realizada para inserir o gene da galectina-3 no vetor pLIP6-GN, que contém o gene da fosfatase alcalina.

A reação de PCR incluiu um ciclo inicial de denaturação de $94^{\circ} \mathrm{C}$ por 2 min, seguido por 30 ciclos de amplificação constituídos de 3 etapas:

- A denaturação, onde as fitas de DNA molde se apresentem como fita simples e sem estruturas secundárias. Essa etapa ocorreu a $94^{\circ} \mathrm{C}$ durante 1 $\min$;

-O anelamento, que permite que as sondas hibridem com o molde. Essa etapa ocorreu a $55^{\circ} \mathrm{C}$ e durou $1 \mathrm{~min}$;

-A extensão, onde são sintetizadas as novas fitas de DNA. Essa etapa ocorreu a $68^{\circ} \mathrm{C}$ e durou 2 min;

Para finalizar, foi feito mais um ciclo de extensão final a $68^{\circ} \mathrm{C}$ durante $5 \min$.

O DNA utilizado foi o plasmídeo pkk322-2 que contém o gene da galectina-3. O DNA foi amplificado na presença de 20 pmoles dos iniciadores, 1,25 mM de cada um dos desoxiribonucleotídeos trifosfatos, 1,0 $\mathrm{mM}$ de $\mathrm{MgCl}_{2}, 1$ unidade da enzima Taq polimerase, 20mM de Tris- $\mathrm{HCl}$ pH8.4, 50mM de KCl (tampão da PCR) (INVITROGEN, Carslbad, CA), em volume final de $20 \mu \mathrm{l}$.

Em seguida, os produtos obtidos foram analisados em gel de agarose 1,5\% em tampão de eletroforese TBE (Tris 90 mM, ácido bórico 90 
mM, EDTA 50 mM, pH 8,0) na presença de brometo de etídeo e o tamanho das bandas foi observado.

Os produtos da reação de PCR foram purificados com o Kit Concert Nucleic Acid Purification System (GIBCO BRL, Gaitherburg, MD). Esse sistema permite a rápida purificação dos fragmentos de DNA. Este sistema é baseado na habilidade do DNA de se ligar à membrana de sílica na presença de sais caotrópicos. Após a amplificação do DNA por PCR, os fragmentos foram misturados com a solução de ligação à membrana (guanidina isoticionato). Após a lavagem do DNA isolado, o DNA foi eluído com água. Além disso, o produto da PCR também foi incubado com a enzima Dpnl (New England Biolabs, Beverly, MA) por $1 \mathrm{~h}$ a $37^{\circ} \mathrm{C}$ para digestão do DNA metilado que corresponde ao plasmídeo.

\subsection{3 - DIGESTÃO COM ENZIMAS DE RESTRIÇÃO}

Após a purificação, o produto da PCR e o vetor pLIP6-GN foram digeridos com as enzimas de restrição Sfil e Notl, as quais foram purificadas de E. coli e reconhecem seqüências de bases específicas na dupla hélice de DNA e clivam ambas as fitas da hélice nesse sítio. Na reação de digestão foi usado 5,0 $\mu \mathrm{l}$ de cada enzima por $4 \mathrm{~h}$ a $37^{\circ} \mathrm{C}$ na presença do tampão apropriado. Esta reação de digestão foi realizada para gerar as extremidades coesivas que foram ligadas a seguir. 


\subsection{4 - REAÇÃO DE LIGAÇÃO}

A reação de ligação foi realizada na presença de $1 \mu \mathrm{l}$ da enzima T4 DNA ligase $(5 \mathrm{u} / \mu \mathrm{l}), 1,5 \mu \mathrm{l}$ tampão apropriado, $1 \mu \mathrm{l}$ de ATP $10 \mathrm{mM}$ num volume total de $15 \mu \mathrm{l}$. por $16 \mathrm{~h}$ a $16^{\circ} \mathrm{C}$. O vetor pLIP6-GN e o inserto estavam na proporção molar de 1:5.

\subsection{5 - TRANSFORMAÇÃO DA BACTÉRIA}

Transformamos a bactéria Escherichia coli, cepa BL21 com o produto da reação de ligação (gene da galectina-3 + pLIP6-GN). A bactéria foi estriada em placas de meio LB sólido (Triptona 1\%, Extrato de Levedura $0,5 \%, \mathrm{NaCl} 0,5 \%$ e ágar $1,8 \%$ ) e mantida a $37^{\circ} \mathrm{C}$ por $16 \mathrm{~h}$. No dia seguinte, colônias isoladas foram inoculadas em meio líquido LB acrescido de $10 \mathrm{mM}$ de $\mathrm{MgCl}_{2}$ e $10 \mathrm{mM}$ de $\mathrm{MgSO}_{4}$ e incubadas a $37^{\circ} \mathrm{C}$ sob agitação orbital até o crescimento atingir uma $A_{600}=0,8$ (aproximadamente $3 \mathrm{~h}$ ). Foram centrifugados $10 \mathrm{~mL}$ da cultura por $15 \mathrm{~min}$, a $4000 \mathrm{xg}$ e $4^{\circ} \mathrm{C}$ e as bactérias foram ressuspendidas em $5 \mathrm{~mL}$ de tampão de transformação (10 mM Tris $\mathrm{HCl} \mathrm{pH} \mathrm{8,0,50} \mathrm{mM} \mathrm{CaCl} 2,10 \mathrm{mM} \mathrm{MgSO} 4,10 \mathrm{mM} \mathrm{MgCl}$ ) e mantidas em banho de gelo por $30 \mathrm{~min}$. A seguir centrifugou-se novamente a $4000 \mathrm{xg}$ por 15 min a $4^{\circ} \mathrm{C}$ e ressuspendeu-se em $1 \mathrm{~mL}$ de tampão de transformação. Foram feitas alíquotas de $100 \mu \mathrm{l}$. A cada alíquota foi adicionado em torno de 1-10 ng de DNA e estas foram incubadas em banho de gelo por $30 \mathrm{~min}$. Em seguida os tubos foram colocados a $42^{\circ} \mathrm{C}$ por 5 min e imediatamente recolocados em banho de gelo por 2 min. Aos tubos foi acrescentado $900 \mu \mathrm{l}$ de meio SOC (2\% de peptona, 0,5\% de Extrato de levedura, 0,5\% NaCl, 
2,5\% $\mathrm{MgCl}_{2}, 2 \mathrm{~mL}$ de glicose $1 \mathrm{M}$ ) e estes foram incubados em estufa a $37^{\circ} \mathrm{C}$ por $1 \mathrm{~h}$. Após $1 \mathrm{~h}$, as alíquotas de células com DNA foram plaqueadas (100 $\mu \mathrm{l})$ em meio sólido LB agar fosfato $\left(3,2 \mathrm{~g}\right.$ de $\left.\mathrm{K}_{2} \mathrm{HPO}_{4}\right)$, acrescido de 100 $\mu \mathrm{g} / \mathrm{mL}$ de ampicilina (GIBCO BRL, Grand Istand, NY), 100 mM de IPTG e $50 \mu \mathrm{g} / \mathrm{mL}$ de substrato para fosfatase alcalina (BCIP). O $\quad \mathrm{K}_{2} \mathrm{HPO}_{4}$ foi adicionado ao LB Agar para inibir a fosfatase alcalina bacteriana e o IPTG para induzir a expressão da galectina-3 conjugada a fosfatase alcalina. Como controle fez-se uma estria com as bactérias transformadas com o plasmídeo pLIP6-GN em meio LB Agar fosfato e placas sem bactérias com e sem ampicilina. As placas foram incubadas em estufa a $37^{\circ} \mathrm{C}$ por $16 \mathrm{~h}$. As colônias positivas obtidas apresentavam a coloração azul, resultado da clivagem do BCIP e foram preservadas em meio LB acrescido de $10 \%$ de glicerol e mantidas $\mathrm{a}-70^{\circ} \mathrm{C}$.

\subsection{6 - TRIAGEM DAS COLÔNIAS}

Para analisar as colônias positivas, estas foram inoculadas em 10 $\mathrm{mL}$ de meio liquido LB acrescido de $100 \mu \mathrm{g} / \mathrm{mL}$ de ampicilina e incubadas em estufa com agitação orbital a $37^{\circ} \mathrm{C}$ por $16 \mathrm{~h}$ para expansão da colônia. Em seguida, os plasmídeos das colônias foram purificados com um kit para mini-prep (Eppendorf). O sistema desse kit consiste de 2 processos acoplados: primeiramente, ocorre a lise alcalina, onde o DNA plasmidial é liberado das células e separado das proteínas, do DNA cromossomal e do RNA; em seguida, o DNA plasmidial é ligado a uma matriz numa alta concentração de sal. Sob estas condições, o DNA é rapidamente conduzido do lisado até a matriz, enquanto pequenas moléculas de RNA permanecem 
em solução. As partículas da matriz são decantadas por centrifugação e lavadas com etanol contendo baixa concentração de sal. O DNA plasmidial é eluído da matriz com o tampão de eluição, concentrado por precipitação com etanol e ressuspendido em água. Após a obtenção do DNA foi feita uma PCR com iniciadores específicos para o vetor pLIP6-GN utilizando o programa descrito no item 2.2 , os produtos obtidos foram analisados em gel de agarose 1,5\% em tampão de eletroforese TBE (Tris 90 mM, ácido bórico $90 \mathrm{mM}$, EDTA $50 \mathrm{mM}, \mathrm{pH}$ 8,0) na presença de brometo de etídeo e o tamanho das bandas foi observado.

\subsection{7 - EXPRESSÃO DA PROTEÍNA HíBRIDA: GAL-3 CONJUGADA A FOSFATASE ALCALINA}

A proteína híbrida galectina-3 conjugada a fosfatase alcalina foi obtida através de choque osmótico. Este protocolo ${ }^{153}$ permite que proteínas exportadas para o periplasma sejam extraídas. Uma colônia da bactéria BL21 foi inoculada em $4 \mathrm{~mL}$ de meio LB líquido, acrescido de ampicilina (100 $\mu \mathrm{g} / \mathrm{mL}$ ) e colocado em agitador orbital por $16 \mathrm{~h}$ a $37^{\circ} \mathrm{C}$ para expansão da colônia. Em seguida, a cultura saturada foi diluída 1:50 e expandida por aproximadamente $3 \mathrm{~h}$, até alcançar a $A_{600}=0,8$ (fase log de crescimento). Após a adição de 200 mM de IPTG a cultura ficou mais $3 \mathrm{~h}$ no agitador orbital a $37^{\circ} \mathrm{C}$ para a expressão da proteína. A cultura foi então centrifugada a $5000 \mathrm{xg}$ por $5 \mathrm{~min}$ a $4^{\circ} \mathrm{C}$ e o sobrenadante descartado. O pellet foi ressupendido em $5 \mathrm{~mL}$ de solução de sacarose $20 \%$ e incubado a temperatura ambiente por 10 min. Logo após, a solução foi centrifugada a $5000 \mathrm{xg}$ por 5 min e o sobrenadante descartado. O pellet foi então 
ressuspendido em $5 \mathrm{~mL}$ de $\mathrm{MgCl}_{2}$ 0,05 $\mathrm{mM}$ gelado e incubado em gelo por 10 min sob leve agitação. A solução foi centrifugada a 10.000 xg por $10 \mathrm{~min}$, o pellet descartado e o sobrenadante estocado a $-20^{\circ} \mathrm{C}$. A Figura 7 esquematiza a geração de uma proteína híbrida, por exemplo a galectina-3 conjugada a fosfatase alcalina. Em seguida, algumas alíquotas do sobrenadante contendo a Gal-3/FA foram purificadas, dialisadas, concentradas e tiveram a sua concentração protéica determinada.

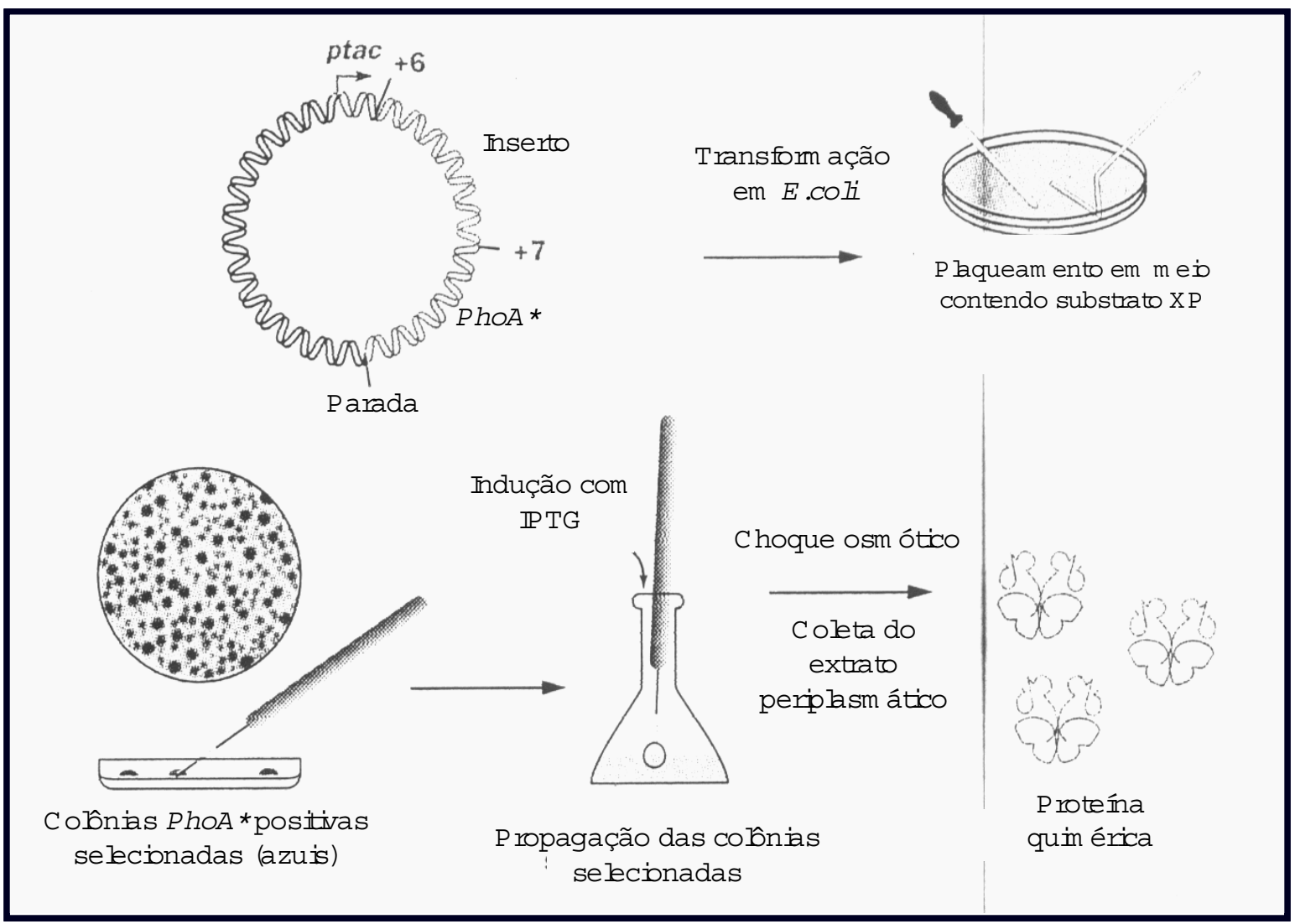

FIGURA 7. Representação esquemática da geração de uma proteína fusionada com a fosfatase alcalina

\subsection{8 - SEQUENCIAMENTO DA GAL-3/FA}

O seqüenciamentos foi feito no Centro de Biotecnologia do Instituto Butantan pelo método de terminação de cadeia por dideoxinucleotídeos ${ }^{154}$. 
Os iniciadores utilizados foram os mesmos usados na triagem dos clones. As reações de PCR foram feitas em volumes de $20 \mu \mathrm{L}$ utilizando $500 \mathrm{ng}$ do plasmídeo, 3,2 pmol de iniciador, $2 \mu \mathrm{L}$ de Big Dye 2 (Applied Biosystems) e $6 \mu \mathrm{L}$ de tris $200 \mathrm{mM}$ pH9,0 e $5 \mathrm{mM} \mathrm{MgCl}_{2}$ ). As reações de seqüenciamento foram feitas no seqüenciador $A B I 3100$ da Applied Biosystems, utilizando eletroforese capilar.

\subsection{9 - WESTERN BLOTTING}

A proteína Gal-3/FA foi separada por eletroforese em gel de poliacrilamida segundo o protocolo de LaemmLi em condições redutoras ou não e o gel foi corado com Coomassie blue ou transferido para uma membrana de PVDF como descrito acima.

Para bloquear os sítios inespecíficos, a membrana foi incubada em leite desnatado Molico (Nestlè) 5\% em PBS por $1 \mathrm{~h}$ a temperatura ambiente. Depois de lavada 3 vezes com PBS por 10 min, a membrana foi incubada por $16 \mathrm{~h} \mathrm{a} 4^{\circ} \mathrm{C}$ com o anticorpo monoclonal anti-galectina-3 M3/38 (ATCC) ou com o anticorpo anti-fosfatase alcalina (Chemicon, Temecula, CA), novamente lavada com leite Molico em PBS 3 vezes por 10 min e incubada com os anticorpos secundários anti-IgG de rato conjugado a peroxidase $(0,5$ $\mu \mathrm{g} / \mathrm{mL})(\mathrm{KPL}-$ Kirkegaard \&Perry Laboratories, Maryland, USA) ou anti-IgG de coelho conjugado a peroxidase (Sigma, St. Louis, Minessota) diluído em leite Molico/PBS por $1 \mathrm{~h}$ a temperatura ambiente, respectivamente. A membrana foi revelada com 7,5 mL de uma solução de Tris-HCL 0,05\% pH 7,8, $\mathrm{NaCl}$ 150mM, $10 \mu \mathrm{l}$ de $\mathrm{H}_{2} \mathrm{O}_{2}$ e $3.75 \mathrm{mg}$ de DAB (3,3-Diaminobenzidina 
- Sigma, St. Louis, MO). A reação foi interrompida pela imersão da membrana em água destilada após o aparecimento das bandas.

\section{3- ENSAIO DE ELISA (Enzyme Linked Immunosorbent Assay - ensaio de adsorção imunoenzimático)}

Com o objetivo de avaliar a atividade de ligação a carboidratos da galectina-3 recombinante (atividade do CRD) e das atividades de ligação a carboidratos e enzimática da Gal-3/FA foram realizados ensaios de ELISA. Para determinar a atividade da galectina-3 recombinante, placas de 96 poços (Corning, NY) foram sensibilizadas com $10 \mu \mathrm{g} / \mathrm{mL}$ de laminina-1 isolada do tumor de camundongo Engelbreth-Holm-Swarm (EHS) por $1 \mathrm{~h} \mathrm{a}$ temperatura ambiente. Controles foram feitos sensibilizando as placas com BSA 1\%. Em seguida, as placas foram lavadas com PBS/BSA 1\% 3 vezes de 10 min cada e incubadas com concentrações crescentes de galectina-3 recombinante $(0 ; 2,5 ; 5,0$ e $10,0 \mu \mathrm{g} / \mathrm{mL})$ na ausência ou presença de lactose $50 \mathrm{mM}$ por $16 \mathrm{~h}$ a $4^{\circ} \mathrm{C}$. Após a fixação com paraformaldeído 1\% (Sigma, St. Louis, MO) por $15 \mathrm{~min}$, as placas foram novamente lavadas 3 vezes com PBS/BSA 1\% e incubadas com o anticorpo monoclonal anti-galectina-3 M3/38 por $1 \mathrm{~h}$ a temperatura ambiente. Em seguida, as placas foram lavadas com PBS/BSA 1\% 3 vezes e incubadas com anticorpo anti-rato conjugado a peroxidase $(0,5 \mu \mathrm{g} / \mathrm{mL})(\mathrm{KPL}$ - Kirkegaard \&Perry Laboratories, Maryland, USA) por $1 \mathrm{~h}$ a temperatura ambiente. Depois que as placas foram lavadas com PBS/BSA $1 \% 3$ vezes as placas foram reveladas com $0,4 \mathrm{mg} / \mathrm{mL}$ de OPD (O-Phenylenediamine) (Sigma, St. Louis, MO) dissolvidos em $1 \mathrm{~mL}$ de 
tampão citrato-fosfato $0,05 \mathrm{M}$, pH 5.0 e $10 \mu \mathrm{l}$ de $\mathrm{H}_{2} \mathrm{O}_{2} 30 \%$ (Fluka). As placas foram homogeneizadas vagarosamente para evitar a formação de bolhas e após 15 min sua absorbância a 415 nm foi determinada.

E para avaliar a atividade de ligação a carboidratos e enzimática da Gal-3/FA, as placas de 96 poços (Corning, NY) foram sensibilizadas com 10 $\mu \mathrm{g} / \mathrm{mL}$ de laminina-1 isolada do tumor de camundongo Engelbreth-HolmSwarm (EHS) por $1 \mathrm{~h}$ a temperatura ambiente. Controles foram feitos sensibilizando as placas com BSA 1\%. Em seguida, as placas foram lavadas com PBS/BSA 1\% 3 vezes de 10 min cada e incubadas com concentrações crescentes de extrato periplasmático de Gal-3/FA $(0 ; 2,5 ; 5,0$ e 10,0 $\mu \mathrm{g} / \mathrm{mL})$ na ausência ou presença de lactose $50 \mathrm{mM}$ por $16 \mathrm{~h}$ a $4^{\circ} \mathrm{C}$. Após a fixação com paraformaldeído 1\% (Sigma, St. Louis, MO) por 15 min, as placas foram novamente lavadas 3 vezes com TBS e, em seguida, reveladas com 5 mg de $p$-nitrofenilfosfato dissolvido em $5 \mathrm{~mL}$ do tampão di-etanolamina 5x (BioRad Laboratoris, Hercules, CA). As placas foram homogeneizadas min sua absorbância a 492 nm foi determinada vagarosamente para evitar a formação de bolhas e após 15

\section{4- ENSAIO DE LIGAÇÃO DIRETA}

O ensaio de ligação direta foi feito para avaliar a especificidade fina da Gal-3/FA. Diversos glicanos (30 pmL/poço) (Glycan Array versão v2.3, NIGMS Consórcio para glicômica funcional) foram adicionados numa placa HBC NeutrAvidin Black com 384 poços. A placa foi então lavada com 0,05\% de Tween 20 em PBS e incubada com $15 \mu \mathrm{g} / \mathrm{mL}$ de Gal-3/FA em tampão de 
lavagem e $1 \%$ de PBS. A lectina ligada foi detecta com anticorpos antifosfatase alcalina seguida da incubação com anticorpo secundário conjugado a Alexia 488 e analisada através de um fluorímetro.

\section{5- CULTURA DE CÉLULAS}

Os fibroblastos $\mathrm{NIH}-3 \mathrm{~T} 3$ transfectados com o oncogene EJ-ras (células CCR2) e as células $\Sigma 12$ foram cultivadas em "Dulbecco's modified Eagle medium" (DMEM, GIBCO-BRL, Grand Island, NY) suplementado com 10\% de SFB (SFB, GIBCO BRL, Grand Island, NY) e as células B16F10 foram cultivadas em RPMI 1640 (GIBCO BRL, Grand Island, NY) suplementado com $10 \%$ de SFB a $37^{\circ} \mathrm{C}$ em atmosfera úmida contendo $5 \%$ de $\mathrm{CO}_{2}$. Ao atingirem cerca de $90 \%$ de confluência, as células foram lavadas com o tampão fosfato/salina (PBS) e retiradas da garrafa para repique pela adição de uma solução de tripsina $0,2 \%$. Em seguida, a ação proteolítica da tripsina foi bloqueada pela adição de meio de cultura suplementado com $10 \%$ de SFB.

\section{6- TRATAMENTO DAS CÉLULAS COM INIBIDORES DE $\mathrm{N}$ - GLICOSILAÇÃo}

Após aderidas, as células CCR2 e $\Sigma 12$ foram tratadas com $1 \mathrm{mM}$ de deoximanojirimicina (dMN, Sigma, St. Louis, MO), um inibidor de $\alpha$ manosidase I, por $24 \mathrm{~h}$ em condições de cultura. Num segundo experimento, as células B16F10 e $\Sigma 12$ foram tratadas com $1 \mu \mathrm{g} / \mathrm{mL}$ de swainsonina (SW), um inibidor de $\alpha$-manosidase $\|$ por 48 h em condições de cultura. Após 
serem lavadas com PBS, as células foram ressuspendidas em $1 \mathrm{~mL}$ de tampão de lise (Triton X-100 1\%, NaCl 150 mM, Tris 50 mM pH7,4), contendo os inibidores de proteases EDTA $5 \mathrm{mM}$, aprotinina $2 \mu \mathrm{g} / \mathrm{mL}$ (Sigma, St. Louis, MO) e PMSF 1 mM e transferidas para um tubo Eppendorf (Hamburg, Alemanha). O lisado foi submetido à agitação por 15 min a $4^{\circ} \mathrm{C}$ e o extrato solúvel foi isolado do material precipitado insolúvel após centrifugação a 13000 xg (Spin I, Incibrás) por 15 min a $4^{\circ} \mathrm{C}$. Os extratos foram então mantidos a $-20^{\circ} \mathrm{C}$ até o momento do uso, quando sua concentração protéica foi determinada.

\section{7- TRATAMENTO COM NEURAMINIDASE}

Animais C57BL/6 foram sacrificados através de deslocamento cervical. Após assepsia local, os timos foram retirados e lavados com PBS. Foram feitos extratos protéicos dos timócitos com tampão de lise como descrito acima. Em seguida, $50 \mu \mathrm{g}$ de extrato protéico de timócitos foram tratados ou não com 100 mU de neuraminidase de Arthrobacter ureafaciens (Sigma, St. Louis, MO) em tampão acetato pH 5.0 por $1 \mathrm{~h}$ a $37^{\circ} \mathrm{C}$. Controles foram feitos incubando-se os timócitos apenas com o tampão acetato. Em seguida, as amostras foram separadas em gel de poliacrilamida/SDS como descrito a seguir. 


\section{8- ENSAIO DE OVERLAY}

O ensaio de overlay é um método adequado para estudar interações proteína-carboidrato e conseqüentemente para identificar potenciais ligantes de proteínas como as galectinas.

Para identificar o padrão dos ligantes de galectina-3, os extratos protéicos das células CCR2 e $\Sigma 12$ tratadas ou não com dMN e os extratos protéicos da células B16F10 e $\Sigma 12$ tratadas ou não com SW, e os extratos dos timócitos tratados ou não com neuraminidase foram separados em eletroforese em gel de poliacrilamida segundo o protocolo de LaemmLi em condições redutoras a $4^{\circ} \mathrm{C}$ e sob uma voltagem constante de $100 \mathrm{~V}$. Em seguida, o gel foi eletroforeticamente transferidos para membrana de PVDF (Hydrophobic polyvinylidene difluoride, Amersham, Buckinghamshire, Inglaterra) por duas $\mathrm{h}$ a $150 \mathrm{~V}$ a $4^{\circ} \mathrm{C}$.

Para bloquear os sítios inespecíficos, as membranas foram incubadas em BSA/ PBS $1 \%$ por $1 \mathrm{~h}$ a temperatura ambiente. Depois de lavada 3 vezes com PBS por 10 min, as membranas foram incubadas por $16 \mathrm{~h} \mathrm{a} 4^{\circ} \mathrm{C}$ com $10 \mu \mathrm{g} / \mathrm{mL}$ das lectinas GNA (Galanthus nivalis agglutinin) conjugada a digoxigenina, PNA (Peanut agglutinin) conjugada a digoxigenina ou com LPHA (Phaseolus vulgaris) conjugada a biotina (Roche Diagnostics, Mannheim, Germany). Após a lavagem com PBS 3 vezes, as membranas foram incubadas com $7,5 \mu \mathrm{g} / \mathrm{mL}$ dos anticorpos anti-digoxigenina conjugado a fosfatase alcalina e anti-biotina conjugada a fosfatase alcalina. Em seguida, as membranas foram lavadas com TBS (150 mM NaCl, $50 \mathrm{mM}$ Tris- 
$\mathrm{HCl}, \mathrm{pH} 7.5) 3$ vezes e com o tampão 1 (TBS with $1 \mathrm{mM} \mathrm{MgCl}$, $1 \mathrm{mM} \mathrm{MnCl} 2$ e $1 \mathrm{mM} \mathrm{CaCl}_{2}, \mathrm{pH}$ 7.5) uma vez. As membranas foram então reveladas com o substrato para fosfatase alcalina NBT/BCIP dissolvido no tampão 1. As membranas também foram incubadas com $30 \mu \mathrm{g} / \mathrm{mL}$ de Gal-3/FA por $16 \mathrm{~h}$ a $4^{\circ} \mathrm{C}$, lavadas com TBS e reveladas como descrito acima. As reação foram interrompidas pela imersão das membranas em água destilada após o aparecimento das bandas.

\section{9- IMUNOISTOQUÍMICA: USO DA GALECTINA-3 CONJUGADA A FOSFATASE ALCALINA EM TECIDOS}

A reação de imunoistoquímica foi realizada no Instituto Ludwig em colaboração com Suely Nonogaki. Foram utilizadas lâminas de tissue-array contendo os seguintes tecidos: carcinoma de mama, retinoblastoma, melanoma, carcinoma de próstata, carcinóide e tecidos normais de sistema nervoso central, de mama, de pele, de pâncreas, de próstata e de retina. Também foram analisados os timos e sarcomas induzidos com metilcolantreno de animais C57BL/6. Após processamento histológico padrão, seguida da recuperação antigênica com tampão citrato pH 6.0 no microondas e bloqueio da fosfatase alcalina endógena, as lâminas foram incubadas com $16 \mu \mathrm{g} / \mathrm{mL}$ de Gal-3/FA na ausência e presença de $100 \mathrm{mM}$ de lactose (Sigma, St. Louis, MO) a $4^{\circ} \mathrm{C}$ por $22 \mathrm{~h}$. Também foi feito um controle negativo, incubando-se a lâmina com BSA 1\%. Após a incubação as lâminas foram lavadas 3 vezes com PBS/BSA 1\% e reveladas com 3 mg do substrato para fosfatase alcalina Fast Red (Dako, Carpinteria, CA) dissolvido 
em $3 \mathrm{~mL}$ de tampão Naftol fosfato em Tris-HCl. Em seguida, foi feita a coloração com hematoxilina. Após a lavagem com água, as lâminas foram secas e montadas com o meio de montagem Aquatex (Merck, Darmstardt, Germany). As lâminas contendo tecidos murinos também foram incubados com o anticorpo anti-galectina-3 (M3/38) diluído 16 vezes e com a lectina vegetal L-PHA conjugado a biotina a $4^{\circ} \mathrm{C}$ por $22 \mathrm{~h}$. Em seguida, foram lavados com PBS/BSA 1\% e incubados com o anticorpo anti-rato conjugado a peroxidase (Vector) e com estreptoavidina conjugada a peroxidase (Dako, Carpinteria, CA) todos diluídos em PBS por $1 \mathrm{~h}$ a $37^{\circ} \mathrm{C}$. Em seguida as lâminas foram lavadas com PBS/BSA 1\% e reveladas com 60 mg de DAB (3,3 - Diaminobenzidina - Sigma, Steinheim, Germany), $1 \mathrm{~mL}$ de $\mathrm{H}_{2} \mathrm{O}_{2}$ e 1 $\mathrm{mL}$ de DMSO. A contra coloração foi feita com hematoxilina. Depois que as lâminas foram lavadas abundantemente com água para retirada do excesso de corante, foi realizado o processo inverso para retirada de toda a água do tecido e a montagem das lâminas foi feita com o meio de montagem Entelan (Merck, Darmstardt, Germany).

\subsection{0- ENSAIO DE MIGRAÇÃO - WOUND HEALING}

$3 \times 10^{4}$ células $\Sigma 12$ foram plaqueadas em lamínulas circulares em meio DMEM com 10\% de SFB e mantidas em condições de cultura. Após 24 $h$, as células foram lavadas e foi feito um risco nas lamínulas que retirou as camadas de células. Este risco levou a uma descontinuidade da superfície coberta por células. As células à margem desta descontinuidade tendem então a migrar para os espaços vazios. Assim, depois de feito o risco, as 
células foram incubadas com $10 \mu \mathrm{g} / \mathrm{mL}$ de laminina-1 (Sigma, St. Louis) na ausência ou na presença de $20 \mu \mathrm{g} / \mathrm{mL}$ de galectina-3 e também na presença

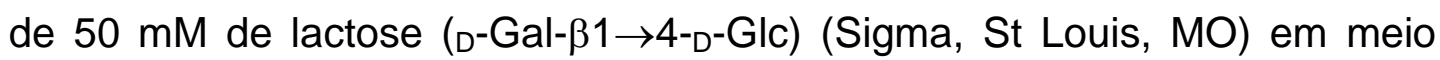
DMEM sem soro a $37^{\circ} \mathrm{C}$. Ensaios também foram feitos na presença de $1 \mu \mathrm{M}$ de wortmanina (Sigma, St. Louis), um inibidor de PI(3) quinase. Controles foram feitos incubando-se as células somente com meio DMEM ou com DMSO (Sigma, St. Louis). Após 24 h, as células foram lavadas com PBS e fixadas com 4\% de paraformaldeído em tampão PEM (tampão fosfato 0,1 M pH 7,4, contendo 10 mM PIPES, 5 mM EGTA e 2 mM $\mathrm{MgCl}_{2}$ )/0,1\% Triton-X100 por 15 min a temperatura ambiente. Em seguida, as células foram bloqueadas com BSA 1\% em PBS e seus núcleos corados com 0,1 $\mu \mathrm{g} / \mathrm{mL}$ de DAPI (4'6-Diamidino-2-fenilindolil di-lactato) (Sigma, St. Louis) por 5 min. Após 3 lavagens de 10 min cada com BSA 1\% em PBS, as lamínulas foram montadas em lâminas com uma solução de glicerol/carbonato (29 mL de Carbonato de sódio 0,5 M, $71 \mathrm{~mL}$ de Bicarbonato de sódio 0,5 M e 90\% de glicerol puro) e examinadas ao microscópio de fluorescência Nikon Eclipse E600. Imagens de 10 campos de cada lamínula foram digitalizadas com a câmera Nikon Digital DXM 1200F. Para quantificar o número de células migratórias, imagens dos riscos com tamanho padronizado foram selecionadas e o número de células contadas com o programa Eclipse net. As análises foram feitas usando o método ANOVA, seguido do teste $t$ de Bonferroni para múltiplas comparações, usando-se o software Prism 3.0. 


\subsection{1 - ISOLAMENTO DOS COMPLEXOS FOCAIS}

$5 \times 10^{6}$ células $\Sigma 12$ foram plaqueadas em placas de $100 \mathrm{~mm}$ em meio DMEM com $10 \%$ de SFB e mantidas em condições de cultura. Depois de aderidas, as células foram lavadas com PBS e incubadas na presença ou ausência de $20 \mu \mathrm{g} / \mathrm{mL}$ de galectina-3 e na ausência ou presença de $50 \mathrm{mM}$ de lactose em meio DMEM sem soro. Após 15 min e 24 h os complexos focais dessas células foram isolados segundo o protocolo de Avnur e Geiger 155 citado por Niederreiter e Gimona ${ }^{156}$. As células foram lavadas 2 vezes com o tampão C (glicose 5,5 mM, KCl 5,4 mM, NaCl 137 mM, $\mathrm{KH}_{2} \mathrm{PO}_{4}$ 0,4 $\mathrm{mM}, \mathrm{Na}_{2} \mathrm{HPO}_{4} \cdot \mathrm{H}_{2} \mathrm{O}$ 0,4 mM, $\mathrm{NaHCO}_{3} 4 \mathrm{mM}, \mathrm{PIPES} 3,2 \mathrm{mM}, \mathrm{MgCl}_{2} \cdot 6 \mathrm{H}_{2} \mathrm{O}$ 1,9 $\left.\mathrm{mM}, \mathrm{CaCl}_{2} \cdot 2 \mathrm{H}_{2} \mathrm{O} 0,5 \mathrm{mM}\right) \mathrm{pH} 6.1$ e incubadas com $0,2 \%$ de saponina no tampão C por 5 min. Em seguida, os corpos celulares foram removidos com a adição constante de tampão $C$ com a ajuda de uma seringa. $O$ fluxo de tampão $C$ foi mantido constante para retirada de todas as células. As placas foram visualizadas ao microscópio óptico para verificar se todas as células haviam sido retiradas. Após a remoção dos corpos celulares, foi adicionado o tampão de lise (uréia 8 M, Tween 201 mM, DTT 100 mM) por 5 min para extração dos complexos focais. Em seguida, o extrato foi coletado em Eppendorf (Hamburg, Alemanha) e estocado a $-20^{\circ} \mathrm{C}$ até o momento do uso.

Os extratos dos complexos focais foram separados em gel de poliacrilamida/SDS em condições redutoras e transferidos para membrana de PVDF. Para bloquear os sítios inespecíficos a membrana foi incubada em leite desnatado Molico (Nestlè) 5\% em PBS com 0,1 \% Tween 20 Calbiochem) por $1 \mathrm{~h}$ a temperatura ambiente. Depois de lavada 3 vezes por 
10 min com PBS 0,1\%Tween 20, a membrana foi incubada por $16 \mathrm{~h}$ a $4^{\circ} \mathrm{C}$ com o anticorpo monoclonal anti-galectina-3 M3/38 (ATCC), com $2 \mu \mathrm{g}$ do anticorpo policlonal de cabra anti- $\beta 1$ integrina (Santa Cruz Biotechnology, INC), com $2 \mu \mathrm{g}$ do anticorpo policlonal de coelho anti-FAK (Santa Cruz Biotechnology, INC), com $2 \mu \mathrm{g}$ do anticorpo policlonal de coelho anti-SHP-2 (Santa Cruz Biotechnology, INC) e com o anticorpo monoclonal anti-actina (Affinity BioReagents, Golden, CO). Após ser lavada novamente 3 vezes com PBS 0,1\%Tween 20, a membrana foi incubada por $1 \mathrm{~h}$ com os anticorpos anti-rato conjugado a peroxidase, anti-cabra conjugado a peroxidase e anti-coelho conjugado a peroxidase (Sigma, St. Louis, Missouri), respectivamente. Em seguida, a membrana foi lavada com PBS 0,1\%Tween 20 e revelada com o kit para quimioluminescência ECL (Amersham Biosciences, Buckinghamshire, UK) segundo as recomendações do fabricante ou com 7,5 mL de uma solução de Tris-HCL 0,05\% pH 7,8, $\mathrm{NaCl}$ 150mM, $10 \mu \mathrm{l}$ de $\mathrm{H}_{2} \mathrm{O}_{2}$ e $3.75 \mathrm{mg}$ de DAB (3,3-Diaminobenzidina Sigma, St. Louis, MO). A reação foi interrompida pela imersão da membrana em água destilada após o aparecimento das bandas.

\subsection{2- ANÁLISE DA ENDOCITOSE DE $\beta_{1}$ INTEGRINA POR CITOMETRIA DE FLUXO}

Para estudar a internalização de $\beta_{1}$ integrina, células que não expressam galectina-3 (linhagens $\Sigma 12$ ) foram incubadas com galectina-3 recombinante nas concentrações de 20 e $40 \mu \mathrm{g} / \mathrm{mL}$ na ausência e na presença de $100 \mathrm{mM}$ de lactose (Sigma, St. Louis, MO) por $1 \mathrm{~h}$ a $37^{\circ} \mathrm{C}$. Em 
seguida, as células foram lavadas com PBS/BSA 1\% por 2 vezes e incubadas com 2,5 $\mu \mathrm{g}$ do anticorpo anti-CD 29 conjugado a isotiocianato de fluoresceína (FITC) (Pharmigen, San Diego, CA) a $4^{\circ} \mathrm{C}$ por $1 \mathrm{~h}$. Controles negativos foram feitos com $1 \mu \mathrm{g}$ do anticorpo anti-IgG de camundongo conjugado a FITC (KPL - Kirkegaard \&Perry Laboratories, Maryland, USA). Após a lavagem das células com PBS/BSA 1\% as células foram analisadas em citômetro de fluxo (FacScalibur, Beckton \& Dickson, San Jose, CA, USA).

\subsection{3- IMUNOPRECIPITAÇÃO}

Extratos de células CCR2 foram pré-clareados com $10 \mu \mathrm{g} / \mathrm{mL}$ do anticorpo de coelho anti-rato (Immunotech, Marseille, France) por $1 \mathrm{~h}$ a $4^{\circ} \mathrm{C}$, seguido da incubação com a Proteína A acoplada a beads de agarose (Gibco BRL, Gaitherburg, MD)em tampão de lise (1\% Triton X-100, 150 mM $\mathrm{NaCl}, 50 \mathrm{mM}$ Tris $\mathrm{pH} 7.4,5 \mathrm{mM}$ EDTA) por 90 min a $4^{\circ} \mathrm{C}$. Em seguida, a suspensão foi centrifugada a $10.000 x g$ por 15 seg a $4^{\circ} \mathrm{C}$ e o sobrenadante coletado e incubado por $16 \mathrm{~h}$ a $4^{\circ} \mathrm{C}$ com $2 \mu \mathrm{g}$ do anticorpo policlonal de cabra anti- $\beta 1$ integrina. Em seguida, a suspensão foi incubada com Proteína A agarose por $2 \mathrm{~h}$ a $4^{\circ} \mathrm{C}$ e centrifugada a $10.000 x g$ por 15 seg a $4^{\circ} \mathrm{C}$. Os beads foram recolhidos e lavados 3 vezes com o tampão A (50 mM Tris, 500 mM, pH8.0) e 2 vezes com o tampão B (50 mM Tris, 150 mM Na Cl, pH6.8). Aos beads foram adicionados tampão de amostra redutor , os quais foram fervidos por $5 \mathrm{~min}$, separados eletroforeticamente em gel de poliacrilamidaSDS $10 \%$, transferidos para membrana de PVDF e incubados com os 
anticorpos anti- $\beta 1$ e com a galectina-3 conjugada a fosfatase alcalina (Gal3/FA).

\subsection{4- INTERNALIZAÇÃO DE GALECTINA-3}

$4 \times 10^{4}$ células $\Sigma 12$ foram plaqueadas em lamínulas circulares em meio DMEM com 10\% de SFB. Após 24 h, essas células foram lavadas com PBS e submetidas ao ensaio do risco como descrito anteriormente. Essas células foram incubadas na ausência ou presença de $20 \mu \mathrm{g} / \mathrm{mL}$ de galectina3 e na ausência ou presença de $50 \mathrm{mM}$ de lactose por $1 \mathrm{~h}$ a $37^{\circ} \mathrm{C}$. Em seguida, as células foram lavadas com PBS 2 vezes, fixadas, permeabilizadas e bloqueadas como descrito anteriormente e incubadas com o anticorpo anti-galectina-3 (M3/38) por $1 \mathrm{~h}$ a temperatura ambiente. Após 3 lavagens com PBS/BSA 1\%, as células foram incubadas com 0 anticorpo anti-rato conjugado a FITC por $1 \mathrm{~h}$ a temperatura ambiente. As células foram então lavadas novamente PBS/BSA 1\% e incubadas com DAPI por $5 \mathrm{~min}$. Controles negativos foram feitos incubando-se as células somente com o anticorpo anti-rato conjugado a FITC. Após 3 lavagens com PBS/BSA 1\% as lamínulas foram montadas em lamínulas com a solução de glicerol carbonato e visualizadas ao microscópio de fluorescência Nikon. Imagens randômicas de 10 campos de cada lamínula foram digitalizadas com a câmera da Nikon.

\subsection{5- IMUNOFLUORESCÊNCIA}

Neste ensaio, avaliamos a distribuição das fibras de actina, de FAK fosforilado, de PAK 1/2 fosforilado, da tirosino-fosfatase SHP-2 e o padrão 
de tirosinas fosforiladas na presença de galectina-3 exógena. Este ensaio foi realizado no Departamento de Biologia Celular e do Desenvolvimento do Instituto de Ciências Biomédicas da Universidade de São Paulo, em colaboração com a Profa. Dra. Marinilce F. dos Santos.

$2 \times 10^{4}$ células foram plaqueadas em lamínulas circulares em meio DMEM com $10 \%$ de SFB. Após $48 \mathrm{~h}$, as células foram lavadas e foi feito um risco nas lamínulas como descrito anteriormente. Assim, depois de feito o risco, as células foram incubadas com $10 \mu \mathrm{g} / \mathrm{mL}$ de laminina-1 na ausência ou na presença de $20 \mu \mathrm{g} / \mathrm{mL}$ de galectina-3 e na ausência ou presença de $50 \mathrm{mM}$ de lactose por 15 e $60 \mathrm{~min}$ a $37^{\circ} \mathrm{C}$. Para avaliar o padrão de tirosinas fosforiladas as células foram incubadas com $100 \mu \mathrm{M}$ de ortovanadato $\left(\mathrm{Na}_{3} \mathrm{VO}_{4}\right.$, Sigma, St. Louis). Em seguida, as células foram lavadas com tampão fosfato $0,1 \mathrm{M}\left(\mathrm{NaH}_{2} \mathrm{PO}_{4}\right.$ 0,022 $\mathrm{M}$ e $\mathrm{Na}_{2} \mathrm{HPO}_{4}$ 0,077 M) pH 7.4 por 2 vezes e fixadas com $4 \%$ de paraformaldeído em tampão PEM (tampão fosfato $0,1 \mathrm{M} \mathrm{pH} 7,4$, contendo $10 \mathrm{mM}$ PIPES, $5 \mathrm{mM}$ EGTA e $2 \mathrm{mM}$ $\left.\mathrm{MgCl}_{2}\right) / 0,1 \%$ Triton-X-100 por $15 \mathrm{~min}$ a temperatura ambiente. Após a lavagem com tampão fosfato, as células foram pós-fixadas com etanol 95\% a $-20^{\circ} \mathrm{C}$ por $5 \mathrm{~min}$, lavadas novamente com tampão fosfato e bloqueadas com PBS/BSA 1\% durante $1 \mathrm{~h}$ à temperatura ambiente. As lamínulas foram então incubadas com 2,5 $\mu \mathrm{g}$ do anticorpo monoclonal de camundongo antiFAK fosforilado (Chemicon, Temecula, CA), com 5,9 $\mu \mathrm{g} / \mathrm{mL}$ do anticorpo monoclonal anti-fosfotirosina (Sigma, St Louis, Missouri), com $0,2 \mu \mathrm{g}$ do anticorpo policlonal anti-SHP-2 (Santa Cruz Biotechnology, INC) e com o anticorpo policlonal anti-PAK $1 / 2$ fosforilado (Cell Signaling) diluído em 
tampão fosfato/Triton-X-100 0,1\% por $16 \mathrm{~h}$ a temperatura ambiente em câmara úmida. Depois que as lamínulas foram lavadas 3 vezes com tampão fosfato, foram incubadas com os anticorpos secundários anti-camundongo conjugado a Alexia 488 (Molecular Probes), anti-camundongo e anti-coelho conjugados a FITC (Jackson) no escuro a temperatura ambiente, respectivamente. Depois de 3 lavagens com tampão fosfato, estas células foram marcadas com faloidina conjugada a rodamina (Molecular Probes), reagente que se liga aos filamentos de actina, por $1 \mathrm{~h}$ a temperatura ambiente. Após 3 lavagens com tampão fosfato, as lamínulas foram montadas com solução de glicerol/carbonato e examinadas ao microscópio confocal Nikon ECM 2000. Controles negativos foram feitos incubando-se as células apenas com o anticorpo secundário. 
RESULTADOS 


\section{5- RESULTADOS}

\section{1 - EXPRESSÃO DA GALECTINA-3 HUMANA RECOMBINANTE}

O objetivo do meu projeto de doutorado foi avaliar o mecanismo de ação da galectina-3 no aumento da capacidade migratória de células de origem mesenquimal. Sendo assim, a geração da galectina-3 recombinante foi uma ferramenta muito útil na realização deste trabalho. A galectina-3 recombinante foi utilizada em ensaios que visavam a análise da distribuição de proteínas do citoesqueleto e da dinâmica de formação dos complexos focais.

A galectina-3 humana recombinante foi produzida a partir do vetor pKK233-2 transformado na bactéria JM107. Após a expressão da proteína, o lisado bacteriano foi centrifugado e o sobrenadante recolhido teve sua concentração protéica determinada para posterior avaliação de rendimento. Em seguida, o sobrenadante foi passado por uma coluna de afinidade com beads de lactosyl-Sepharose ${ }^{\circledR}$ para purificar a galectina-3. Para eluir a galectina-3 ligada aos beads foi usado $250 \mathrm{mM}$ de lactose. Após a purificação, a galectina-3 foi dialisada contra PBS para retirar o excesso de lactose e concentrada através de ultracentrifugação. A concentração da galectina-3 humana recombinante foi determinada e verificou-se que conseguimos obter 4 mg de galectina-3 a partir de 208 mg de proteínas totais. Para confirmar a expressão da galectina-3 foram realizados ensaios de western blotting. Extratos de células CCR2 (controle positivo) e amostras 
de galectina-3 humana recombinante foram separados por eletroforese em gel de poliacrilamida/SDS em condições redutoras e transferidos para a membrana de PVDF. Em seguida a membrana foi bloqueada e incubada com o anticorpo anti-galectina-3 M3/38. Após a lavagem, a membrana foi incubada com o anticorpo anti-IgG de rato conjugado a peroxidase e revelada. Foi observada uma banda de massa molecular aparente de aproximadamente $30 \mathrm{kDa}$ que corresponde a galectina-3 humana. Nas células CCR2 foi observada uma banda um pouco maior, que corresponde a galectina-3 de camundongo (Figura 8).

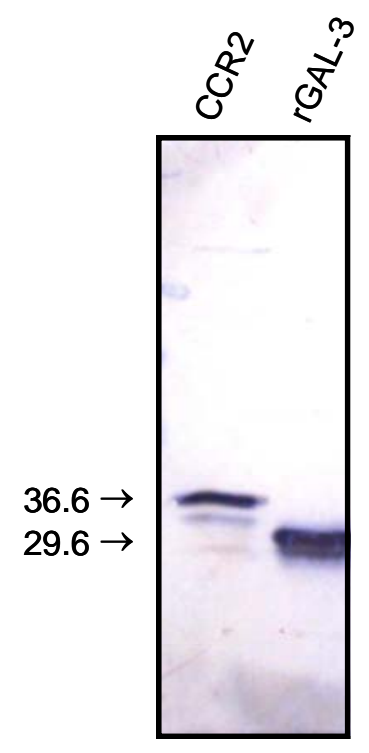

FIGURA 8. Expressão da galectina-3 humana recombinante. A galectina-3 humana recombinante produzida foi purificada em uma coluna de afinidade com beads de lactosyl-Sepharose ${ }^{\circledR}$, dialisada e concentrada. Extrato das células CCR2 (controle positivo) e a galectina-3 recombinante foram separadas em gel de poliacrilamida/SDS em condições redutoras, transferidas para membrana de PVDF e analisadas com o anticorpo monoclonal anti-galectina-3 (M3/38). A banda de massa molecular aparente de aproximadamente $30 \mathrm{kDa}$ corresponde a galectina-3 humana. As células CCR2 apresentam uma banda um pouco maior, que corresponde a galectina-3 de camundongo. 


\section{2- A LIGAÇÃO DA GALECTINA-3 HUMANA RECOMBINANTE À LAMININA-1 É INIBIDA NA PRESENÇA DE LACTOSE}

Glicoproteínas que contém polilactosaminas, entre elas, a laminina-1 de EHS, foram identificadas como ligantes de galectina- ${ }^{157}, 158$. Portanto, para avaliar a atividade de ligação da galectina-3 humana recombinante foram realizados ensaios de ELISA, onde laminina-1 foi usada como substrato. $O$ ensaio foi realizado como descrito em materiais e métodos. $\mathrm{O}$ resultado mostrou que a galectina-3 se ligou a laminina-1, e não ao BSA, de maneira dose-dependente, indicando a especificidade de ligação da galectina-3 recombinante (Figura 9). A ligação de galectina-3 à laminina-1 foi inibida por $50 \mathrm{mM}$ de lactose. Esses dados mostram que o domínio de reconhecimento de carboidratos (CRD) da galectina-3 humana recombinante é funcional. 


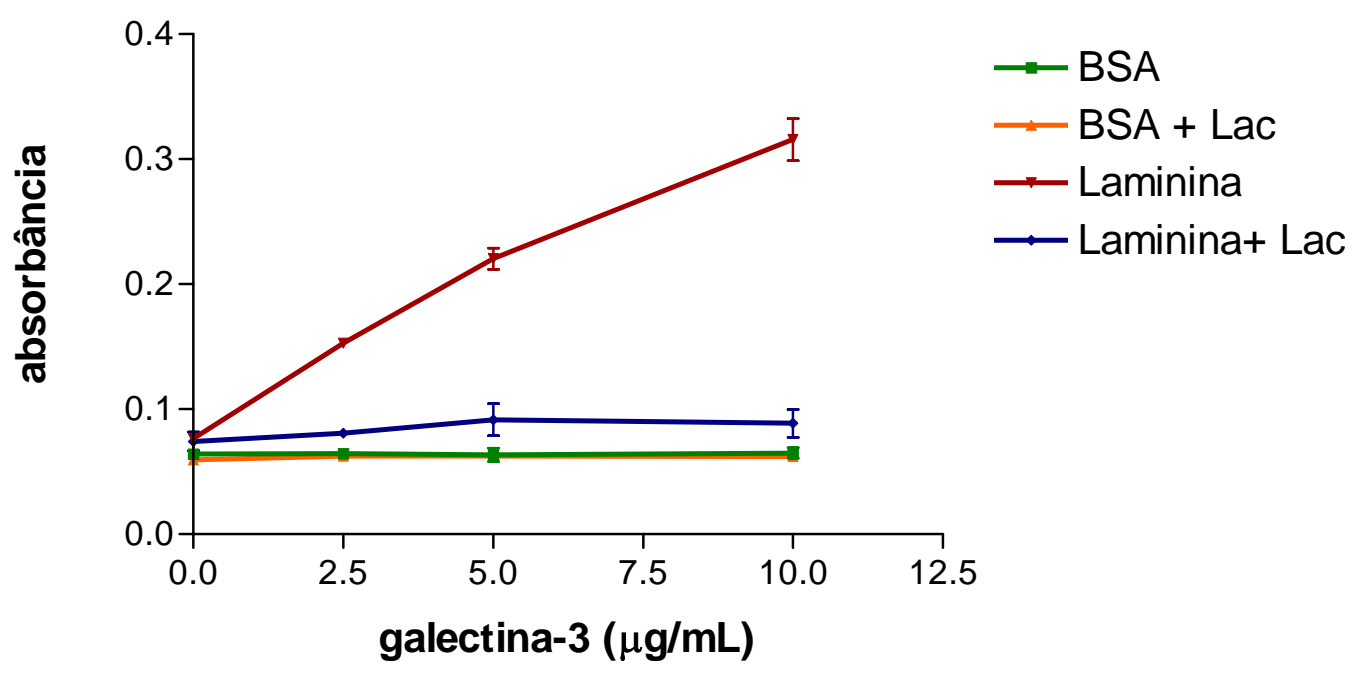

FIGURA 9 - A atividade de galectina-3 humana recombinante é inibida na presença lactose. A atividade da galectina-3 recombinante foi avaliada em ensaio de ELISA. A placa foi sensibilizada com $10 \mu \mathrm{g} / \mathrm{ml}$ de laminina-1, bloqueada com PBS/BSA 1\% e em seguida incubada com concentrações crescentes de galectina3 recombinante na presença ou ausência de $50 \mathrm{mM}$ de lactose. A placa foi então incubada com anticorpo antigalectina-3 e em seguida com o anticorpo anti-rato conjugado a peroxidase. Após a revelação, a absorbância a $492 \mathrm{~nm}$ foi determinada. Controles negativos foram feitos com BSA 1\%. A galectina-3 se ligou a laminina-1 de maneira dose-dependente. A interação entre a galectina-3 e a laminina-1 foi inibida na presença de lactose.

\section{3 - CONSTRUÇÃo E GERAÇÃO DA GALECTINA-3 CONJUGADA A FOSFATASE ALCALINA}

A aquisição do fenótipo metastático é acompanhado de alterações de glicosilação de resíduos de asparagina em glicoproteínas (aparecimento de complexos tri- e tetra-antenares apresentando um resíduo de $\mathrm{N}$-acetilglucosamina ligada em configuração $\beta 1-6$ a manose), reconhecidas pela lectina vegetal L-PHA, que apresenta, segundo a literatura, especificidade semelhante a galectina-3 ${ }^{159}, 15,{ }^{17}, 114$. Com o objetivo de criar uma ferramenta útil no diagnóstico e/ou prognóstico de tumores, foi construída uma molécula híbrida, a galectina-3 conjugada a fosfatase alcalina (Gal-3FA). Além disso, a Gal-3/FA também foi utilizada como sonda em ensaios de overlay. A 
construção e geração da Gal-3/FA foram feitas em colaboração com a Dra. Ana Maria Moura da Silva e com o Dr. Diego Butera do Departamento de Imunopatologia do Instituto Butantan

Foi utilizado o vetor de fusão pLIP6-GN que permite a expressão periplasmática de proteínas exógenas em fusão com uma variante de fosfatase alcalina de E. coli. O cDNA da galectina-3 foi clonado entre os resíduos +6 e +7 do gene da fosfatase alcalina através da técinica de PCR. Primeiramente, os sítios de restrição para enzimas Sfil e Notl foram adicionados ao gene da galectina-3. O gene da galectina-3 possui 753 pares de bases. Somando-se os nucleotídeos das enzimas de restrição, o produto obtido foi de 774 pares de base (Figura 10A). Após a digestão com as enzimas de restrição do vetor e da galectina-3 foi feita a reação de ligação e a transformação das bactérias. As bactérias transformadas foram plaqueadas em meio sólido LB Agar fosfato contendo ampicilina, IPTG e substrato para fosfato alcalina. As colônias positivas obtidas apresentavam a coloração azul, resultado da modificação do substrato. Em seguida, foi feita a análise das colônias positivas através da técnica de PCR. A PCR foi realizada com iniciadores que anelam do nucleotídeo -87 a -69 (iniciador senso) do vetor e com os nucleotídeos 108 a 127 (iniciador anti-senso) do gene da fosfatase alcalina (Figura 10C). Como o cDNA da galectina-3 possui $753 \mathrm{pb}$, o produto obtido foi de $948 \mathrm{pb}$. O produto de 195 pb corresponde ao gene da fosfatase alcalina que se encontra fora da fase de leitura no vetor pLIp6-GN (Figura 10B). 

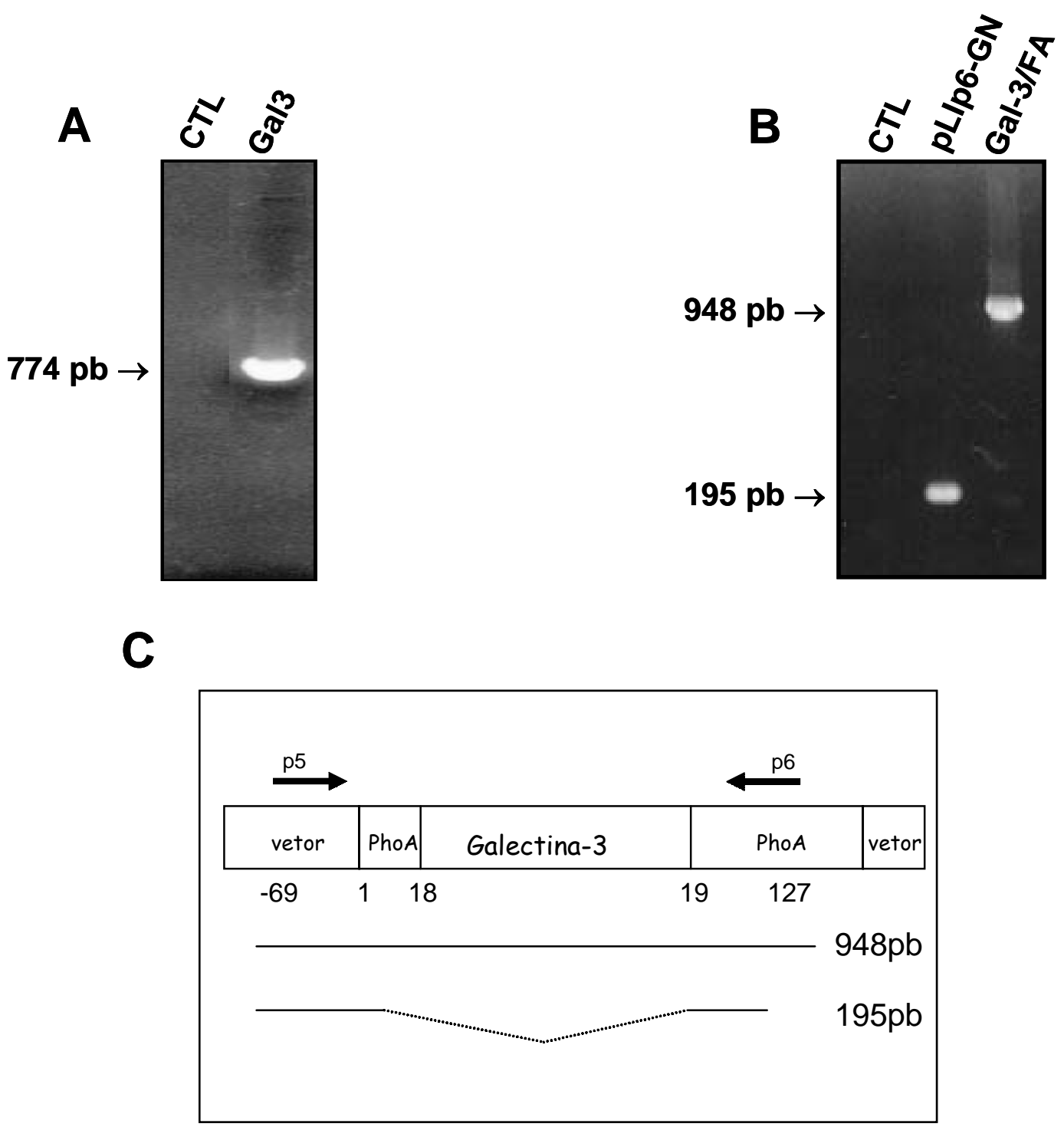

FIGURA 10 - Construção e geração da galectina-3 conjugada a fosfatase alcalina . A - Produto da reação de PCR realizado para inserir os sítios de restrição das enzimas Sfil e Notl no gene da galectina-3 humana. O tamanho do produto corresponde ao gene de galectina-3 (753 bp), incluindo os sítios de restrição. B- O gene da galectina-3 foi clonado no vetor pLIP6-GN entre os sítios Sfil e Notl localizados entre os códons +6 e +7 do gene da fosfatase alcalina. Após a digestão do produto de PCR e do vetor pLIP6-GN com as enzimas de restrição Sfil e Notl, foi realizada a reação de ligação e a triagem dos clones. O produto de 195 pb corresponde ao gene PhoA que se encontra fora da fase de leitura no vetor pLIP6-GN. O produto de 948 pb corresponde ao gene da galectina-3 e parte da proteína PhoA. C- Indicação dos iniciadores utilizados na triagem das colônias positivas.

\section{4 - SEQUENCIAMENTO DA GALECTINA-3 CONJUGADA A FOSFATASE ALCALINA}

O cDNA da galectina-3 conjugada a fosfatase alcalina foi seqüenciado para confirmar se a construção da proteína quimérica, 
galectina-3 mais fosfatase alcalina, tinha sido eficiente. A seqüência em letras maiúsculas corresponde a galectina-3 e a seqüência em letras minúsculas corresponde a fosfatase alcalina. A seqüência obtida foi comparada com as seqüências do GeneBank gi12654570 (Figura 11). 
5'...cggacaccagaaatgccggcccagccggccGCAGACAATTTTTCGCTCCATGATGCGTTATCTGGGTC TGGAAACCCAAACCCTCAAGGATGGCCTGGCGCATGGGGGAACCAGCCTGCTGGGGCAGG GGGCTACCCAGGGGCTTCCTATCCTGGGGCCTACCCCGGGCAGGCACCCCCAGGGGCTTA TCCTGGACAGGCACCTCCAGGCGCCTACCCTGGAGCACCTGGAGCTTATCCCGGAGCACCT GCACCTGGAGTCTACCCAGGGCCACCCAGCGGCCCTGGGGCCTACCCATCTTCTGGACAG CCAAGTGCCACCGGAGCCTACCCTGCCACTGGCCCCTATGGCGCCCCTGCTGGGCCACTG ATTGTGCCTTATAACCTGCCTTTGCCTGGGGGAGTGGTGCCTCGCATGCTGATAACAATTCT GGGCACGGTGAAGCCCAATGCAAACAGAATTGCTTTAGATTTCCAAAGAGGGAATGATGTTG CCTTCCACTTTAACCCACGCTTCAATGAGAACAACAGGAGAGTCATTGTTTGCAATACAAAGC TGGATAATAACTGGGGAAGGGAAGAAAGACAGTCGGTTTTCCCATTTGAAAGTGGGAAACCA TTCAAAATACAAGTACTGGTTGAACCTGACCACTTCAAGGTTGCAGTGAATGATGCTCACTTG TTGCAGTACAATCATCGGGTTAAAAAACTCAATGAAATCAGCAAACTGGGAATTTCTGGTGAC ATAGACCTCACCAGTGCTTCATATACCATGATgcggccgcagttctggaaaaccgggctgctcagggcgatattac tgcacccggcggtgctcgccgtttaacgggtgatcagactgccgctctgcgtgattctcttagcgataaacctgcaaaaaatattattttgctg attggcgatgggatgggggactcggaaattactgccgcacgtaattatgccgaaggtgcgggcggctttttaaaggtatagatgccttacc gcttaccgggcaatacactcactatgcgctgaataaaaaaaccggcaaaccggactacgtcaccgactcggctgcatcagcaaccgcc tggtcaaccggtgtcaaaacctataacggcgcgctgggcgtcgatattcacgaaaaagatcacccaacgattctggaaatggcaaaag ccgcaggtctggcgaccggtaacgtttctaccgcagagttgcaggatgccacgcccgctgcgctggtggcacatgtgacctcgcgcaaa tgctacggtccgagcgcgaccagtgaaaaatgtccgggtaacgctctggaaaaaggcggaaaaggatcgattaccgaacagctgctta acgctcgtgccgacgttacgcttggcggcggcgcaaaaaccttgctgaaacggcaaccgctggtgaatggcagggaaaaacgctgc gtgaacaggcacaggcgcgtggttatcagttggtgagcgatgctgcctcactgaattcggtgacggaagcgaatcagcaaaaacccctg cttggcctgtttgctgacggcaatatgccagtgcgctggctaggaccgaaagcaacgtaccatggcaatatcgataagcccgcagtcacc tgtacgccaaatccgcaacgtaatgacagtgtaccaaccctggcgcagatgaccgacaaagccattgaattgttgagtaaaaatgagaa aggcttttcctgcaagttgaaggtgcgtcaatcgataaacaggatcatgctgcgaatccttgtgggcaaattggcgagacggtcgatctcg atgaagccgtacaacgggcgctggaattcgctaaaaaggagggtaacacgctggtcatagtcaccgctgatcacgcccacgccagcc agattgttgcgccggataccaaagctccgggcctcacccaggcgctaaataccaaagatggcgcagtgatggtgatgagttacgggaa ctccgaagaggattcacaagaacataccggcagtcagttgcgtattgcggcgtatggcccgcatgccgccaatgttgttggactgaccga ccagaccgatctcttctacaccatgaaagccgctctggggctgaaataaaaccgcgcccggcagtgaattttcgctgccgggtggttttttg ctgttagcaaccagacttaatggcagatcacgggcgcatacgctcatggttaaaacatgaagagggatggtgctatgaaaataacattac tggttaccttgcttttcggtctggttttttaaccaccgtcggcgctgccgagagaactttaaccccacaacaacagcgtatgacctcctgtaat cagcaggcgacggcgcaggcgttgaaaggggatgctcgtaagacctacatgagtgattgcctgaagaacagcaagtctgcgcctggc gaaaaaagtttgacgccacagcagcaaaagatgcgcgaatgcaataatcaagcaacacaacaatctctgaaaggtgatgatcgtaat aagtttatgagtgcctgcctcaagaaagccgcctgatacctgatagtgctaacgggtgagctacgaaaatggctcacccgaaatatcata cttctgcctttagctccgtctctataatttgggaaaattgtttctgaatgttcccaaaaataa.... $3^{\prime}$......

FIGURA 11. Sequenciamento da galectina-3 conjugada a fosfatase alcalina. Esquema representando a sequência da galectina-3 conjugada a fosfatase alcalina, onde as seqüências em letra minúscula representam o gene fosfatase alcalina, e as em letra maiúscula representam o gene da galectina-3. Em vermelho estão marcados os sítios de restrição para as enzimas Sfil e Notl, respectivamente, onde foi inserido o gene da galectina-3.

\section{5 - EXPRESSÃO DA GALECTINA-3 CONJUGADA A FOSFATASE}

\section{ALCALINA}

A fosfatase alcalina possui um peptídeo sinal que a endereça para o

periplasma da bactéria, permitindo que a Gal-3/FA, que foi secretada para o

periplasma, seja obtida através de choque osmótico. Após a extração da 
Gal-3/FA, sua concentração foi determinada e uma parte da Gal-3/FA foi purificada, dialisada e concentrada da mesma maneira que a galectina-3 humana recombinante. Em seguida, foram realizados ensaios de western blotting para confirmar a expressão e verificar a pureza da Gal-3/FA. Extratos de células CCR2 (controle positivo) e a Gal-3/FA foram separados por eletroforese em gel de poliacrilamida/SDS em condições redutoras e não redutoras e transferidos para a membrana de PVDF. Em seguida a membrana foi bloqueada e incubada com o anticorpo anti-galectina-3 M3/38. Após a lavagem, a membrana foi incubada com o anticorpo anti-IgG de rato conjugado a peroxidase e revelada. Em condições redutoras foi observada uma banda de aproximadamente $32 \mathrm{kDa}$ que corresponde a galectina-3 humana e uma banda de $75 \mathrm{kDa}$ que corresponde a Gal-3/FA. Nas condições não redutoras também se observou uma banda de aproximadamente 175 kDa que pode corresponder a um agregado de Gal3/FA. Nos extratos das células CCR2 foi observada uma banda com massa molecular aparente de aproximadamente $32 \mathrm{kDa}$, que corresponde a galectina-3 de camundongo (Figura 12A). A expressão da Gal-3/FA também foi analisada com o uso do anticorpo anti-fosfatase alcalina. Proteínas dos vetores pLIp6-GN (controle negativo) e pLIp5 (controle positivo) e a Gal-3/FA foram separadas por eletroforese em gel de poliacrilamida/SDS em condições redutoras e não redutoras, transferidos para a membrana de PVDF e analisadas com o anticorpo anti-fosfatase alcalina. Na Figura 12B em condições redutoras observa-se a banda de 45 kDa que corresponde a fosfatase alcalina e uma banda de $75 \mathrm{kDa}$ que corresponde a Gal-3/FA. As 
bandas de $32 \mathrm{kDa}(\mathrm{A})$ e $75 \mathrm{kDa}(\mathrm{B})$ encontradas parecem ser resultado da degradação da Gal-3/FA. Em condições não redutoras se observou a mesma banda de 175 kDa que indica como na Figura 12A a existência de Gal-3/FA dimérica.

A
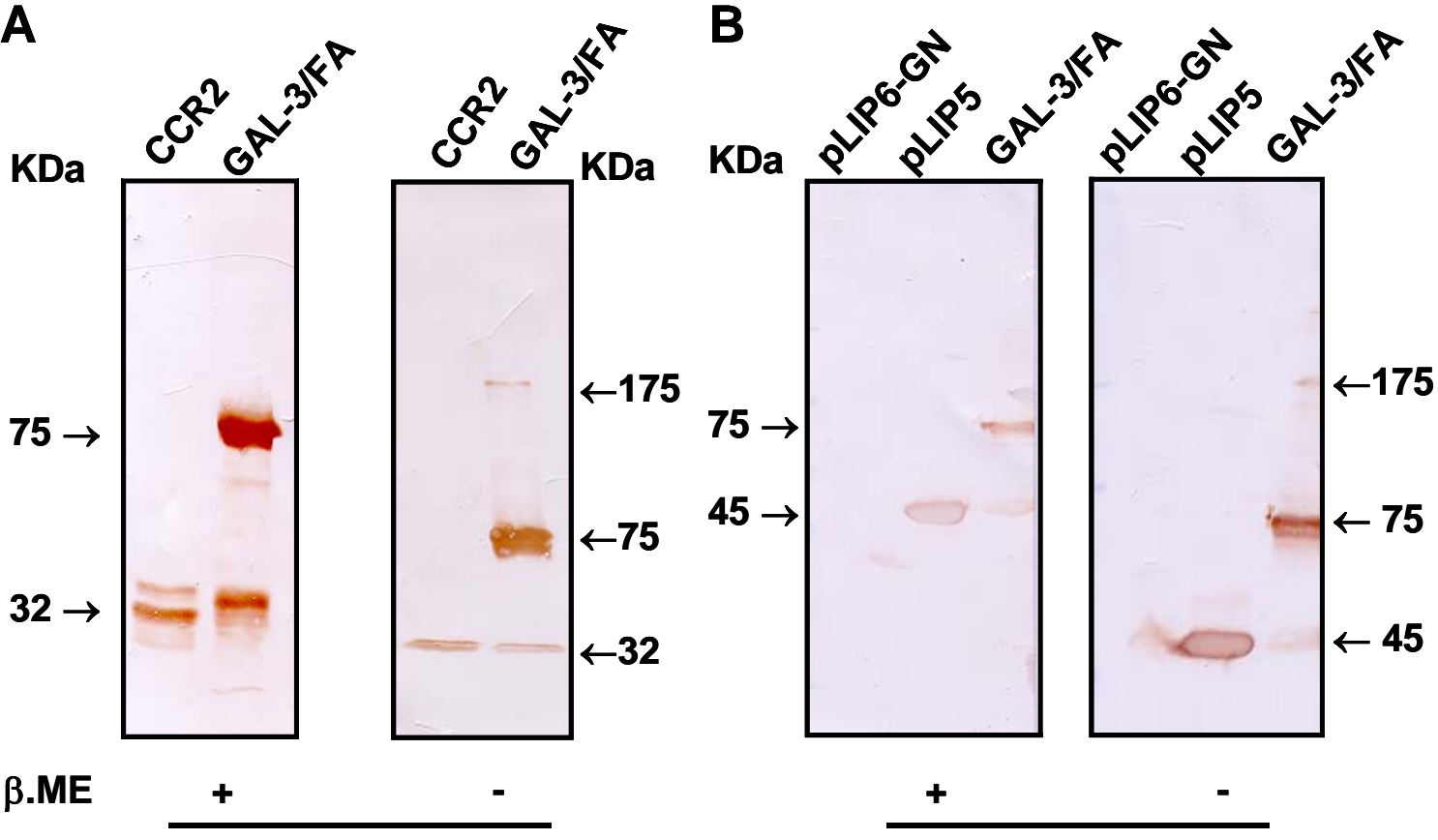

Anti-galectina-3

Anti-fosfatase alcalina

FIGURA 12 - Expressão da galectina-3 conjugada a fosfatase alcalina (Gal-3/FA). A expressão da Gal3/FA foi confirmada por western blotting. A - Extrato das células CCR2 (controle positivo) e a Gal-3/FA foram separadas em gel de poliacrilamida/SDS em condições redutoras e não redutoras, transferidas para membrana de PVDF e analisadas com o anticorpo monoclonal anti-galectina-3 (M3/38). A banda de 75 KDa corresponde a Gal-3/FA monomérica e a banda de $32 \mathrm{kDa}$ corresponde apenas a galectina-3. A banda de aproximadamente $175 \mathrm{kDa}$ corresponde possivelmente a forma dimérica Gal-3/FA. B- Também foram separadas amostras da proteína do vetor pLIp6-GN (controle negativo) e do vetor pLIp5 (controle positivo) que foram analisados com o anticorpo anti-fosfatase alcalina. A banda de $45 \mathrm{kDa}$ corresponde a fosfatase alcalina e a banda de $75 \mathrm{kDa}$ q indica a Gal-3/FA. A banda de $175 \mathrm{kDa}$ indica como em A a existência de Gal-3/FA dimérica. 


\section{6 - A LIGAÇÃO DA GAL-3/FA A LAMININA-1 É INIBIDA NA PRESENÇA DE LACTOSE}

A capacidade de ligação da Gal-3/FA a polilactosaminas também foi avaliada usando-se como substrato a laminina-1. O ensaio foi realizado como descrito em materiais e métodos. O gráfico mostra que a Gal-3/FA se ligou a laminina-1 e não ao BSA, de maneira dose dependente, e que a ligação foi inibida na presença de lactose (Figura 13). Este resultado confirma que o domínio de reconhecimento de carboidratos (CRD) da galectina-3, que está conjugada a fosfatase alcalina, tem atividade. A atividade enzimática da Gal-3/Fa também foi confirmada usando-se como substrato o $p$-nitrofenilfosfato. 


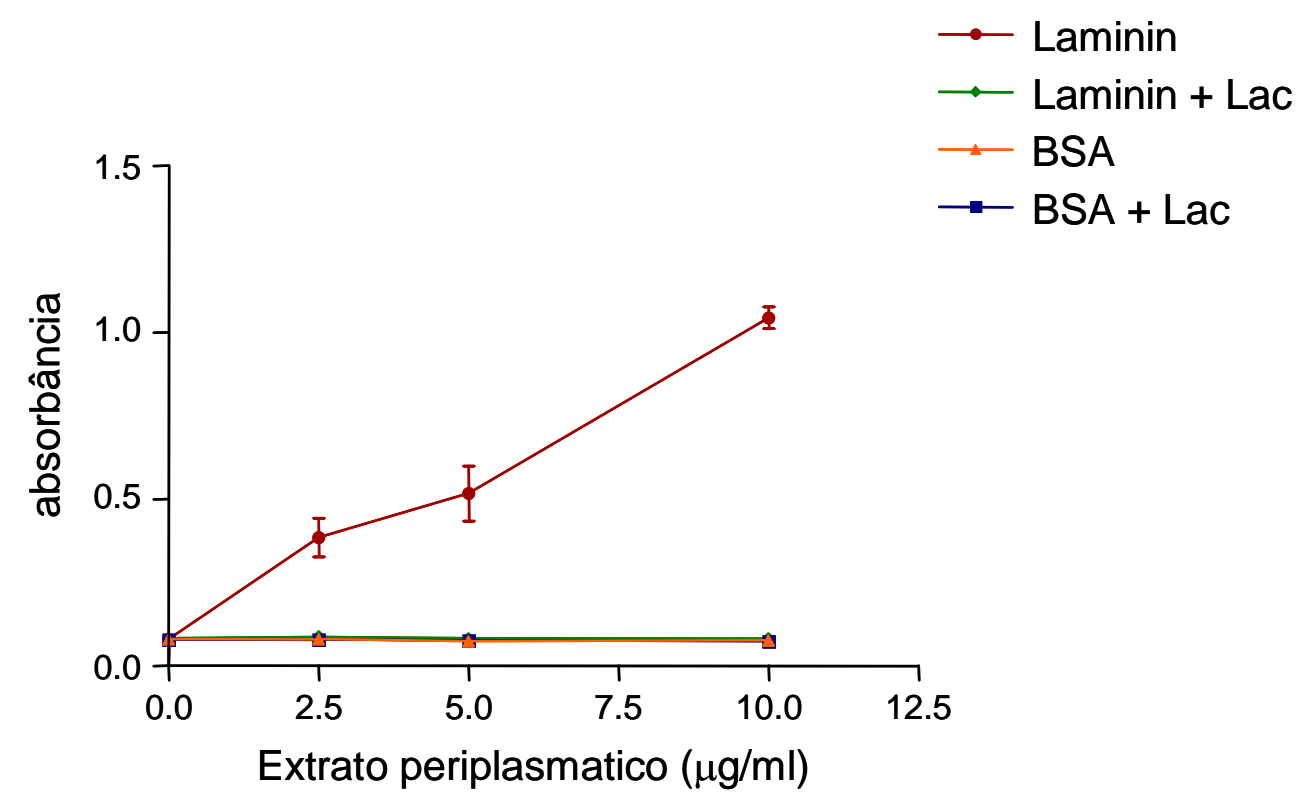

FIGURA 13 - A galectina-3 conjugada a fosfatase alcalina (Gal-3/FA) tem atividade de ligação inibida na presença de lactose e atividade enzimática de fosfatase alcalina. A- A atividade de ligação (funcionalidade do CRD) da Gal-3/FA foi avaliada em ensaio de ELISA. A placa foi sensibilizada com 10 $\mu \mathrm{g} / \mathrm{ml}$ de laminina-1, bloqueada com PBS/BSA $1 \%$ e incubada com concentrações crescentes do extrato periplasmático de Gal-3/FA na presença ou ausência de $100 \mathrm{mM}$ de lactose. Em seguida, a reação foi revelada com o substrato para fosfatase alcalina e a absorbância determinada a $405 \mathrm{~nm}$. A Gal-3/FA se ligou a laminina-1 de maneira dose-dependente e a sua ligação foi inibida na presença de lactose. Gal-3/FA possui atividade enzimática de fosfatase alcalina.

\section{7 - GAL-3/FA POSSUI A MESMA ESPECIFICIDADE QUE GALECTINA-3}

A especificidade da Gal-3/FA foi determinada através do ensaio de ligação direta a um painel que continha 100 glicanos. A tabela indica os 8 diferentes glicanos reconhecidos pela Gal-3/FA e a razão sinal/ruído observada está correlacionada com a afinidade da ligação. Os glicanos contendo di- ou trilactosaminas foram os ligantes preferenciais, como observado para galectina-3 humana ${ }^{160,161}$. Portanto, a fusão de galectina-3 com a enzima fosfatase alcalina não alterou a especificidade fina da lectina (Tabela V). 


\begin{tabular}{|c|c|c|}
\hline Glicanos & \begin{tabular}{|c|}
$\begin{array}{c}\text { Nome } \\
\text { comum }\end{array}$ \\
\end{tabular} & Sinal/ruído \\
\hline Gal $\alpha 3$ (Fuc $\alpha 2)$ Gal $\beta 4$ GlcNac & $\begin{array}{c}\text { B (tipo } \\
2 \text { ) }\end{array}$ & 25.93 \\
\hline Gal $\beta 4$ GIcNAc $\beta 3 G a l \beta 4 G|c N A c \beta 3 G a| \beta 4 G I c N A c$ & LN3 & 25.65 \\
\hline GalNAc $\alpha 3(F u c \alpha 2)$ Gal $\beta 4$ GlcNAc $\beta$ & $\begin{array}{l}\text { A (tipo } \\
2 \text { ) }\end{array}$ & 19.99 \\
\hline Neu5Ac $\alpha 3$ Gal $\beta 4 G I c N A c \beta 3 G a l \beta 4 G I c N A c \beta 3 G a l \beta 4 G I c N A c \beta$ & $\begin{array}{l}\text { 3'SiaLN- } \\
\text { LN-LN }\end{array}$ & 19.65 \\
\hline Gal $\beta 4 G I c N A c \beta 3 G a l \beta 4 G I c N A c \beta$ & LN2 & 12.63 \\
\hline Fuc $\alpha 2$ Gal $\beta 4$ GlcNAc $\beta 3$ Gal $\beta 4$ GIcNAc & $\begin{array}{l}\text { 2'F-Di- } \\
\text { LN }\end{array}$ & 10.19 \\
\hline Gal $\beta 4$ GIcNAc $\beta 3 G a l \beta 4 G \mid c \beta$ & LNnT & 7.45 \\
\hline Neu5Ac $\alpha 6$ Gal $\beta 4$ GIcNAc $\beta 4$ Gal $\beta 4 G I c N A c \beta$ & $\begin{array}{c}\text { 6'SLN- } \\
\text { LN }\end{array}$ & 7.12 \\
\hline
\end{tabular}

Tabela V. Ensaio de ligação direta de Gal-3/FA com diferentes glicanos em matriz preparada pelo Consortium for Functional Glycomics (NIGMS, core H http://glycomics.scripps.edu/CFGad.htmL) permitiu a definição da especificidade fina da proteína quimérica. Na tabela estão indicados os glicanos aos quais a molécula quimérica apresentou ligação de alta e média afinidade, determinadas pela razão sinal/ruído (alta afinidade > 10; média afinidade $<10$ ). O perfil de ligação é compatível com o de galectina-3 humana, mostrando que a quimerização da molécula não alterou sua capacidade de ligação. (LN, lactosamina)

\section{8 - A GAL-3/FA RECONHECE OLIGOSSACARÍDEOS N-LIGADOS DE PROTEÍNAS CELULARES}

Foram realizados ensaios de overlay para avaliar o uso da Gal-3/FA como sonda na identificação e análise da expressão e distribuição dos ligantes de galectina-3.

Galectina-3 reconhece preferencialmente polilactosaminas presentes em oligossacarídeos $\mathrm{N}$-ligados multiantenares, especialmente com ramificações $\beta 1 \rightarrow 6$. A inibição das manosidases I e II bloqueia a síntese de polilactosaminas contendo oligossacarídeos $N$-ligados. 
As células CCR2 e $\Sigma 12$ foram tratadas com $1 \mathrm{mM}$ de deoximanojirimicina ( $d M N$ ), um inibidor de $\alpha$-manosidase I, e em seguida a presença dos ligantes de galectina-3 foi avaliada usando-se a Gal-3/FA. Os extratos das proteínas tratadas com dMN foram separadas em gel de poliacrilamida/SDS em condições redutoras, transferidos para membrana de PVDF e analisados com as lectinas L-PHA e GNA e com Gal-3/FA. A lectina L-PHA reconhece glicoproteínas $N$-ligadas que contém ramificações $\beta 1 \rightarrow 6$ e foi usada como controle positivo. Como controle para o tratamento com dMN foi usada a lectina GNA que reconhece resíduos de alta-manose presentes em oligossacarídeos $N$-ligados. Como mostra a Figura 14 , L-PHA e Gal3/FA têm um padrão semelhante de reconhecimento de glicoproteínas nos extratos das células CCR2 e $\Sigma 12$. São reconhecidas principalmente 3 glicoproteínas com massa molecular aparente de 250, 195 e 82 kDa. Após o tratamento com dMN observa-se uma diminuição significativa da reatividade de L-PHA e Gal-3/FA, indicado pela diminuição da intensidade dessas 3 bandas. Por outro lado, há o aparecimento de uma banda de 150 kDa reconhecida por GNA após o tratamento com dMN, mostrando a eficiência do tratamento. 


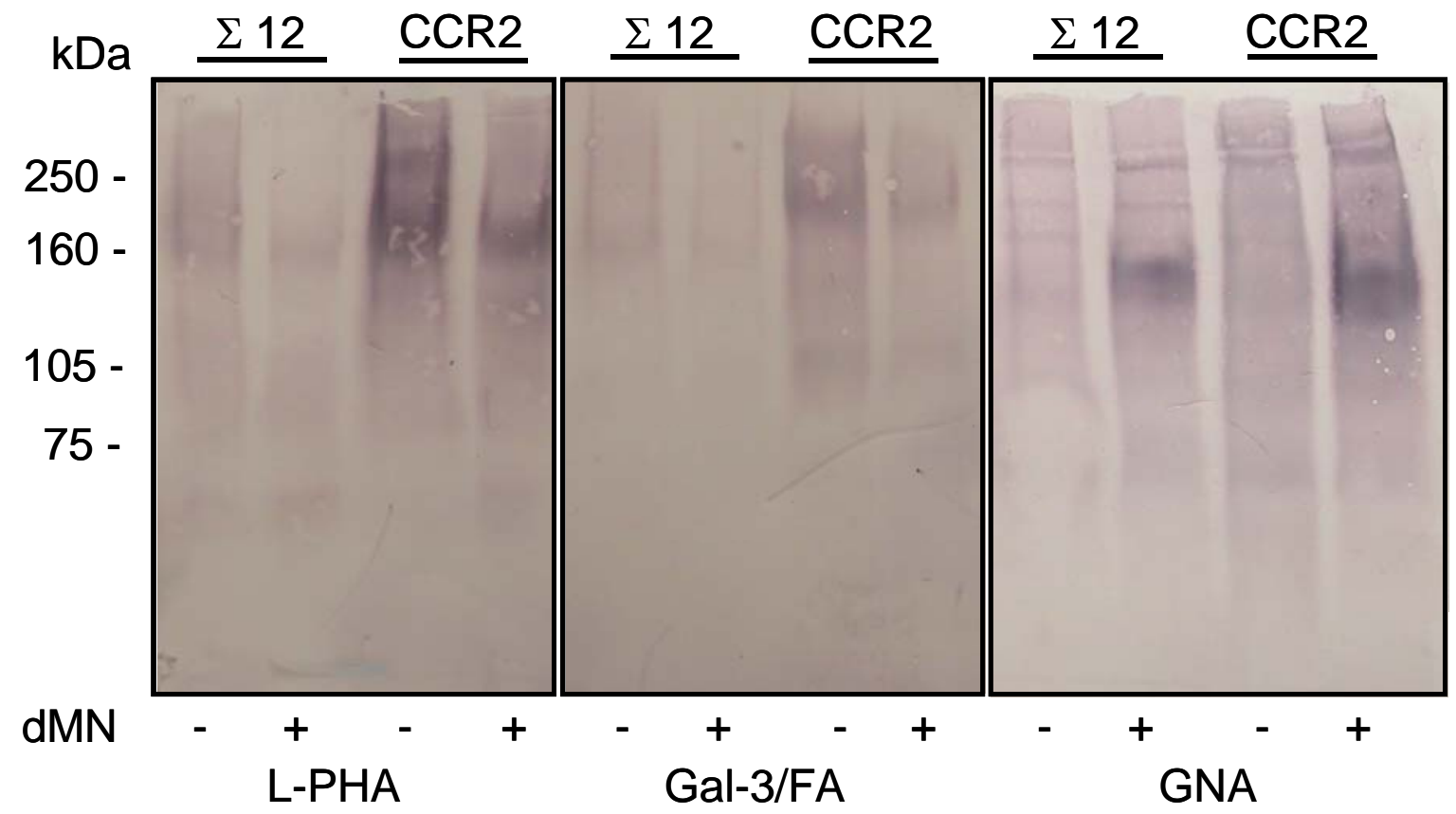

FIGURA 14 - Galectina-3 reconhece oligossacarídeos $\mathbf{N}$-ligados de proteínas celulares. As células CCR2 e $\Sigma 12$ foram tratadas com 1mM of deoximanojirimicina (dMN) por 24 horas em condições de cultura. Em seguida, o extrato protéico dessas células foi separado em gel de poliacrilamida/SDS, transferido para membrana de PVDF e incubado com $30 \mu \mathrm{g} / \mathrm{ml}$ de Gal-3/FA, com L-PHA ou com GNA por 16 horas a $4^{\circ} \mathrm{C}$. A membrana incubada com L-PHA foi incubada com anticorpo conjugado a biotina e em seguida com estreptoavidina conjugada a fosfatase alcalina. A membrana com GNA foi incubada com o anticorpo anti-digoxigenina conjugada a fosfatase alcalina. A revelação foi feita com o substrato NBT/BCIP. A reatividade de L-PHA e Gal-3/FA diminuiu após o tratamento com dMN. Por outro lado, como esperado, a inibição da $\alpha$-manosidase I, levou ao aumento de glicoproteínas contendo resíduos de alta-manose, reconhecidas pela lectina GNA.

Num segundo experimento, as células B16F10 e $\Sigma 12$ foram tratadas com 1mM de swainsonina (SW), um inibidor de $\alpha$-manosidase II (Figura 15). Como descrito anteriormente na Figura 14, o mesmo padrão de reconhecimento observado para L-PHA foi observado para Gal-3/FA e houve diminuição significativa da reatividade após o tratamento com SW. Esses resultados mostram que além de ser útil em ensaios de overlay para identificar os ligantes de galectina-3, que a interação entre a galectina-3 e seus ligantes é pelo menos em parte dependente de $N$-glicosilação. 


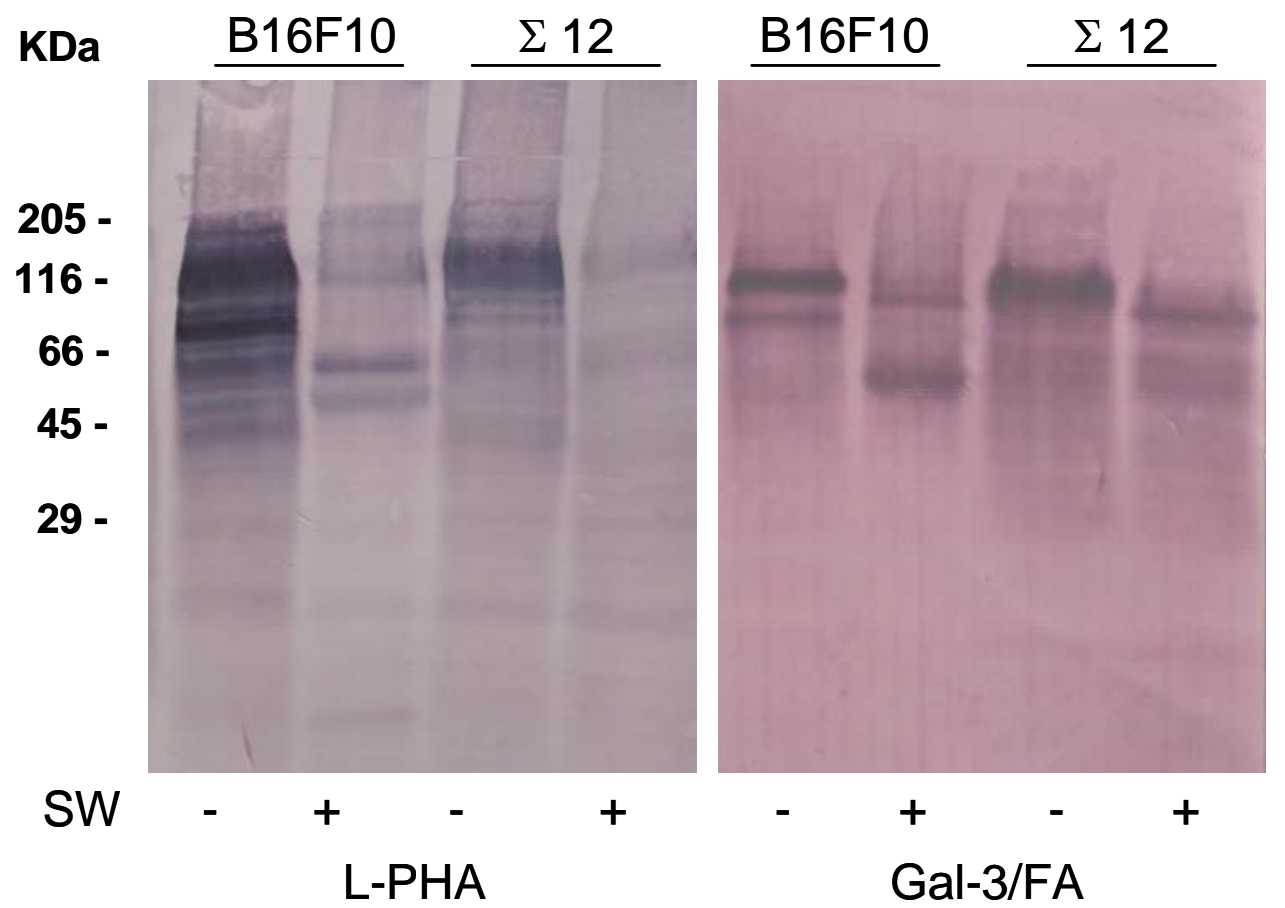

FIGURA 15 - Galectina-3 reconhece oligossacarídeos $\mathbf{N}$-ligados de proteínas celulares. As células B16F10 e $\Sigma 12$ foram tratadas com 1mM de swainsonina por 72 horas em condições de cultura. Em seguida, o extrato protéico dessas células foi separado em gel de poliacrilamida/SDS, transferido para membrana de PVDF e incubado com $30 \mu \mathrm{g} / \mathrm{ml}$ de Gal-3/FA ou com L-PHA por 16 horas a $4^{\circ} \mathrm{C}$. A membrana incubada com L-PHA foi incubada com anticorpo conjugado a biotina e em seguida com estreptoavidina conjugada a fosfatase alcalina. A revelação foi feita com o substrato NBT/BCIP. Os resultados mostram que o reconhecimento de Gal-3/FA é dependente pelo menos em parte do processamento de oligossacarídeos $N$-ligados.

\section{9 - O RECONHECIMENTO DOS LIGANTES DE GALECTINA-3 PELA GAL-3/FA NÃO É SENSÍVEL A DESIALILAÇÃO}

Nós também avaliamos se o reconhecimento dos ligantes de galectina-3 pela Gal-3/FA é mascarado por resíduos de ácido síalico em glicoproteínas. Sabe-se que a maturação de timócitos é acompanhada pelo aumento da sialilação de moléculas presentes na superfície celular. Por isso, foram preparados extratos de timócitos que foram tratados ou não com 100 $\mathrm{mU}$ de neuraminidase de Arthrobacter ureafaciens, enzima que retira 
resíduos de ácido siálico. Em seguida, os extratos foram separados em gel de poliacrilamida/SDS em condições redutoras, transferidos para membrana de PVDF e analisados com a lectina PNA e com Gal-3/FA. PNA reconhece glicoproteínas contendo resíduos de $\operatorname{Gal} \beta 1 \rightarrow 3 G$ alNAc $\alpha$, os quais são expostos nos timócitos após o tratamento com ácido siálico. A Figura 16 mostra que a Gal-3/FA reconhece vários glicoconjugados presentes em timócitos e que a retirada dos resíduos de ácido siálico presentes nas glicoproteínas de timócitos não aumentou o reconhecimentodos dos ligantes de galectina-3 pela Gal-3/FA. 


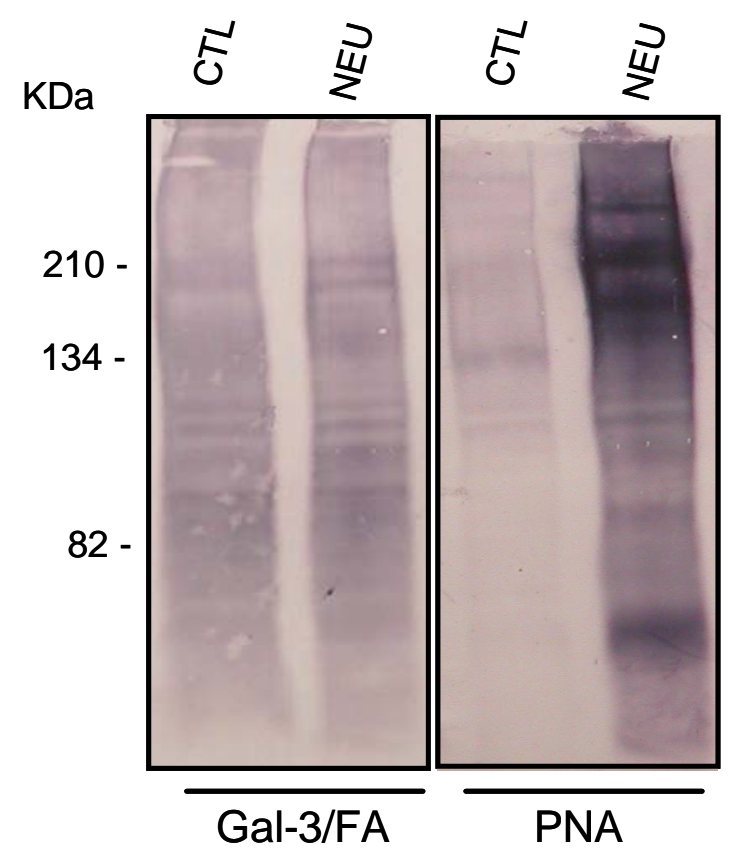

FIGURA 16- A presença de resíduos de ácido siálico não interfere na interação de Gal-3/FA com os ligantes de galectina-3 presentes em timócitos. Extratos protéicos de timócitos foram tratados ou não com $100 \mathrm{mU}$ de neuraminidase de Arthrobacter ureafaciens por $1 \mathrm{~h}$ a $37^{\circ} \mathrm{C}$. Após o tratamento, os extratos foram separados em gel de poliacrilamida/SDS sob condições redutoras, transferidos para membrana de PVDF e analisados com as lectinas Gal-3/FA e PNA. PNA foi usado como controle, demonstrando a eficiência do tratamento com neuraminidase. A desialilação não aumentou a reatividade de Gal-3/FA, mostrando que resíduos de ácido siálico não mascaram ligantes de galectina-3 presentes nos timócitos.

\subsection{0 - REAÇÃO COM GAL-3/FA EM TISSUE-ARRAY}

O nosso objetivo é analisar a presença e distribuição dos ligantes de galectina-3 em tecidos normais e na sua contraparte tumoral e avaliar o seu significado biológico. Para isso, utilizamos lâminas de tissue-array, que contém inúmeros tecidos normais e de origem tumoral. Após as lâminas terem passado pelo processo descrito em materiais e métodos, as lâminas foram incubadas com Gal-3/FA na presença ou ausência de 100 mM de lactose. Os resultados mostraram que a lactose inibiu a ligação de Gal-3/FA 
aos ligantes de galectina-3 presentes nos tecidos, confirmando a especificidade da molécula já avaliada em ensaios de ELISA (Figura 13). controle negativo foi feito incubando-se a lâmina com BSA 1\%. Em seguida, o padrão de marcação de Gal-3/FA foi avaliado em diferentes tecidos presentes no tissue-array.
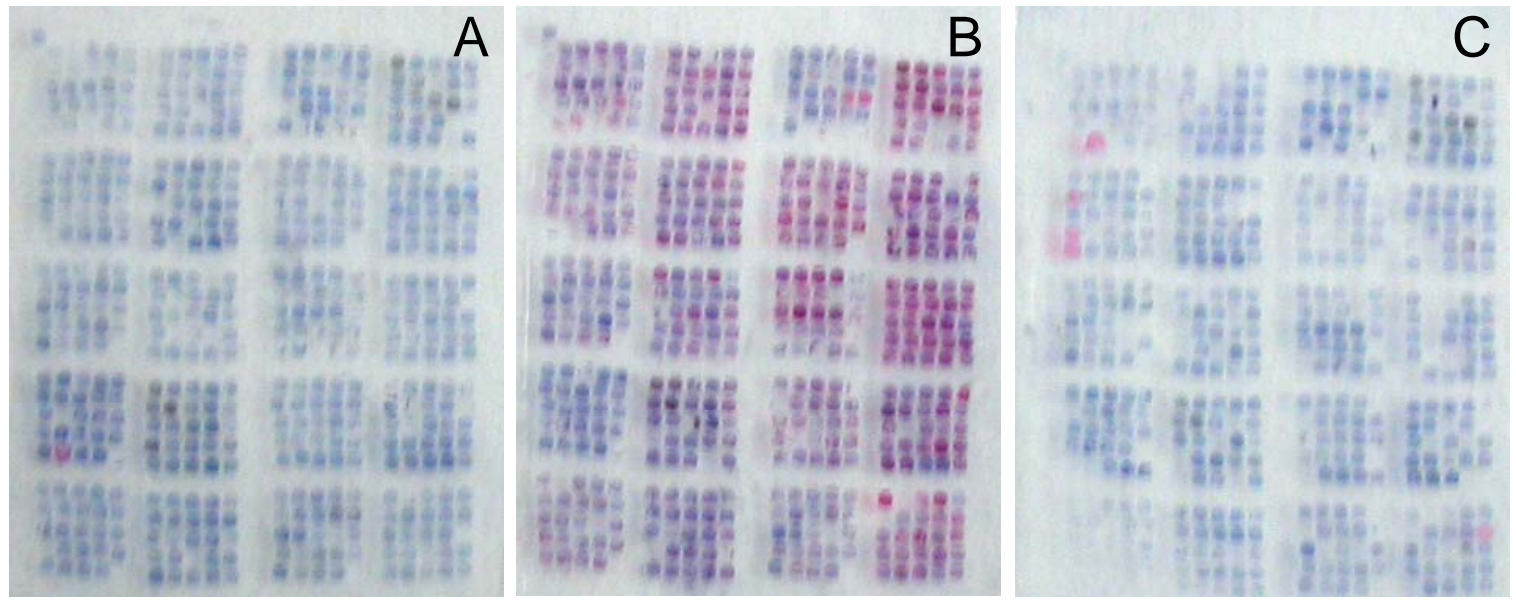

FIGURA 17- Reação de padronização com a Gal-3/FA em lâminas de tissue-arrays. As lâminas de tissue-arrays foram incubados com a Gal-3/FA na ausência (B) ou presença de $100 \mathrm{mM}$ de lactose (C) por 20 horas a $4^{\circ} \mathrm{C}$. Em seguida foram reveladas com substrato para fosfatase alcalina e coradas com hematoxilina. Observa-se que a lactose inibiu a ligação da Gal-3/FA aos ligantes de galectina-3 presentes nos tecidos, indicando a especificidade da molécula. $O$ controle negativo foi feito incubando-se a lâmina com BSA 1\% (A). 


\subsection{1 - EXPRESSÃO DOS LIGANTES DE GALECTINA-3 EM TUMORES HUMANOS}

No tissue-array existiam tecidos de várias origens: carcinoma de próstata, mama, pâncreas; melanoma, glioblastoma, retinoblastoma, glioma, carcinoma epidermóide de cabeça e pescoço e carcinóide. Os tecidos que apresentaram maior representatividade estão sendo mostrados na Figura 18.

O padrão de marcação de Gal-3/FA no carcinoma de mama ductal infiltrativo se correlacionou com o grau histológico do tumor. Em tumores bem diferenciados, a marcação de Gal-3/FA foi forte, delineando a superfície apical de células epiteliais transformadas (Figura 18A). A marcação das células epiteliais diminuiu significantemente em tumores pouco ou moderadamente diferenciados (Figura 18B). No entanto, a marcação do estroma foi intensa e associada ao endotélio e a células mononucleares e polimorfonucleares. O mesmo padrão foi observado no adenocarcinoma de próstata. Os casos analisados foram Gleason 3 ou Gleason 4-5. Nos casos Gleason 3, as células epiteliais apresentaram ligantes de galectina-3 no citoplasma e na membrana apical. Pode-se observar também a presença de glicoproteínas no lúmen acinar, entretanto o estroma não mostrou reatividade (Figura 18C). Nos tumores menos diferenciados, as células epiteliais apresentaram marcação fraca, enquanto as células estromais, como células endoteliais e leucócitos, mostraram reatividade intensa com Gal-3/FA. Em adenocarcinomas de pâncreas, o padrão de marcação não indicou o grau histológico como o fez nos carcinomas de mama e de próstata. No entanto, também foi observado diminuição da marcação apical 
nos adenocarcinomas de pâncreas (Figura 18D). Em gliomas, as células tumorais não apresentaram reatividade, mas quando presentes, o infiltrado inflamatório apresentou forte marcação (Figura 18E). Em melanomas, a reatividade das células tumorais foi variável, mas manteve o padrão observado nos tumores descritos acima. O estroma dessas células estava fortemente marcado (Figura 18F). 


\section{FIGURA 18}




\subsection{2 - ANÁLISE DA EXPRESSÃO E DA DISTRIBUIÇÃO DOS LIGANTES} DE GALECTINA-3 EM TECIDOS DE CAMUNDONGO - LOCALIZAÇÃO NO TIMO E EM SARCOMAS EXPERIMENTAIS

Já foi mostrado que galectina-3 é encontrada em compartimentos específicos do timo ${ }^{149}$. Analisamos a expressão de galectina-3 no timo de camundongos (Figura 19A) e em sarcomas murinos localmente invasivos (Figura 19E), por imunoistoquímica (coloração castanha indica positividade). Galectina-3 foi encontrada em células esparsas presentes no córtex (C) e na medula (M) do timo. Quando o mesmo tecido foi analisado com a lectina vegetal (L-PHA) (Figura 19C), que reconhece potenciais ligantes de galectina-3, observamos que houve marcação intensa (coloração castanha) na medula, e em áreas subcapsulares do córtex. O padrão de reatividade com a molécula quimérica (Gal-3/FA, em $C$ e D) é bastante distinto (coloração avermelhada mostra positividade), indicando que os principais ligantes de galectina-3 estão de fato localizados no córtex tímico, onde se encontram os timócitos imaturos. O tratamento do timo com neuraminidase não aumentou a reatividade da Gal-3/FA, mostrando que o tratamento não revelou a presença de novos ligantes para galectina-3, como já mostrado nos extratos protéicos do timo (dado não mostrado).

No sarcoma murino (Figura $19 \mathrm{E}-\mathrm{H}$ ), mostramos que as células tumorais (s) acumulam galectina-3 (E), sendo altamente reativas a L-PHA (F). As fibras musculares (m) não são reativas ao anticorpo ou a L-PHA aparentemente (E e F, respectivamente). Ligantes de galectina-3 propriamente dita são encontrados nas células tumorais ( $G$ e $H$ ), que 
apresentam um comportamento localmente invasivo, migrando pelas membranas basais, enriquecidas em laminina, das fibras musculares. A reatividade citoplasmática a Gal-3/FA reforça a noção de que a célula tumoral expressa glicoconjugados reativos a esta lectina. Mais uma vez o padrão de reconhecimento da Gal-3/FA e de L-PHA foram bem diferentes. 

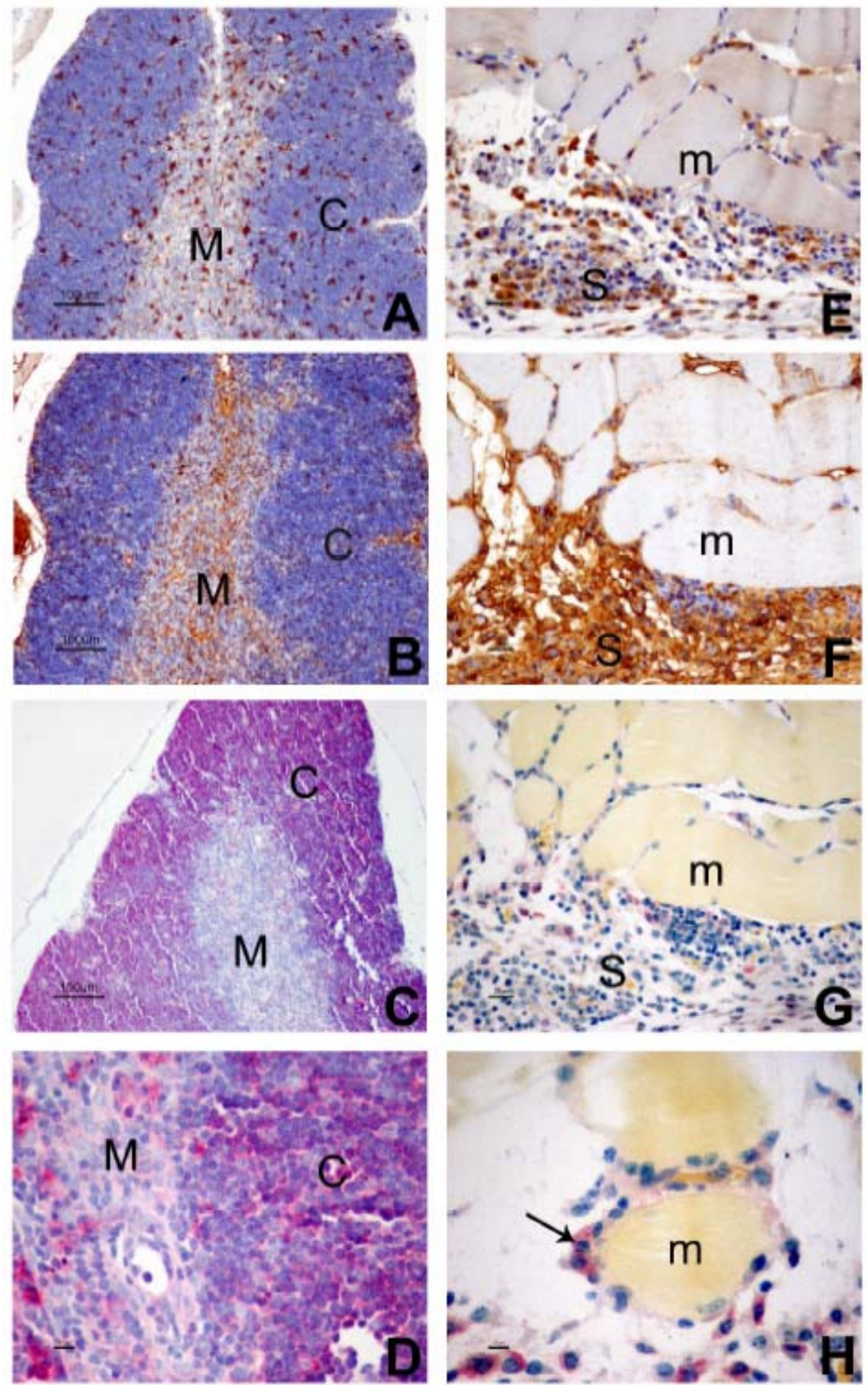

FIGURA 19. Distribuição de galectina-3 e dos seus ligantes em tecidos murinos. Galectina-3 foi encontrada em células esparsas no córtex (C) e na medula (M) (A). A lectina vegetal L-PHA (B) mostrou reatividade intensa na medula e em áreas subcapsulares do córtex. Os principais ligantes de galectina-3 foram encontrados no córtex (C e D). No sarcoma murino, as células tumorais (s) acumularam galectina-3 (E) e apresentaram alta reatividade a L-PHA (F). As fibras musculares $(\mathrm{m})$ não foram reativas ao anticorpo e nem a L-PHA. Os ligantes de galectina-3 foram encontrados em células tumorais (G e H) que apresentaram comportamento localmente invasivo (vide seta). (Barras, de A-C e E-G, equivalem a $100 \mu \mathrm{M}$; D e H, $10 \mu \mathrm{M}$ ) 


\subsection{3 - A ADIÇÃO DE GALECTINA-3 EXÓGENA AUMENTA A MIGRAÇÃO DE CÉLULAS $\Sigma 12$}

Células de sarcoma que expressam galectina-3 são mais migratórias em superfícies de laminina-1 do que células que não expressam galectina-3 (Melo e col., em preparação - Anexo I). Nós propomos que essas células estejam secretando galectina-3, a qual estaria modulando o processo de deadesão e assim, aumentando a capacidade migratória dessas células. Sabese que galectina-3 é secretada para o meio extracelular na presença de seus ligantes, como a fetuína. Nós observamos que as células CCR2 secretam galectina-3 para o meio extracelular mesmo na ausência dos seus ligantes (dado não mostrado). Para avaliar o efeito da galectina-3 exógena no processo de migração celular, células $\Sigma 12$ foram plaqueadas em lamínulas circulares, onde foi feito um risco, permitindo dessa maneira, que as células da borda migrassem para os espaços vazios. No momento do risco, as células $\Sigma 12$ foram incubadas na presença ou ausência de laminina-1 e na ausência ou presença de galectina-3 por 24 h. As células incubadas na presença de laminina-1 e também de galectina-3 migraram 3 vezes mais que as células controle $(p<0,001)$ (Figura 20). As células incubadas somente com laminina-1 não apresentaram aumento de migração nesse período. As células também foram incubadas na presença de $50 \mathrm{mM}$ de lactose. $\mathrm{O}$ gráfico mostra que a lactose inibiu a migração das células $\Sigma 12$, indicando que o efeito da galectina-3 sobre o processo de migração celular das células $\Sigma 12$ é carboidrato-dependente $(p<0,001)$ (Figura 21). 
FIGURA 20 




FIGURA 21. A adição de lactose inibiu o efeito de galectina-3 sobre a migração das células $\Sigma 12$. As células $\Sigma 12$ foram plaqueadas em lamínulas circulares. Após 24 horas, estas células foram incubadas na ausência ou presença de $10 \mu \mathrm{g} / \mathrm{mL}$ de laminina-1, na ausência ou presença de $20 \mu \mathrm{g} / \mathrm{mL}$ de galectina-3 e na ausência ou presença de $50 \mathrm{mM}$ de lactose por 24 horas. Em seguida, estas células foram fixadas, permeabilizadas e coradas com DAPI. A quantificação das células migratórias foi feita com o programa Eclipse Net. As análises foram feitas usando o método ANOVA, seguido do teste $t$ de Bonferroni para múltiplas comparações, usando-se o software Prism 3.0. A lactose inibiu o efeito de galectina-3 sobre a migração das células $\Sigma 12$, mostrando que o seu efeito é carboidrato-dependente CRD $(p<0,001)$.

\subsection{4 - GALECTINA-3 É ENCONTRADA NOS COMPLEXOS FOCAIS}

Os complexos focais são regiões especializadas da membrana plasmática localizados na parte ventral da célula que desempenham papel importante no controle do espraiamento e da migração celular ${ }^{36,38}$. Como dito anteriormente, a galectina-3 modula positivamente o processo de migração celular. Baseado nesses dados, o objetivo desse ensaio foi avaliar se a galectina-3 pode ser encontrda nos complexos focais. Após aderidas, as células $\Sigma 12$ foram incubadas na ausência ou presença de galectina-3 por 15 min e $24 \mathrm{~h}$. Em seguida, os complexos focais foram isolados e analisados por SDS/PAGE. A Figura 22A e 22C mostra que a galectina-3 é encontrada 
nos complexos focais de células $\Sigma 12$ tratadas por 15 min e $24 \mathrm{~h}$, respectivamente. Observa-se que na presença de $50 \mathrm{mM}$ de lactose houve diminuição da galectina-3 monomérica nos complexos focais. A galectina-3 também foi encontrada nos complexos focais das células CCR2 (dado não mostrado). A galectina-3 recombinante (rGal-3) foi usada como controle positivo. Também foi avaliada a presença de proteínas que compõe os complexos focais como integrinas, FAK e SHP-2. A figura 22B mostra o recrutamento de SHP-2 para os complexos focais na presença de galectina3 , e que este recrutamento não foi inibido por lactose. As figuras $22 \mathrm{D}$ e $22 \mathrm{E}$ indicam que tanto $\beta 1$ integrina como FAK estão presentes nos complexos focais das células $\Sigma 12$ incubadas ou não com galectina-3. Podemos observar a diminuição de FAK nos complexos focais nas células que foram incubadas com galectina-3 por $24 \mathrm{~h}$.

\subsection{5 - GALECTINA-3 SE LIGA NA SUPERFÍCIE DE CÉLULAS $\Sigma 12$}

As células $\Sigma 12$ foram tripsinizadas e lavadas com meio com $10 \%$ de SFB para inativação da tripsina e recomposição da membrana plasmática. Após 30 min, as células foram incubadas com $20 \mu \mathrm{g} / \mathrm{mL}$ de galectina-3 em meio DMEM sem soro em solução por $1 \mathrm{~h}$ a $37^{\circ} \mathrm{C}$. Em seguida, as células foram lavadas e incubadas com o anticorpo anti-galectina-3 M3/38 e analisadas por citometria de fluxo. Os histograms mostram que a galectina-3 se ligou na superfície das células $\Sigma 12$, indicando a presença de vários ligantes de galectina-3 na superfície dessas células (Figura 23). A galectina- 


\section{3 presente nos complexos focais poderia estar interagindo as integrinas,} receptores que fazem parte destes complexos.

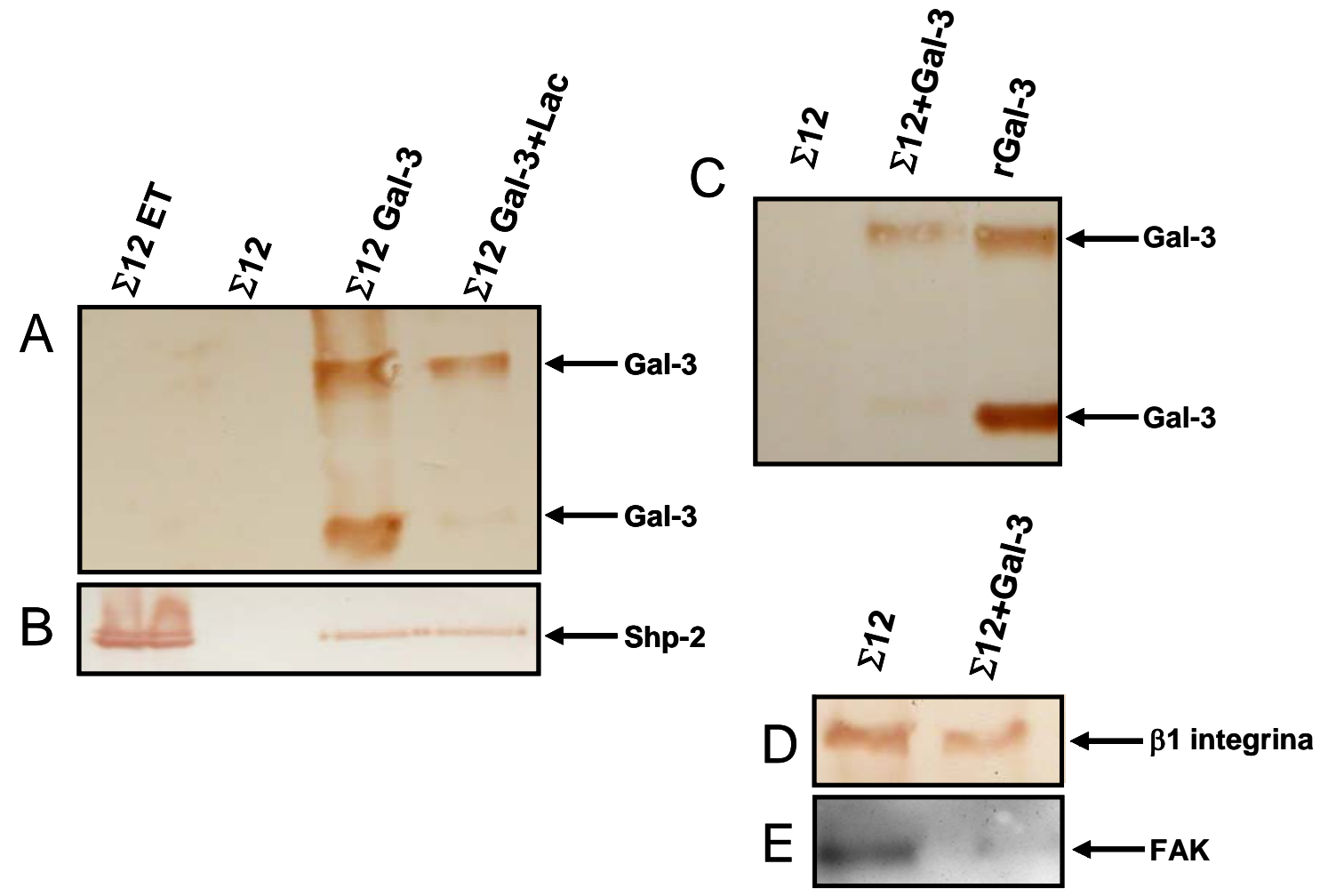

FIGURA 22. Galectina-3 foi encontrada nos complexos focais. Células $\Sigma 12$ foram incubadas na ausência ou presença de $20 \mu \mathrm{g} / \mathrm{mL}$ de galectina-3 por $24 \mathrm{~h}$ e por 15 min também na presença de lactose. Em seguida, seus complexos focais foram isolados e os extratos enriquecidos com complexos focais foram separados em eletroforese por SDS-PAGE sob condições redutoras, transferidos para membrana de PVDF e incubados com anticorpo monoclonal anti-galectina-3, anti-SHP-2, anti-FAK e anti- $\beta 1$ integrina. (A e C) Galectina-3 foi encontrada nos complexos focais das células $\Sigma 12$ incubadas com galectina-3 por 15 min e 24 h, respectivamente. Galectina-3 recombinante foi usada como controle positivo.(A) Observou-se a diminuição de galectina-3 monomérica na presença de lactose. (B) SHP-2 foi recrutado para os complexos focais de células $\Sigma 12$ incubadas com galectina-3 por 15 min, efeito que não foi inibido pela lactose. (D) As células $\Sigma 12$ mantém o padrão de expressão de $\beta 1$ integrina na presença de galectina-3. (E) Na presença de galectina-3 houve diminuição de FAK nos complexos focais. 


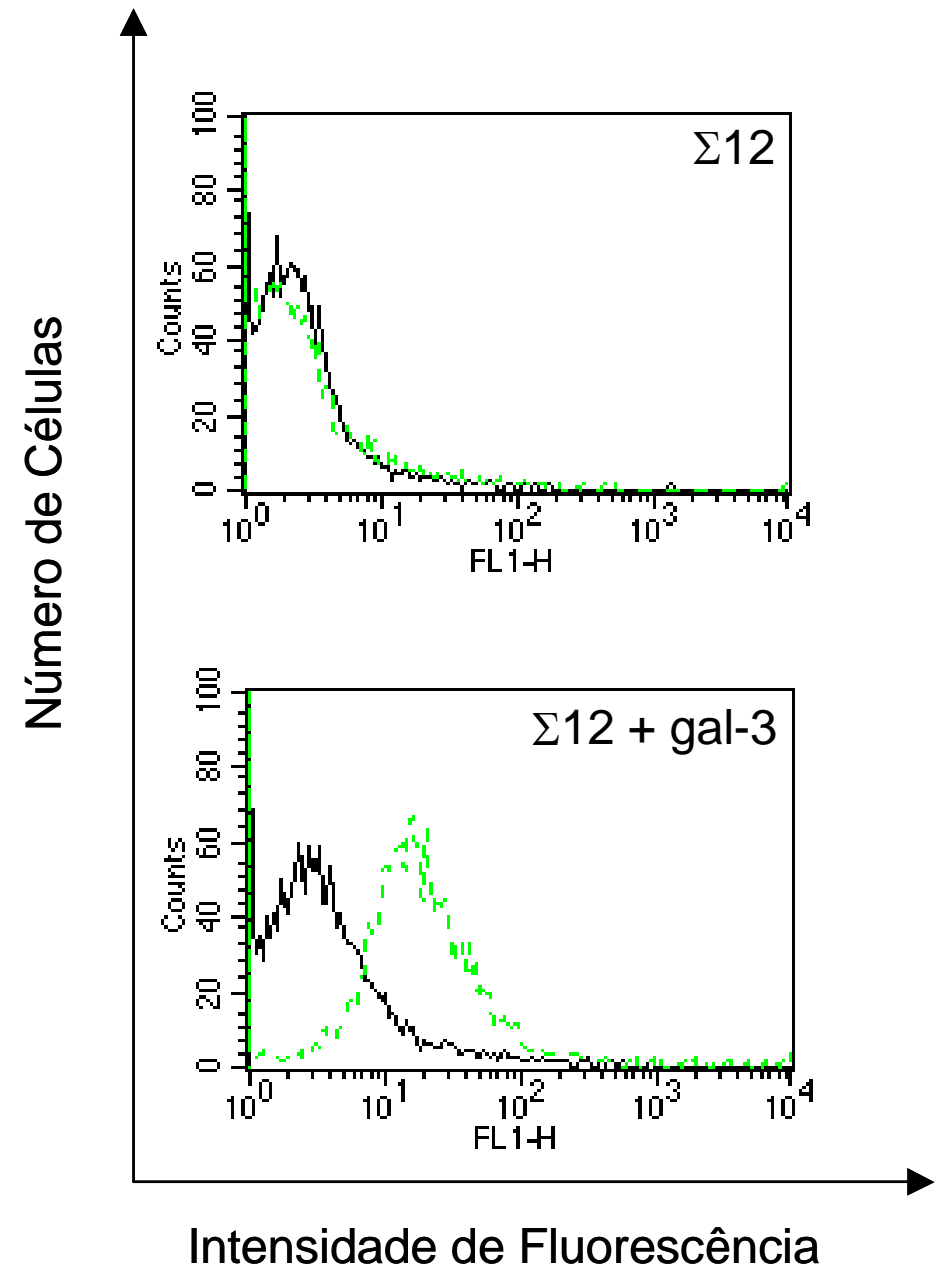

FIGURA 23. Galectina-3 se liga a glicoconjugados presentes na superfície das células $\Sigma 12$. Células $\Sigma 12$ foram tripsinizadas e tratadas ou não com $20 \mu \mathrm{g} / \mathrm{mL}$ de galectina-3 por 1 hora a $37^{\circ} \mathrm{C}$. Em seguida, essas células foram lavadas com PBS e incubadas com o anticorpo anti-galectina-3 e anti-rato conjugado a FITC. A presença de galectina-3 na superfície das células $\Sigma 12$ foi avaliada por citometria de fluxo. A galectina-3 se ligou a superfície das células $\Sigma 12$.

\subsection{6 - GALECTINA-3 INTERAGE DIRETAMENTE COM $\beta 1$-INTEGRINA}

Dados da literatura mostram que galectina-3 se liga a glicoproteínas que contém polilactosaminas presentes na superfície de várias células e na matriz extracelular ${ }^{162-164}$. Como mostra a Figura 23, galectina-3 se liga a várias moléculas presente na superfície das células $\Sigma 12$. 
Existem evidências que mostram que entre esses receptores de superfície estão as integrinas. As integrinas são substratos para glicosiltransferases específicas, como a Mgat5, enzima responsável pela biosíntese de resíduos tri- e tetra-antenares presentes nas integrinas (ramificações do tipo $\beta 1 \rightarrow 6$ ), os quais são ligantes de galectina-3. De fato, Ochieng e col mostraram que a galectina-3 interage indiretamente com integrinas ${ }^{163}$. Na Figura 24 nós mostramos que galectina-3 se liga diretamente a $\beta 1$ integrina. Extratos protéicos de células CCR2 foram imunoprecipitados com anticorpo anti- $\beta 1$ integrina. Os imunoprecipitados foram separados por SDS-PAGE, transferidos para membrana de PVDF e analisados com anticorpo anti- $\beta 1$ integrina e com a molécula quimérica Gal3/FA. O extrato total (A) mostra que a Gal-3/FA se liga a outra glicoproteína com massa molecular aparente de aproximadamente $75 \mathrm{kDa}$. 


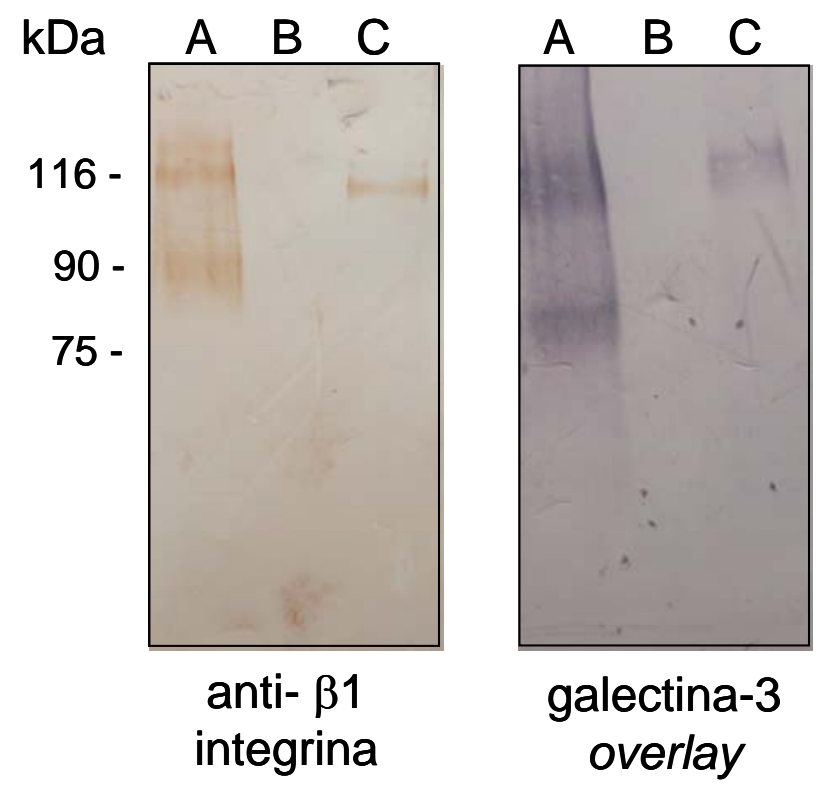

FIGURA 24. Galectina-3 interage diretamente com $\beta 1$ integrina. Extratos protéicos das células CCR2 foram imunoprecipitados com anticorpo controle (B) ou com anticorpo policlonal anti- $\beta 1$ integrina (C), separados por eletroforese em gel de SDS-PAGE, transferidos para membrana de PVDF e analisados com anticorpos anti- $\beta 1$ integrina e com a galectina-3 conjugada a fosfatase alcalina (Gal-3/FA). As bandas reconhecidas pelo anticorpo anti- $\beta 1$ integrina correspondem as formas matura e imatura do polipeptídeo. Gal-3/FA reconheceu 3 bandas, 2 delas também reconhecidas pelo anticorpo anti-b1 integrina e uma banda de $75 \mathrm{kDa}$.

\subsection{7 - A ADIÇÃo DE GALECTINA-3 EXÓGENA DIMINUIU A PRESENÇA DE FAK FOSFORILADO NOS COMPLEXOS FOCAIS}

Células de origem mesenquimal que expressam galectina-3 são mais migratórias em superfícies de laminina-1 do que células que não expressam galectina-3 (Melo e col., em preparação - Anexo I). Porém, o mecanismo ainda não é conhecido.

Para que as células migrem é necessário um processo integrado que requer a contínua e coordenada montagem e desmontagem dos complexos focais. Várias proteínas estão envolvidas na regulação do turnover dos complexos focais, entre elas FAK ${ }^{127}$.

Com o objetivo de avaliar a distribuição e fosforilação de FAK nas células $\Sigma 12$ (que não expressam galectina-3) na presença de galectina-3 
exógena, estas células foram plaqueadas em lamínulas circulares e após 48 h foi feito um risco para retirada da monocamada de células da lamínula. Nós observamos que as células em estado estacionário apresentaram acúmulo de FAK fosforilado nos complexos focais (dado não mostrado). Após 15 min, as células incubadas com galectina-3 apresentaram diminuição da fosforilação de FAK (em verde) (Figura 25 A), o que se tornou mais evidente após 60 min (Figura 25 B). A diminuição de FAK fosforilado nos complexos focais levou a reorganização do citoesqueleto, como indicado pela diminuição de fibras de estresse inseridas nos complexos focais (em vermelho) e a formação de ruffles de membrana. Na presença de lactose não observamos diminuição da fosforilação de FAK nos complexos focais, indicando que o efeito de galectina-3 é carboidrato-dependente. 
FIGURA 25 A 
FIGURA 25 B 


\subsection{8 - A ADIÇÃO DE GALECTINA-3 ALTERA O PADRÃO DE FOSFORILAÇÃO DE PROTEÍNAS PRESENTES NOS COMPLEXOS FOCAIS}

Durante a montagem e desmontagem dos contatos focais tem-se a fosforilação e desfosforilação de várias proteínas do citoesqueleto. A fosforilação de tirosinas é controlada pela ação de proteínas tirosinoquinases e proteínas tirosino-fosfatases ${ }^{46,165}$. Estudos usando tirosinoquinases ou inibidores de tirosino-fosfatases sugerem que a diminuição da fosforilação de tirosinas leva a desestabilização das placas de adesão focal ${ }^{37,166}$. Para avaliar o papel das fosfatases na modulação da migração de fibroblastos na presença de galectina-3, essas células foram tratadas com ortovanadato, inibidor inespecífico de fosfatases. $\mathrm{Na}$ presença de ortovanadato observamos aumento da fosforilação das tirosinas em todas as situações, indicando a eficiência do tratamento com ortovanadato. $\mathrm{Na}$ presença de galectina-3 observamos a formação de lamelipódios e de ruffles de membrana após 15 min e 60 min, sugerindo um padrão mais migratório. Também observamos que as células incubadas com galectina-3 apresentaram aumento da fosforilação de proteínas presentes nos complexos focais As células tratadas com galectina-3 mais ortovanadato apresentaram diminuição do padrão migratório após 15 e 60 min, com inibição da formação dos lamelipódios. 
FIGURA 26 A 
FIGURA 26 B 


\subsection{9 - Shp-2 É RECRUTADO PARA OS COMPLEXOS FOCAIS NA PRESENÇA DE GALECTINA-3 EXÓGENA}

Células em migração devem ter a capacidade de desfosforilar FAK para que ocorra a desmontagem e conseqüente turnover dos complexos focais. A distribuição de SHP-2 em células migratórias foi avaliada na ausência ou presença de laminina-1 e na ausência ou presença de galectina-3 por 15 e 60 min. Observamos que existe um pool de Shp-2 bem distribuído pelo citoplasma, principalmente em células controle. Na presença de laminina-1 já observamos a pequena formação de ruffles de membrana e o recrutamento de SHP-2 para os complexos focais. Após 15 e 60 min observamos, na presença de galectina-3, aumento do número de ruffles de membrana e consequentemente aumento no recrutamento de Shp-2 para os complexos focais (Figura 27). 
FIGURA 27 A 
FIGURA 27 B 


\subsection{0 - CÉLULAS $\Sigma 12$ EM MIGRAÇÃO INTERNALIZAM GALECTINA-3}

Células $\Sigma 12$ foram incubadas na ausência ou na presença de galectina-3 e na ausência ou na presença de lactose por $1 \mathrm{~h}$ a $37^{\circ} \mathrm{C}$. Em seguida, a presença e localização de galectina-3 foi avaliada por microscopia de fluorescência. Os resultados mostraram que a galectina-3 foi internalizada pela células $\Sigma 12$ (Figura 28). O padrão de marcação sugere a presença de galectina-3 em vesículas endocíticas e no centro de organização dos microtúbulos (vide setas). Além disso, galectina-3 é encontrada no lamelipódio e filopódios de células migratórias (vide setas). A lactose inibiu a internalização de galectina-3 (inserto), sugerindo que a sua internalização seja dependente da interação com glicoconjugados presentes na superfície celular. 

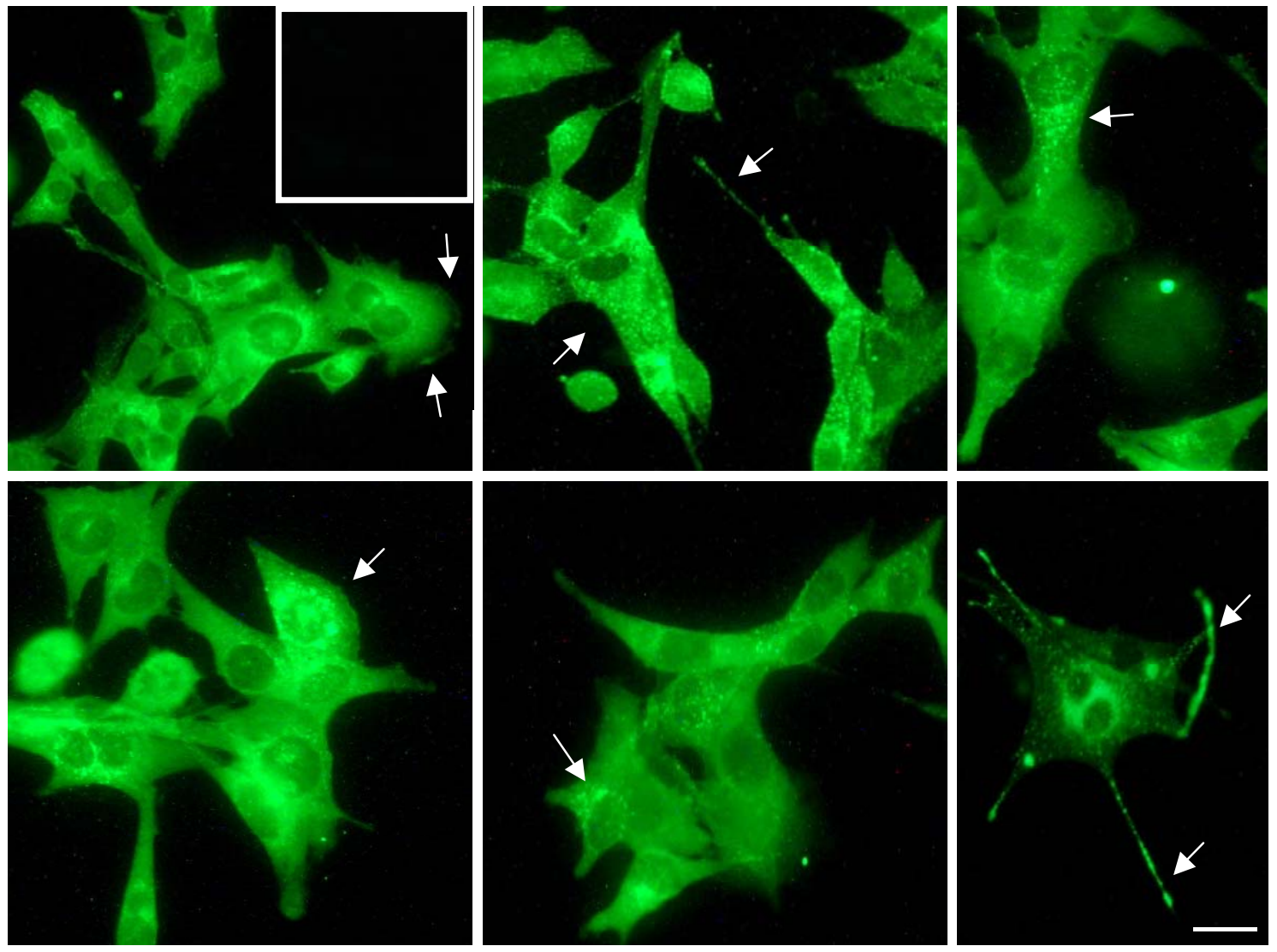

FIGURA 28. Galectina-3 é internalizada por células $\Sigma 12$ em migração. Células $\Sigma 12$ foram plaqueadas em lamínulas circulares por 48 horas. Após esse período, foi feito um risco para retirada de uma camada de células,e estas foram incubadas na ausência ou presença de $20 \mu \mathrm{g} / \mathrm{mL}$ de galectina-3 e também na ausência ou presença de $50 \mathrm{mM}$ de lactose por 1 hora a $37^{\circ} \mathrm{C}$. Em seguida estas células foram lavadas, fixadas, permeabilizadas e incubadas com anticorpo anti-galectina-3. As imagens foram visualizadas ao microscópio de fluorescência. As células $\Sigma 12$ internalizaram galectina-3, e que este processo foi inibido pela lactose (inserto). Nota-se a presença de galectina-3 em vesículas endocíticas,em lamelipódios e

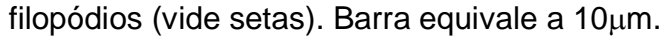




\subsection{1 - A ADIÇÃO DE GALECTINA-3 EXÓGENA EM CÉLULAS NÃO} ADERENTES NÃO INDUZ A INTERNALIZAÇÃO DE $\beta 1$ INTEGRINA

Para avaliar se a adição de galectina-3 exógena induz a internalização de $\beta 1$ integrina, as células $\Sigma 12$ foram tripsinizadas, lavadas e incubadas com galectina-3 nas concentrações de 20 e $40 \mu \mathrm{g} / \mathrm{mL}$ em meio DMEM sem soro em solução por $1 \mathrm{~h}$ a $37^{\circ} \mathrm{C}$. Os histogramas mostram que a adição de galectina-3 não alterou o padrão de expressão de $\beta 1$ integrina na superfície das células $\Sigma 12$ em suspensão (Figura 29). 

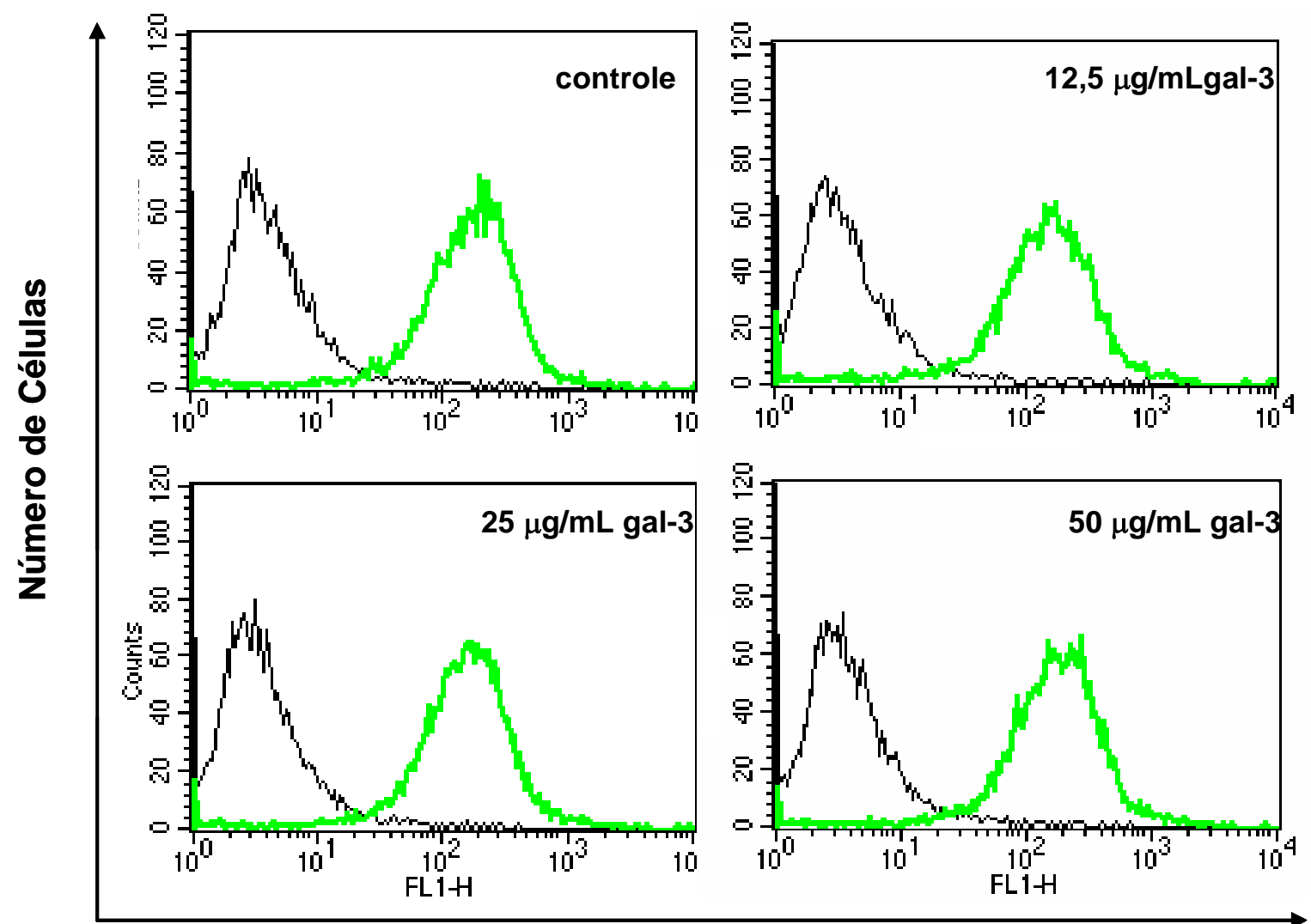

Intensidade de Fluorescência

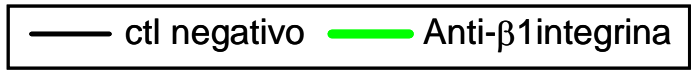

FIGURA 29. A adição de galectina-3 exógena em células não aderidas não induz a internalização de $\beta 1$ integrina. As células $\Sigma 12$ foram lavadas, tripsinizadas e em seguida incubadas com concentrações crescentes de galectina-3 recombinante por 1 hora a $37^{\circ} \mathrm{C}$. Em seguida, as células foram incubadas com anticorpo anti- $\beta 1$ integrina conjugado a FITC por 1 hora a $4^{\circ} \mathrm{C}$. A expressão de $\beta 1$ integrina foi avaliada através de citometria de fluxo. Os histogramas mostram que não houve diminuição da expressão de $\beta 1$ integrina na presença de galectina-3 exógena nas células em suspensão. 


\subsection{2 - A ADIÇÃO DE GALECTINA-3 EXÓGENA NÃO ATIVA PAK}

A formação de lamelipódios, complexos focais e de filopódios durante a migração celular é regulada pela família das pequenas GTPases Rac e Cdc42, respectivamente. Entre os números efetores identificados para Rac e cdc 42 está PAK. Em resposta a fatores de crescimento e proteínas da matriz extracelular, Rac ou cdc 42 são ativados, se ligam a PAK, que se autofosforila e é recrutado para os complexos focais e para os ruffles de membrana ${ }^{167}$.

Com o objetivo de avaliar a via de sinalização modulada por galectina-3 em fibroblastos migratórios em resposta a laminina-1, células $\Sigma 12$ foram incubadas na ausência ou presença de laminina-1 e na ausência ou presença de galectina-3 por 15 e 60 min. Os resultados indicam que na presença de galectina-3 PAK não é ativado e recrutado para os complexos focais , permanecendo distribuído no citoplasma (Figura 30). 
FIGURA 30 


\subsection{3 - WORTMANINA, UM INIBIDOR DE PI3-KINASE, BLOQUEIA O AUMENTO DE MIGRAÇÃO DE FIBROBLASTOS CAUSADO PELA ADIÇÃO DE GALECTINA-3}

Dados da literatura têm mostrado o envolvimento de PI3-kinase com o processo de migração celular ${ }^{168}$. Além disso, durante a formação de complexos focais, lamelipódios e filopódios, Rac e cdc42 ativam outras moléculas, entre elas PI3-kinase, a qual regula a reorganização do citoesqueleto ${ }^{169}$.

Com o objetivo de avaliar o envolvimento de PI3-kinase na migração de fibroblastos estimulados com galectina-3, células $\Sigma 12$ foram plaqueadas na ausência ou presença de wortmanina, que inibe diretamente a subunidade catalítica de PI3-kinase, por $24 \mathrm{~h}$. Os resultados mostraram que a wortmanina inibiu a migração depende de laminina-1 mais galectina-3, mas não a migração depende somente dependente de laminina-1 $(p<0,001)$ (Figura 31). 


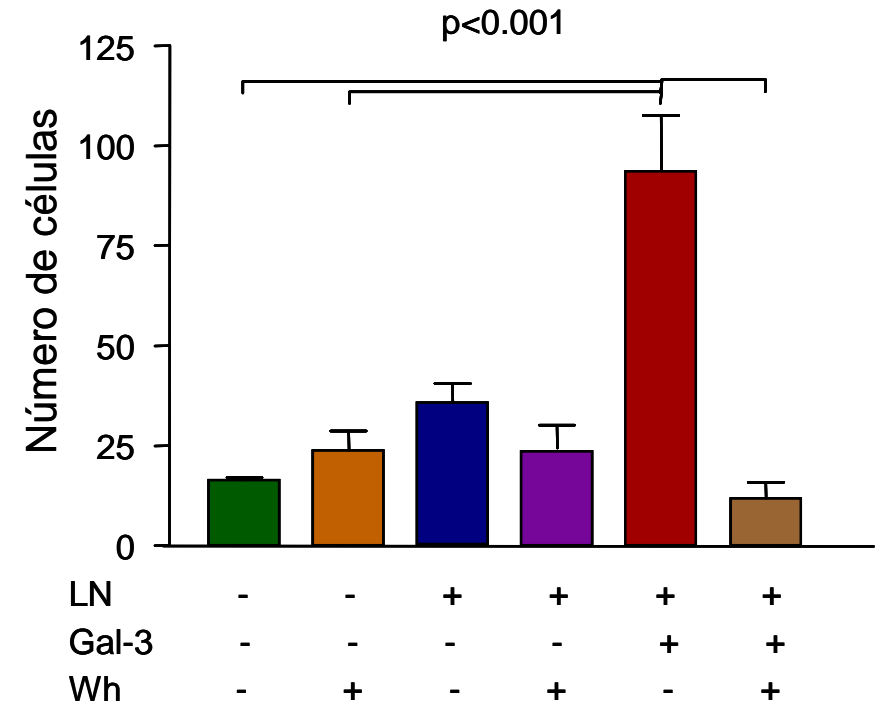

FIGURA 31. Wortmanina inibiu o efeito de galectina-3 sobre a migração das células $\Sigma 12$. As células $\Sigma 12$ foram plaqueadas em lamínulas circulares. Após 24 horas, estas células foram incubadas na ausência ou presença de $10 \mu \mathrm{g} / \mathrm{mL}$ de laminina-1, na ausência ou presença de $20 \mu \mathrm{g} / \mathrm{mL}$ de galectina-3 e também na ausência ou presença de $1 \mathrm{mM}$ de wortmanina por 24 horas. Em seguida, estas células foram fixadas, permeabilizadas e coradas com DAPI. A quantificação das células migratórias foi feita com o programa Eclipse Net. As análises foram feitas usando o método ANOVA, seguido do teste $t$ de Bonferroni para múltiplas comparações, usando-se o software Prism 3.0. A wortmanina inibiu o aumento de migração das células $\Sigma 12$ causado pela galectina-3, sugerindo que PI3K está na via de sinalização de galectina-3 $(p<0,001)$. 


\section{DISCUSSÃO}




\section{6 - DISCUSSÃO}

Lectinas são proteínas que reconhecem carboidratos. Estas proteínas têm sido largamente utilizadas na detecção e isolamento de glicoproteínas e caracterização de resíduos de carboidratos. Esta propriedade das lectinas é muito útil na identificação dos glicoconjugados presentes na superfície das células e em mudanças que ocorrem em processos como a transformação neoplásica ${ }^{12}$. As seqüências de carboidratos presentes na superfície celular têm papel importante na adesão e migração celular e no desenvolvimento de metástases ${ }^{22,170}$. A glicosilação aberrante de tumores, fenômeno que ocorre na transformação maligna e ao longo da progressão tumoral leva a alterações nas interações célula-célula e célula-matriz, pois interfere com a função de moléculas de adesão como caderinas e integrinas ${ }^{171-173}$. De fato, a N-glicosilação têm sido associada às alterações de comportamento observado nas células tumorais, como mudanças na adesividade as proteínas da matriz extracelular, aumento da migração e invasão celular e capacidade de crescimento independente de ancoragem.

Os dois tipos mais comuns de $N$-glicosilação aberrante observados em modelos tumorais são o aumento da sialilação terminal ${ }^{174}$ e 0 aparecimento de complexos tri- e tetra-antenares apresentando um resíduo de N-acetil-glucosamina ligada em configuração $\beta 1-6$ a manose ${ }^{18,170}$.

O aumento de expressão de polilactosaminas com ramificações do tipo $\beta 1-6$ GlcNAc tem sido correlacionado com o aumento do potencial metastático de tumores experimentais de camundongos ${ }^{175}$. Além disso, 
evidências sugerem que essas alterações poderiam ser usadas como marcadores para progressão de tumores de mama e de cólon ${ }^{17,176}$.

A formação dessas estruturas com ramificação $\beta 1-6$ GlcNAc é iniciada pela enzima Mgat5, uma enzima localizada no trans-golgi. A expressão de Mgat5 está aumentada em fibroblastos e células epiteliais transfectadas com os oncogenes $v$-src e H-ras ${ }^{177}$. De fato, a transcrição do gene Mgat5 é positivamente regulada pela sinalização downstream a esses oncogenes, principalmente pela via Ras-Raf-Ets ${ }^{170,178}$. Outros trabalhos mostram que a transfecção de Mgat5 em células epiteliais levou a perda da inibição por contato, aumento da motilidade celular, transformação morfológica em cultura, formação de tumores em camundongos atímicos e aumento da metástase ${ }^{20,21}$. Adicionalmente, o crescimento tumoral e o aparecimento de metástase foram atenuados em animais nulizigotos para o gene Mgat5 transfectados com o oncogene PyMT ${ }^{19}$.

Os produtos do gene Mgat5 são reconhecidos pela lectina vegetal LPHA que tem alta afinidade por estruturas com ramificações em configuração $\beta 1-6$ GlcNAc ${ }^{25}$. Existem alguns trabalhos mostrando evidências da correlação entre a expressão de moléculas L-PHA positivas e a aquisição de um fenótipo mais metastático ${ }^{18,26}$. No entanto, não existe consenso em relação ao significado clínico do L-PHA no diagnóstico e prognóstico de tumores.

Segundo dados da literatura, a lectina vegetal L-PHA apresenta especificidade semelhante à galectina-3 ${ }^{159,17,15,114}$. A galectina-3 está aumentada em diversos tipos de tumor, podendo ser considerada uma 
molécula associada a tumor ${ }^{116,121}$. Em alguns casos, pode-se observar uma relação direta entre o aumento nos níveis de galectina-3 e a aquisição de um fenótipo mais agressivo. Além do aumento de galectina-3, é plausível imaginar que os seus ligantes também estejam alterados ao longo do processo de transformação maligna, já que para exercer seu papel biológico a galectina-3 deva estar interagindo com seu glicoconjugado cognato.

Neste trabalho desenvolvemos uma molécula híbrida, a Gal-3/FA, que possui a atividade de lectina e atividade enzimática de fosfatase alcalina, podendo, dessa maneira, ser usada em ensaios imunoenzimáticos. O gene da galectina-3 humano foi fusionado com o gene bacteriano da fosfatase alcalina. A eficiência da geração da quimera foi confirmada por sequenciamento. Através da análise por western blotting, observamos que em condições não redutoras a Gal-3/FA é expressa nas formas monoméricas e dimérica. Sabe-se que a galectina-3 possui a capacidade de se agregar formando dímeros e/ou oligômeros ${ }^{179}$. É provável que a presença da forma dimérica de Gal-3/FA seja devido à dimerização da galectina-3 que na ausência do ligante é depende da porção carboxiterminal da proteína ${ }^{87}$. A especificidade da Gal-3/FA foi analisada em ensaio de ligação direta e observamos que esta possui a mesma especificidade da galectina-3, mostrando que a fusão com a fosfatase alcalina não alterou o domínio de reconhecimento de carboidratos.

O uso da Gal-3/FA foi avaliado em ensaios de overlay. Observamos que nas células $\Sigma 12$, CCR2 e B16F10, a Gal-3/FA se ligou a proteínas com massas moleculares aparentes de aproximadamente 60, 90, 116, 160 e > 
250 kDa. Trabalhos anteriores mostraram a presença de proteínas com massas moleculares similares em extratos de células ce carcinoma de cólon 180. Neste trabalho, a proteína de 116 kDa correspondia a Lamp-1 e 2, sialoglicoproteínas presentes na superfície de vários tipos celulares e envolvidas em adesão. Células $\Sigma 12$ e CCR2 foram tratadas com deoximanojirimicina, inibidor da $\alpha$-manosidase I, levando ao acúmulo de estruturas do tipo $\operatorname{Man}_{7-9} \mathrm{GlcNAc}_{2}$ e impedindo a ação da GlcNAc-T I. O resultado mostra a diminuição da reatividade da Gal-3/FA, já que não houve adição de ramificações do tipo $\beta 1-6$ GlcNAc. O mesmo ocorreu com a reatividade da lectina vegetal L-PHA. Inversamente, observamos o aumento da reatividade da lectina GNA, a qual reconhece glicoproteínas contendo resíduos de alta-manose. Nota-se que as células CCR2, que são fibroblastos transfectados com o oncogene EJ-ras, apresentam maior reatividade a Gal3/FA. Esse resultado corrobora com os achados da literatura, pois células transformadas com o oncogene EJ-ras têm aumento da atividade da enzima Mgat5 ${ }^{177}$. Num segundo experimento, células B16F10 e células $\Sigma 12$ foram tratadas com swainsonina, inibidor da $\alpha$-manosidase II, impedindo a ação das GlcNAc-Ts, as quais iniciam a adição das ramificações. Como esperado, a reatividade a L-PHA após o tratamento com swainsonina foi parcialmente inibida. Em relação a Gal-3/FA, observamos que nas células B16F10 após o tratamento com swainsonina, apareceu uma banda de massa molecular aparente de aproximadamente $66 \mathrm{kDa}$. Também observamos em ambas as células tratadas com SW que a banda de $116 \mathrm{kDa}$ teve sua massa molecular aparente diminuída. O retardo observado na migração das proteínas é 
devido à inibição da adição das ramificações. O reconhecimento de algumas proteínas pela Gal-3/FA não foi alterado, indicando que a Gal3/FA também reconhece glicoproteínas independentemente do processo de $N$-glicosilação. Dados da literatura ${ }^{88}$ e a Tabela $\vee$ mostram que galectina-3 também se liga a glicoconjugados que apresentam outros resíduos de carboidratos, como fucose e ácido siálico, na sua estrutura. Isso ocorre devido à presença de alguns aminoácidos no CRD da galectina-3 ${ }^{181}$.

Em seguida, nós avaliamos se a sialilação de timócitos interferia no reconhecimento dos ligantes de galectina-3. A diferenciação dos timócitos é acompanhada de alterações na expressão de genes bem como do padrão de glicosilação de suas proteínas ${ }^{182,183}$. Ao longo da maturação, têm-se o aumento da expressão de sialiltransferases, que adicionam resíduos de ácido siálico ao dissacarídeo terminal Gal $\beta 1 \rightarrow 3 G$ alNAc ${ }^{184-186}$, que se liga a galectina-3. A lectina vegetal PNA reconhece esse dissacarídeo ${ }^{187-189}$, sendo útil na identificação e separação de timócitos imaturos (que se ligam a PNA) dos timócitos maturos (que não se ligam a PNA) ${ }^{190,191}$. Nós observamos que extratos de timócitos tratados com neuraminidase não apresentaram alteração no padrão de reconhecimento da Gal-3/FA, mostrando que a sialilação não interfere no reconhecimento dos ligantes de galectina-3. Existem pelo menos duas famílias de sialiltransferases expressas no timo e que modificam oligossacarídeos $N$-ligados, uma que adiciona resíduos de ácido siálico na configuração $\alpha 2 \rightarrow 3$ e outra em configuração $\alpha 2 \rightarrow 6$. A neuraminidase utilizada tem a capacidade de hidrolisar todas essas ligações, mostrando que todos os resíduos de ácido 
siálico foram retirados. De fato, a Tabela $\vee$ mostrou que a Gal-3/FA liga-se a estruturas contendo resíduos de ácido siálico, isto é, a sialilação não mascara sítios de ligação de galectina-3.

Com o objetivo de avaliar o uso da Gal-3/FA como ferramenta na criação de um método prognóstico e diagnóstico de tumores, a Gal-3/FA foi testada em lâminas de tissue-arrays, contendo vários tipos de tumores humanos e a sua contraparte normal. Os resultados mostraram a presença de ligantes de galectina-3 em tumores de mama, próstata e de pâncreas bem diferenciados, que ainda possuem estruturas acinares. Os ligantes estão localizados na superfície apical das células epiteliais e no lúmen, indicando a presença de polilactosaminas. Nos tumores menos diferenciados, observamos a diminuição dos ligantes de galectina-3 nas células epiteliais e o aparecimento de ligantes em estruturas relacionadas com o endotélio e em células inflamatórias. Resultados experimentais sugerem que a galectina-3 esteja relacionada com a angiogênese. A galectina-3 afeta a quimiotaxia e estimula a formação de tubos capilares de células endoteliais in vitro e participa da angiogênese in vivo ${ }^{147}$. Além disso, a interação de galectina-3 presente na superfície de células endoteliais com glicoproteínas expressas por pericitos e por células tumorais também está envolvida no processo de neovascularização. Galectina-3 se liga e se complexa na superfície de células endoteliais com a $\alpha 3 \beta 1$ integrina e com o NG2, um condrotim-sulfato proteoglicano presente nos pericitos, e este complexo, estimula a migração e morfogênese de células endoteliais ${ }^{192}$. Um dos ligantes reconhecidos pela Gal-3/FA poderia ser o NG2 ou outros 
glicoconjugados que poderiam estar participando do processo de angiogênese. No microambiente tumoral também se encontram células inflamatórias, como neutrófilos e macrófagos. Resultados experimentais indicam que a galectina-3 participa de processos inflamatórios ${ }^{161,193}$. A galectina-3 extracelular se liga a células inflamatórias e modula ou ativa diversas funções celulares: (1) age como agente quimioatraente para monócitos e macrófagos durante a inflamação, dessa maneira, recrutando células inflamatórias e células apresentadoras de antígenos para os sítios inflamatórios ${ }^{112}$ : (2) induz a produção pelos neutrófilos de ânion superóxido através da interação com os receptores CD66a e CD66b ${ }^{194}$; (3) medeia a adesão de neutrófilos ao endotélio, induzindo o seu extravasamento para o pulmão ${ }^{195}$. Esses dados indicam a importância da interação galectina-3ligante e a identificação desses ligantes. Nossos resultados mostram a presença de ligantes de galectina-3 no infiltrado inflamatório de carcinomas de mama e de gliomas. Galectina-3 também interage com glicoproteínas da matriz extracelular, como laminina ${ }^{163}$ e proteoglicanos, explicando a forte marcação encontrada no estroma.

Também avaliamos a presença de ligantes de galectina-3 no timo, já que a galectina-3 secretada pelas células epiteliais tímicas age como uma molécula de-adesiva, inibindo a interação entre os timócitos e o microambiente tímico e permitindo a migração dos timócitos maturos no e para fora do timo ${ }^{149}$

Como mencionado acima, a diferenciação das células $T$ e a sua migração do córtex para medula são acompanhadas de alterações na 
glicosilação de seus receptores de superfície. De fato, nossos resultados mostraram que os timócitos localizados no córtex, que são timócitos imaturos, são fortemente reconhecidos pela Gal-3/FA, enquanto a marcação na medula é bem fraca. Evidências recentes mostraram que os timócitos duplo positivos $\left(\mathrm{CD}^{+}, \mathrm{CD} 8^{+}\right)$, que são imaturos, são mais migratórios que os timócitos maturos (Silva-Monteiro e col., em preparação). Esses dados em conjunto, sugerem que a galectina-3 formaria um gradiente haptotático na medula do timo, estimulando os timócitos imaturos a migrarem pela medula e a se diferenciarem.

Analisamos o padrão de marcação de L-PHA e observamos que é bem diferente do padrão da Gal-3/FA. Estes resultados sugerem que o perfil de distribuição de ligantes de galectina-3 é de fato diferente daquele antecipado pela ligação com L-PHA. O desenvolvimento da sonda descrita neste trabalho abre a perspectiva de se estudar com maior rigor a distribuição de células que expressem os ligantes de galectina-3, identificados pela lectina animal propriamente dita.

Observamos que os ligantes de galectina-3 são encontrados nas células tumorais que apresentam um comportamento invasivo. O padrão de invasão de células de sarcoma sobre as fibras musculares caracteriza um padrão de migração disfuncional ${ }^{196}$. Como o principal elemento nãocolagenêico de membranas basais é laminina, passamos a avaliar o papel de galectina-3 na migração dependente desta molécula de matriz extracelular. 
Nós mostramos anteriormente que células de sarcoma que expressam galectina-3 são mais migratórias e menos adesivas em superfícies de laminina-1 do que as células que não expressam galectina-3 (Anexo I). Porém o mecanismo modulado pela galectina-3 no processo de migração dessas células não é conhecido.

Apesar da galectina-3 não possuir peptídeo sinal, a galectina-3 pode ser encontrada tanto na superfície celular como na matriz extracelular. Foi mostrado que a fetuína, uma glicoproteína sérica, é capaz de induzir a secreção de galectina-3. Uma vez no espaço extracelular a galectina-3 estaria modulando as interações célula-matriz, já que foi observada a rápida adesão e espraiamento das células de carcinoma de mama após a secreção de galectina- ${ }^{108}$.

No nosso sistema, nós acreditamos que a laminina-1 esteja estimulando a secreção de galectina-3, e dessa maneira, a galectina-3 presente no meio extracelular, estaria modulando positivamente a migração das células de sarcoma. Para avaliar essa hipótese nós mimetizamos essa situação, e observamos que as células dos sarcomas gal-3 -/- na presença de galectina-3 exógena e de laminina-1 são mais migratórias do que as células controle ou aquelas incubadas somente com laminina-1. Esse efeito foi inibível por lactose, mostrando o envolvimento do domínio de reconhecimento de carboidratos (CRD) da galectina-3.

A migração é um processo integrado que requer a adesão e deadesão das células da matriz extracelular. O processo de migração é acompanhado da polarização da célula migratória, que tem como 
conseqüência, a extensão da membrana, que forma estruturas chamadas lamelipódios e filopódios na frente de migração da célula. Quando as integrinas se ligam aos componentes da matriz, elas se aproximam no plano da membrana plasmática, formando clusters e se associado aos filamentos de actina do citoesqueleto. A reorganização dos filamentos de actina em fibras de estresse, por sua vez, estimula ainda mais a formação de clusters, aumentando, dessa maneira, a ligação das integrinas a matriz, num sistema de retroalimentação positiva. Como resultado, tem-se a formação de estruturas supramoleculares chamadas de complexos focais ${ }^{42,42}$. Complexos focais recém-formados exercem sobre as células intensa força propulsiva e são responsáveis pela migração celular. À medida que mais proteínas são recrutadas para a formação dessas placas de adesão e estas amadurecem, a tração necessária para a migração vai diminuindo. Dessa maneira, os complexos focais passam a ancorar as células à matriz extracelular e estas se tornam menos migratórias ${ }^{31}$. A migração depende de um processo de liberação das células de sua matriz (de-adesão). Embora haja dúvidas quanto à dinâmica de de-adesão, ou ainda, se ela é ativa ou passiva, um crescente número de proteínas têm sido funcionalmente identificadas como moléculas de de-adesão.

Aqui nós mostramos que a galectina-3 é encontrada nos complexos focais, onde ela pode estar modulando a interação célula-matriz. $\mathrm{Na}$ presença de lactose observamos diminuição da forma dimérica de galectina3, sugerindo que esta apresenta maior afinidade pelos seus ligantes. Observamos também o aumento e diminuição de FAK nos complexos focais 
de células tratadas com galectina-3. A diminuição de FAK nos complexos focais poderia ser devido à sua desfosforilação por Shp-2, desestabilização dos complexos focais e conseqüente redistribuição de FAK para o citoplasma dessas células. No entanto, para afirmar isto, precisamos avaliar o perfil de fosforilação de FAK nos complexos focais.

Para modular o processo de migração celular, a galectina-3 deve se ligar a receptores na superfície da celular e ativar vias de sinalização. Nós mostramos que a galectina-3 se liga a glicoconjugados presentes na superfície das células $\Sigma 12$. Como dito anteriormente, a galectina-3 age com uma molécula quimioatraente para monócitos e macrófagos. Portanto, a galectina-3 poderia estar se ligando a receptores de quimiocinas e ativando as integrinas através da sinalização inside-out. Existem trabalhos demonstrando que quimiocinas são capazes de ativar as integrinas ${ }^{197}$. A galectina-3 também poderia estar interagindo diretamente com a integrina, ativando a sua via de sinalização. De fato, existem trabalhos mostrando a interação entre galectina-3 e integrinas ${ }^{163,192,198}$. Aqui nós mostramos que a galectina-3 interage diretamente com a $\beta 1$ integrina, sugerindo uma via de sinalização outside-in para a modulação da função da integrina.

Ochieng e col. mostraram que a adição de galectina-3 exógena as células de carcinoma de mama, desencadeia a endocitose do receptor de superfície $\beta 1$ integrina e da própria galectina-3. Em concentrações moderadas de galectina-3 há reorganização dos microfilamentos de actina e aumento do espraiamento celular, enquanto que em concentrações mais elevadas, as células arredondam, perdendo, dessa maneira, o contato com a 
matriz extracelular e conseqüentemente desorganizando o seu citoesqueleto 199. A recirculação das integrinas é um fenômeno conhecido, que está envolvida em processos como adesão celular, espraiamento e motilidade celular. Sendo o receptor $\beta 1$ integrina um dos principais receptores que medeiam o processo de migração celular em superfícies de laminina-1, pode-se propor que a sua endocitose em baixas concentrações de galectina3 estaria diminuindo a "adesividade" das células com a matriz extracelular e dessa maneira, aumentando a capacidade migratória dessas células. No entanto, nós não observamos a internalização de $\beta 1$ integrina quando as células $\Sigma 12$ em suspensão foram tratadas com diferentes concentrações de galectina-3 por diferentes tempos. Vários fatores podem explicar esse resultado. Entre eles, o nível de expressão de galectina-3 na superfície das células ou a concentração e valência da galectina-3 presente no microambiente. A glicosilação dos ligantes de galectina-3 também pode determinar o papel que a galectina-3 exercerá. No entanto, nós observmaos a internalização de galectina-3 em células aderentes. A galectina-3 é secretada para o meio extracelular onde modula o processo de migração celular. Em seguida, a galctina-3 poderia estar interagindo com glicoproteínas presentes na superfície celular e ser internalizada. Resta-nos avaliar se ocorre internalização de $\beta 1$ integrina durante a migração das células $\Sigma 12$. Talvez a internalização de $\beta 1$ integrina esteja associada ao estado adesivo da célula, só ocorrendo durante a migração celular. 
Por outro lado, a galectina-3 ao se ligar a $\beta 1$ integrina poderia mudar a sua conformação, e, dessa maneira, alterar a sua interação com as proteínas que compõe os complexos focais.

As proteínas presentes nos complexos focais podem ser divididas de acordo com as suas funções: proteínas do citoesqueleto, como tensina, vinculina, paxilina, $\alpha$-actinina e talina; proteínas tirosino-quinases, como Src, e FAK, PYK2; serino/treonino-quinases, como PKC, ILK e PAK; tirosinofosfatases, como Shp-2 e outras enzimas como PI 3-quinase e calpaína II $36,38,42$. O recrutamento de tirosino-quinases para os complexos focais leva a sua ativação e conseqüente fosforilação de inúmeras proteínas. Resultados indicam que a fosforilação de tirosinas, entre elas FAK, desempenham papel importante na organização dos complexos focais, na dinâmica de sua organização ${ }^{37,200}$ e conseqüentemente na regulação da motilidade celular.

Nós avaliamos a dinâmica de organização dos complexos focais na presença de galectina-3. Os resultados mostraram que na presença de galectina-3, há diminuição de FAK fosforilado nos complexos focais e reorganização do citoesqueleto.

FAK é rapidamente recrutado para os complexos focais o que leva a sua autofosforilação e ativação ${ }^{29}$. A fosforilação do resíduo de Tyr397 está relacionada ao aumento da atividade catalítica de FAK e promove a ligação de Src. Src ativado fosforila FAK nos resíduos de Tyr861 e Tyr925, criando domínios SH3 e SH2, respectivamente, que são sítios de ligação para outras proteínas ${ }^{127}$. Existem evidências do papel de FAK na regulação da migração celular. Fibroblastos FAK -/- apresentam diminuição de espraiamento celular, 
são menos migratórias e apresentam aumento do número e do tamanho de placas de adesão focal ${ }^{61}$. Como os fibroblastos FAK -/- apresentam aumento e não diminuição da formação dos complexos focais, a sinalização mediada por FAK tem sido associada à desmontagem dos complexos focais, ou seja, a inibição da migração nas células FAK -/- é resultado da inibição do seu turnover ${ }^{61,127}$.

A diminuição de FAK fosforilado nos complexos focais das células na presença de galectina-3 exógena sugere que a galectina-3 esteja desestabilizando os complexos focais, ou seja, aumentando o turnover dos complexos focais. Isso explicaria porque células que expressam galectina-3 são mais migratórias. Na presença de galectina-3, os complexos focais não amadureceriam ou diminuiriam sua estabilidade e dessa maneira a capacidade migratória dessas células estaria aumentada.

Para que ocorra o turnover dos complexos focais e as células migrem, estas devem ter a capacidade de desfosforilar FAK, permitindo, dessa maneira, a redistribuição de FAK para outros sítios onde estejam se formando novos complexos focais. De fato, a fosforilação de tirosinoquinases, como FAK, é um processo dinâmico e reversível, onde o nível de fosforilação é resultado do balanço entre a atividade catalítica da quinase e da fosfatase. De acordo com isso, estão trabalhos mostrando que a inibição de fosfatases com ortovanadato inibiu o espraiamento e a migração celular 201. De fato, nós observamos que o ortovanadato inibiu o efeito de prómigratório de galectina-3 sobre as células $\Sigma 12$, pois estas apresentaram diminuição de extensões e de ruffles de membrana, caracterizando um 
fenótipo menos migratório. Esse resultado sugere o envolvimento de fosfatases na modulação da migração das células $\Sigma 12$ em resposta à galectina-3.

Fibroblastos nulizigotos para o gene da fosfatase SHP-2 apresentam espraiamento e capacidade migratória diminuída em fibronectina. Além disso, nessas células há aumento do número de placas de adesão focal e presença de F-actina condensada na periferia celular ${ }^{202}$. Este fenótipo também é observado nas células FAK -/-, sugerindo que Shp-2 e FAK trabalham juntos na controle da dinâmica dos complexos focais. De fato, foi mostrado que nas células Shp-2 -/- FAK está hiperfosforilado e que a desfosforilação de FAK é dependente de Shp-2, sugerindo que FAK seja substrato de Shp- ${ }^{66}$.

Na presença de galectina-3 nós observamos o aumento do recrutamento de Shp-2 para os complexos focais, sugerindo que a diminuição da fosforilação de FAK observada é devido à ação de Shp-2. Portanto, na presença de galectina-3, Shp-2 é recrutado para os complexos focais, onde desfosforila FAK, o qual é redistribuído para o citoplasma. Isso leva a desestabilização e turnover dos complexos focais e conseqüente aumento da capacidade migratória dessas células.

Por outro lado, outros estudos mostraram que o acúmulo de complexos focais imaturos nas células Shp-2 -/- é resultado do aumento dos níveis de fosforilação do resíduo de Tyr12 da $\alpha$-actinina, pois esta é substrato de FAK. A fosforilação de $\alpha$-actinina reduz a sua interação com os filamentos de actina, levando a desestabilização dos complexos focais e 
conseqüentemente não gerando a força de tração necessária para as células migrarem ${ }^{64,67}$.

Esses trabalhos em conjunto mostram que a expressão de FAK e de Shp-2 e a regulação temporal da atividade dessas proteínas, são fatores importantes no controle da dinâmica dos complexos focais.

Além de funcionar como uma proteína adaptadora e recrutar outras proteínas para os complexos focais, FAK também modula vias de sinalização que regulam a adesão, migração e reorganização do citoesqueleto. Entre essas vias estão às proteínas da família Rho, que são Rac, Cdc42 e Rho ${ }^{203}$. Em células migratórias, Rac é importante para a formação de novos complexos focais na frente de migração, regulando o turnover dessas adesões indiretamente através da inibição de Rho ou diretamente através da ativação de seus efetores ${ }^{204}$. Entre os efetores de Rac, está PAK, que é recrutado para os complexos focais após a sua fosforilação e ativação onde participa da regulação da desmontagem dos complexos focais ${ }^{58,205}$.

No entanto, não foi observado nas nossas células o recrutamento de PAK 1/2 fosforilada para os complexos focais na presença de galectina-3. Esse resultado também foi encontrado em outros trabalhos que mostram que mutantes de Rac e Cdc42 que não ligam se a PAK in vitro, continuam mantendo a capacidade de estimular a formação de lamelipódios e filopódios, sugerindo que PAK não esteja envolvido neste processo ${ }^{206,207}$

Além disso, existem estudos mostrando o envolvimento de outras vias de sinalização ativadas por Rac e Cdc42 que regulam a formação de 
lamelipódios e filopódios, entre elas a via de fosfoinositil 3-quinase (PI3K) 169. As evidências do envolvimento de PI3K vêem de trabalhos que mostram que a subunidade regulatória de PI3K, a subunidade p85, se liga às formas ativas de Rac e Cdc42 ${ }^{168,208}$. Células epiteliais mamárias transfectadas com as formas ativadas de Rac e Cdc42 apresentaram inibição da formação dos lamelipódios e diminuição da migração na presença de wortmanina e LY294002, sugerindo a participação da via de PI3K.

A adição de galectina-3 exógena estimula a migração de fibroblastos transformados, no entanto, na presença de wortmanina, esse efeito da galectina-3 foi abolido. Esse resultado sugere o envolvimento de PI3K na indução de migração pela galectina-3. No entanto, são necessários outros dados para confirmar a participação da via de PI3Kinase.

Como já foi dito, a galectina-3 se liga a laminina-1, uma glicoproteína rica em cadeias de polilactosaminas e as integrinas através dos seus resíduos tri- e tetra-antenares. A galectina-3 em solução é monomérica, porém quando se liga aos seus ligantes se polimeriza, podendo dessa maneira, formar uma ponte entre, por exemplo, a integrina e a laminina-1, modulando essa interação e mediando o ciclo de adesão/de-adesão/adesão observado no processo de migração.

Nós observamos a presença de galectina-3 no lamelipódio de células CCR2 (que expressam galectina-3) em migração (Anexo I). O recrutamento de galectina-3 para a membrana plasmática poderia facilitar a sua translocação para o espaço extracelular, onde a galectina-3 permaneceria associada com glicoproteínas presentes na superfície celular. Apesar da 
galectina-3 não possuir peptídio sinal, a galectina-3 é secretada para o meio extracelular através de um mecanismo não convencional ${ }^{106,107}$. A exposição das células a ligantes de galectina-3, como fetuína, induz a secreção de galectina-3 ${ }^{108}$. Nós observamos que a secreção de galectina-3 também ocorre na presença de laminina-1. Nós também observamos o aumento da capacidade migratória de células nulizigotas para o gene da galectina-3 na presença de galectina-3 exógena, o que sugere que a galectina-3 presente no espaço extracelular que esteja modulando positivamente o processo de migração celular.

Nós também mostramos a presença de galectina-3 nos complexos focais, onde a galectina-3 estaria interagindo com a $\beta 1$ integrina. Esses dados sugerem que a galectina-3 estaria modulando a função da integrina através da sinalização outside-in. A interação galectina-3- $\beta 1$ integrina alteraria a conformação da integrina, estimularia o recrutamento de Shp-2 para os complexos focais e a conseqüente desfosforilação de FAK. A diminuição de FAK fosforilado no lamelipódio de células em processo de migração levaria ao turnover dos complexos focais e a sua subseqüente desestabilização. Conseqüentemente os complexos focais não amadureceriam ou diminuiriam sua estabilidade e dessa maneira a capacidade migratória dessas células estaria aumentada.

Nossos dados em conjunto mostram que a galectina-3 age como uma molécula de de-adesão, modulando positivamente o processo de migração celular e podendo ser classificada como uma proteína matricelular, isto é, a galectina-3 encontra-se na matriz extracelular sem fazer parte de sua 
estrutura. Proteínas matricelulares agiriam como moduladores da interação célula-matriz ${ }^{209}$. Exemplos incluem SPARC 210,211, tenascina-C 212,213, trombospondina ${ }^{214,215}$ e galectina-8 ${ }^{148,216}$. Aqui damos evidências de que galectina-3 seja mais um membro desta família de potenciais moléculas associadas à progressão tumoral. 
CONCLUSÕES 


\section{7 - CONCLUSÕES}

7.1 - A geração da proteína quimérica Gal-3/FA permitiu a análise da expressão e distribuição dos ligantes de galectina-3 em tecidos humanos e murinos. Em ensaios de overlay identificamos que $\beta 1$ integrina, de fato, é ligante de galectina-3;

7.2 - A galectina-3 extracelular age como uma molécula pró-migratória, de maneira carboidrato-dependente, recrutando SHP-2 para os complexos focais, o que leva a desfosforilação de FAK e turnover dos complexos focais. Esse efeito não é devido à ativação e fosforilação de PAK 1/2, porém se observou envolvimento da via de sinalização de PI3-kinase na atividade prómigratória de galectina-3. 
REFERÊNCIAS BIBLIOGRÁFICAS 


\section{8 - REFERÊNCIAS BIBLIOGRÁFICAS}

1. Hanahan, D. and Weinberg, R. A. Th7e hallmarks of cancer. Cell, 100: 57-70, 2000.

2. Keely, P., Parise, L., and Juliano, R. Integrins and GTPases in tumour cell growth, motility and invasion. Trends Cell Biol., 8: 101106, 1998.

3. Classon, M. and Settleman, J. Emerging concepts in tumor progression and therapy. Semin.Cancer Biol., 10: 393-397, 2000.

4. Hakomori, S. Aberrant glycosylation in tumors and tumor-associated carbohydrate antigens. Adv.Cancer Res., 52: 257-331, 1989.

5. Hakomori, S. Glycosylation defining cancer malignancy: New wine in an old bottle. Proc.Natl.Acad.Sci.U.S.A, 99: 10231-10233, 2002.

6. Dennis, J. W., Granovsky, M., and Warren, C. E. Glycoprotein glycosylation and cancer progression. Biochim.Biophys.Acta, 1473: 21-34, 1999.

7. Asada, M., Furukawa, K., Segawa, K., Endo, T., and Kobata, A. Increased expression of highly branched N-glycans at cell surface is correlated with the malignant phenotypes of mouse tumor cells. Cancer Res., 57: 1073-1080, 1997. 
8. Dennis, J. W., Pawling, J., Cheung, P., Partridge, E., and Demetriou, M. UDP-N-acetylglucosamine:alpha-6-D-mannoside beta1,6 Nacetylglucosaminyltransferase $\mathrm{V}$ (Mgat5) deficient mice. Biochim.Biophys.Acta, 1573: 414-422, 2002.

9. Yoshimura, M., Ihara, Y., Matsuzawa, Y., and Taniguchi, N. Aberrant glycosylation of E-cadherin enhances cell-cell binding to suppress metastasis. J.Biol.Chem., 271: 13811-13815, 1996.

10. Fuster, M. M. and Esko, J. D. The sweet and sour of cancer: glycans as novel therapeutic targets. Nat.Rev.Cancer, 5: 526-542, 2005.

11. Raedler, A. and Schreiber, S. Analysis of differentiation and transformation of cells by lectins. Crit Rev.Clin.Lab Sci., 26: 153-193, 1988.

12. Gabius, H. J. Animal lectins. European Journal of Biochemistry (243), 543-576. 1996.

13. Varki, A., Cummings, R., Esko J., Freeze H., Hart, G., and Marth, J. Essentials of Glycobiology, $1^{\mathrm{a}}$ ed. Cold Spring Harbor Laboratory Press, 1999.

14. Feizi, T. Carbohydrate antigens in human cancer. Cancer Surv., 4: 245-269, 1985.

15. Dennis, J. W., Laferte, S., Waghorne, C., Breitman, M. L., and Kerbel, R. S. $\beta 1-6$ branching of Asn-linked oligosaccharides is directly associated with metastasis. Science, 236: 582-585, 1987. 
16. Dennis, J. W. and Laferte, S. Oncodevelopmental expression of-GlcNAc beta 1-6Man alpha 1-6Man beta 1- -branched asparaginelinked oligosaccharides in murine tissues and human breast carcinomas. Cancer Res., 49: 945-950, 1989.

17. Fernandes, B., Sagman, U., Auger, M., Demetrio, M., and Dennis, J. W. $\beta 1-6$ branched oligosaccharides as a marker of tumor progression in human breast and colon neoplasia. Cancer Res., 51: 718-723, 1991.

18. Handerson, T. and Pawelek, J. M. Beta1,6-branched oligosaccharides and coarse vesicles: a common, pervasive phenotype in melanoma and other human cancers. Cancer Res., 63: 5363-5369, 2003.

19. Granovsky, M., Fata, J., Pawling, J., Muller, W. J., Khokha, R., and Dennis, J. W. Suppression of tumor growth and metastasis in Mgat5deficient mice. Nat.Med., 6: 306-312, 2000.

20. Demetriou, M., Nabi, I. R., Coppolino, M., Dedhar, S., and Dennis, J. W. Reduced contact-inhibition and substratum adhesion in epithelial cells expressing GlcNAc-transferase V. J.Cell Biol., 130: 383-392, 1995.

21. Seberger, P. J. and Chaney, W. G. Control of metastasis by Asnlinked, beta1-6 branched oligosaccharides in mouse mammary cancer cells. Glycobiol., 9: 235-241, 1999. 
22. Guo, H. B., Lee, I., Kamar, M., Akiyama, S. K., and Pierce, M. Aberrant $\mathrm{N}$-glycosylation of beta1 integrin causes reduced alpha5beta1 integrin clustering and stimulates cell migration. Cancer Res., 62: 6837-6845, 2002.

23. Goss, P. E., Reid, C. L., Bailey, D., and Dennis, J. W. Phase IB clinical trial of the oligosaccharide processing inhibitor swainsonine in patients with advanced malignancies. Clin.Cancer Res., 3: 10771086, 1997.

24. Fiaux, H., Popowycz, F., Favre, S., Schutz, C., Vogel, P., GerberLemaire, S., and Juillerat-Jeanneret, L. Functionalized pyrrolidines inhibit alpha-mannosidase activity and growth of human glioblastoma and melanoma cells. J.Med.Chem., 48: 4237-4246, 2005.

25. Cummings, R. D. and Kornfeld, S. Characterization of the structural determinants required for the high affinity interaction of asparaginelinked oligosaccharides with immobilized Phaseolus vulgaris leukoagglutinating and erythroagglutinating lectins. J.Biol.Chem., 257: 11230-11234, 1982.

26. Mori, S., Nose, M., Morikawa, H., Sato, A., Saito, T., Song, S. T., Tanda, N., and Teshima, T. A novel evaluation system of metastatic potential of oral squamous cell carcinoma according to the histopathological and histochemical grading. Oral Oncol., 34: 549$557,1998$. 
27. Brakebusch, C. and Fassler, R. The integrin-actin connection, an eternal love affair. EMBO J., 22: 2324-2333, 2003.

28. DeMali, K. A., Wennerberg, K., and Burridge, K. Integrin signaling to the actin cytoskeleton. Curr.Opin.Cell Biol., 15: 572-582, 2003.

29. Lauffenburger, D. A. and Horwitz, A. F. Cell migration: a physically integrated molecular process. Cell, 84: 359-369, 1996.

30. Condeelis, J. S., Wyckoff, J. B., Bailly, M., Pestell, R., Lawrence, D., Backer, J., and Segall, J. E. Lamellipodia in invasion. Semin.Cancer Biol, 11: 119-128, 2001.

31. Beningo, K. A., Dembo, M., Kaverina, I., Small, J. V., and Wang, Y. L. Nascent focal adhesions are responsible for the generation of strong propulsive forces in migrating fibroblasts. J.Cell Biol., 153: 881-888, 2001.

32. Kassis, J., Lauffenburger, D. A., Turner, T., and Wells, A. Tumor invasion as dysregulated cell motility. Semin.Cancer Biol., 11: 105117, 2001.

33. Regen, C. M. and Horwitz, A. F. Dynamics of beta 1 integrinmediated adhesive contacts in motile fibroblasts. J.Cell Biol., 119: 1347-1359, 1992. 
34. Pierini, L. M., Lawson, M. A., Eddy, R. J., Hendey, B., and Maxfield, F. R. Oriented endocytic recycling of alpha5beta1 in motile neutrophils. Blood, 95: 2471-2480, 2000.

35. Craig, S. W. and Johnson, R. P. Assembly of focal adhesions: progress, paradigms, and portents. Curr Op Cell Biol 8, 74-85. 1996.

36. Zamir, E. and Geiger, B. Molecular complexity and dynamics of cellmatrix adhesions. J.Cell Sci., 114: 3583-3590, 2001.

37. Schoenwaelder, S. M. and Burridge, K. Bidirectional signaling between the cytoskeleton and integrins. Curr.Opin.Cell Biol., 11: 274-286, 1999.

38. Zamir, E. and Geiger, B. Components of cell-matrix adhesions. J.Cell Sci., 114: 3577-3579, 2001.

39. Nobes, C. D. and Hall, A. Rho, Rac, and Cdc42 GTPases regulate the assembly of multimolecular focal complexes associated with actin stress fibers, lamellipodia, and filopodia. Cell. 81, 53-62. 1995.

40. Webb, D. J., Parsons, J. T., and Horwitz, A. F. Adhesion assembly, disassembly and turnover in migrating cells -- over and over and over again. Nat.Cell Biol., 4: E97-100, 2002.

41. Lee, J. and Jacobson, K. The composition and dynamics of cellsubstratum adhesions in locomoting fish keratocytes. J.Cell Sci., 110 (Pt 22): 2833-2844, 1997. 
42. Petit, V. and Thiery, J. P. Focal adhesions: structure and dynamics. Biol.Cell, 92: 477-494, 2000.

43. Chrzanowska-Wodnicka, M. and Burridge, K. Rho-stimulated contractility drives the formation of stress fibers and focal adhesions. J.Cell Biol., 133: 1403-1415, 1996.

44. Sastry, S. K. and Burridge, K. Focal adhesions: a nexus for intracellular signaling and cytoskeletal dynamics. Exp.Cell Res., 261: 25-36, 2000.

45. Miyamoto, S., Akiyama, S. K., and Yamada, K. M. Synergistic roles for receptor occupancy and aggregation in integrin transmembrane function. Science, 267: 883-885, 1995.

46. Schlaepfer, D. D., Mitra, S. K., and Ilic, D. Control of motile and invasive cell phenotypes by focal adhesion kinase. Biochim.Biophys.Acta, 1692: 77-102, 2004.

47. Schaller, M. D. Biochemical signals and biological responses elicited by the focal adhesion kinase. Biochim.Biophys.Acta, 1540: 1-21, 2001.

48. Sieg, D. J., Hauck, C. R., Ilic, D., Klingbeil, C. K., Schaefer, E., Damsky, C. H., and Schlaepfer, D. D. FAK integrates growth-factor and integrin signals to promote cell migration. Nat.Cell Biol., 2: 249256, 2000. 
49. Turner, C. E. Paxillin and focal adhesion signalling. Nat.Cell Biol., 2: E231-E236, 2000.

50. Chodniewicz, D. and Klemke, R. L. Regulation of integrin-mediated cellular responses through assembly of a CAS/Crk scaffold. Biochim.Biophys.Acta, 1692: 63-76, 2004.

51. Cho, S. Y. and Klemke, R. L. Purification of pseudopodia from polarized cells reveals redistribution and activation of Rac through assembly of a CAS/Crk scaffold. J.Cell Biol., 156: 725-736, 2002.

52. Brabek, J., Constancio, S. S., Shin, N. Y., Pozzi, A., Weaver, A. M., and Hanks, S. K. CAS promotes invasiveness of Src-transformed cells. Oncogene, 23: 7406-7415, 2004.

53. Hagel, M., George, E. L., Kim, A., Tamimi, R., Opitz, S. L., Turner, C. E., Imamoto, A., and Thomas, S. M. The adaptor protein paxillin is essential for normal development in the mouse and is a critical transducer of fibronectin signaling. Mol.Cell Biol., 22: 901-915, 2002.

54. Honda, H., Oda, H., Nakamoto, T., Honda, Z., Sakai, R., Suzuki, T., Saito, T., Nakamura, K., Nakao, K., Ishikawa, T., Katsuki, M., Yazaki, Y., and Hirai, H. Cardiovascular anomaly, impaired actin bundling and resistance to Src-induced transformation in mice lacking p130Cas. Nat.Genet., 19: 361-365, 1998.

55. Laukaitis, C. M., Webb, D. J., Donais, K., and Horwitz, A. F. Differential dynamics of alpha 5 integrin, paxillin, and alpha-actinin 
during formation and disassembly of adhesions in migrating cells. J.Cell Biol., 153: 1427-1440, 2001.

56. Rottner, K., Hall, A., and Small, J. V. Interplay between Rac and Rho in the control of substrate contact dynamics. Curr.Biol., 9: 640-648, 1999.

57. Zhao, Z. S., Manser, E., Chen, X. Q., Chong, C., Leung, T., and Lim, L. A conserved negative regulatory region in alphaPAK: inhibition of PAK kinases reveals their morphological roles downstream of Cdc42 and Rac1. Mol.Cell Biol., 18: 2153-2163, 1998.

58. Manser, E., Huang, H. Y., Loo, T. H., Chen, X. Q., Dong, J. M., Leung, T., and Lim, L. Expression of constitutively active alpha-PAK reveals effects of the kinase on actin and focal complexes. Mol.Cell Biol., 17: 1129-1143, 1997.

59. Dharmawardhane, S., Sanders, L. C., Martin, S. S., Daniels, R. H., and Bokoch, G. M. Localization of p21-activated kinase 1 (PAK1) to pinocytic vesicles and cortical actin structures in stimulated cells. J.Cell Biol., 138: 1265-1278, 1997.

60. Sells, M. A., Boyd, J. T., and Chernoff, J. p21-activated kinase 1 (Pak1) regulates cell motility in mammalian fibroblasts. J.Cell Biol., 145: 837-849, 1999.

61. Ilic, D., Furuta, Y., Kanazawa, S., Takeda, N., Sobue, K., Nakatsuji, N., Nomura, S., Fujimoto, J., Okada, M., and Yamamoto, T. 
Reduced cell motility and enhanced focal adhesion contact formation in cells from FAK-deficient mice. Nature, 377: 539-544, 1995.

62. Sieg, D. J., Hauck, C. R., and Schlaepfer, D. D. Required role of focal adhesion kinase (FAK) for integrin-stimulated cell migration. J.Cell Sci., 112 ( Pt 16): 2677-2691, 1999.

63. Owen, J. D., Ruest, P. J., Fry, D. W., and Hanks, S. K. Induced focal adhesion kinase (FAK) expression in FAK-null cells enhances cell spreading and migration requiring both auto- and activation loop phosphorylation sites and inhibits adhesion-dependent tyrosine phosphorylation of Pyk2. Mol.Cell Biol., 19: 4806-4818, 1999.

64. Izaguirre, G., Aguirre, L., Hu, Y. P., Lee, H. Y., Schlaepfer, D. D., Aneskievich, B. J., and Haimovich, B. The cytoskeletal/non-muscle isoform of alpha-actinin is phosphorylated on its actin-binding domain by the focal adhesion kinase. J.Biol.Chem., 276: 2867628685, 2001.

65. Yu, D. H., Qu, C. K., Henegariu, O., Lu, X., and Feng, G. S. Proteintyrosine phosphatase Shp-2 regulates cell spreading, migration, and focal adhesion. J.Biol.Chem., 273: 21125-21131, 1998.

66. Manes, S., Mira, E., Gomez-Mouton, C., Zhao, Z. J., Lacalle, R. A., and Martinez, A. Concerted activity of tyrosine phosphatase SHP-2 and focal adhesion kinase in regulation of cell motility. Mol.Cell Biol., 19: 3125-3135, 1999. 
67. von Wichert, G., Haimovich, B., Feng, G. S., and Sheetz, M. P. Force-dependent integrin-cytoskeleton linkage formation requires downregulation of focal complex dynamics by Shp2. EMBO J., 22: 5023-5035, 2003.

68. Webb, D. J., Donais, K., Whitmore, L. A., Thomas, S. M., Turner, C. E., Parsons, J. T., and Horwitz, A. F. FAK-Src signalling through paxillin, ERK and MLCK regulates adhesion disassembly. Nat.Cell Biol., 6: 154-161, 2004.

69. Barondes, S. H., Cooper, D. N., Gitt, M. A., and Leffler, H. Galectins: structure and function of a large family of animal lectins. J.Biol.Chem., 269: 20807-20810, 1994.

70. Kasai, K. I. and Hirabayashi, J. Galectins: a family of animal lectins that decipher glycocodes. J.Biochem., 119: 1-8, 1996.

71. Barondes, S. H., Castronovo, V., Cooper, D. N. W., Cummings, R. D., Drickamer, K., Feizi, T., Gitt, M. A., Hirabayashi, J., Hughes, R. C., Kasai, K., Leffler, H., Liu, F.-T., Lotan, R., Mercurio, A. M., Monsigny, M., Pillai, S., Poirier, F., Raz, A., Rigby, P. W. J., Rini, J. M., and Wang, J. L. Galectins: a family of animal beta-galactosidebinding lectins. Cell. 76(597), 598. 1994.

72. Cooper, D. N. and Barondes, S. H. God must love galectins; he made so many of them. Glycobiol., 9: 979-984, 1999. 
73. Yang, R. Y., Hsu, D. K., Yu, L., Ni, J., and Liu, F. T. Cell cycle regulation by galectin-12, a new member of the galectin superfamily. J Biol Chem, 276: 20252-20260, 2001.

74. Gray, C. A., Dunlap, K. A., Burghardt, R. C., and Spencer, T. E. Galectin-15 in ovine uteroplacental tissues. Reproduction, 130: 231240, 2005.

75. Harrison, L. Soluble beta-galactoside-binding lectins in vertebrates. Lectin Reviews 1, 17-39. 1991.

76. Hirabayashi, Jun and Kasai, Ken-ichi. The family of metazoan metalindependent beta-galactoside-binding lectins: structure, function and molecular evolution. Glycobiology 3(4), 297-304. 1993.

Ref Type: Journal (Full)

77. Woo, H-J., Shaw, L. M., Messier, J. M., and Mercurio, A. M. The major non-integrin laminin binding protein of macrophages is identical to carbohydrate binding protein 35 (Mac-2). Journal of Biological Chemistry 265, 7097-7099. 1990.

78. Sato, S. and Hughes, R. C. Regulation of secretion and surface expression of Mac-2, a galactoside-binding protein of macrophages. The Journal of Biological Chemistry 269(6), 4424-4460. 1993.

79. Agrwal, N., Wang, J. L., and Voss, P. G. Carbohydrate-binding protein 35. Levels of transcription and mRNA accumulation in quiescent and proliferating cells. J.Biol.Chem., 264: 17236-17242, 1989. 
80. Kadrofske, M. M., Openo, K. P., and Wang, J. L. The human LGALS3 (galectin-3) gene: determination of the gene structure and functional characterization of the promoter. Arch.Biochem.Biophys., 349: 7-20, 1998.

81. Ruebel, K. H., Jin, L., Qian, X., Scheithauer, B. W., Kovacs, K., Nakamura, N., Zhang, H., Raz, A., and Lloyd, R. V. Effects of DNA methylation on galectin-3 expression in pituitary tumors. Cancer Res., 65: 1136-1140, 2005.

82. Hsu, D. K., Hammes, S. R., Kuwabara, I., Greene, W. C., and Liu, F.-T. Human $T$ Lymphotropic Virus-I infection of human $T$ lymphocytes induces expression of the beta-galactoside-binding lectin, galectin-3. Am.J.Pathol., 148: 1661-1670, 1996.

83. Schroder, H. C., Ushijima, H., Theis, C., Seve, A. P., Hubert, J., and Muller, W. E. Expression of nuclear lectin carbohydrate-binding protein 35 in human immunodeficiency virus type 1-infected Molt-3 cells. J.Acquir.Immune.Defic.Syndr.Hum.Retrovirol., 9: 340-348, 1995.

84. Gaudin, J. C., Arar, C., Monsigny, M., and Legrand, A. Modulation of the expression of the rabbit galectin-3 gene by p53 and c- Ha-ras proteins and PMA. Glycobiol., 7: 1089-1098, 1997.

85. Kim, K., Mayer, E. P., and Nachtigal, M. Galectin-3 expression in macrophages is signaled by Ras/MAP kinase pathway and up- 
regulated by modified lipoproteins. Biochim.Biophys.Acta, 1641: 1323, 2003.

86. Gong, H. C., Honjo, Y., Nangia-Makker, P., Hogan, V., Mazurak, N., Bresalier, R. S., and Raz, A. The NH2 terminus of galectin-3 governs cellular compartmentalization and functions in cancer cells. Cancer Res., 59: 6239-6245, 1999.

87. Yang, R. Y., Hill, P. N., Hsu, D. K., and Liu, F. T. Role of the carboxyl-terminal lectin domain in self-association of galectin-3. Biochem., 37: 4086-4092, 1998.

88. Ochieng, J., Furtak, V., and Lukyanov, P. Extracellular functions of galectin-3. Glycoconj.J., 19: 527-535, 2004.

89. Barboni, E. A., Bawumia, S., and Hughes, R. C. Kinetic measurements of binding of galectin 3 to a laminin substratum. Glycoconj.J., 16: 365-373, 1999.

90. Ochieng, J., Platt, D., Tait, L., Hogan, V., Raz, T., Carmi, P., and Raz, A. Structure-function relationship of a recombinant human galactoside-binding protein. Biochemistry 32, 4455-4460. 1993.

91. Brewer, C. F., Miceli, M. C., and Baum, L. G. Clusters, bundles, arrays and lattices: novel mechanisms for lectin- saccharidemediated cellular interactions. Curr.Opin.Struct.Biol., 12: 616-623, 2002. 
92. Lin, H. M., Moon, B. K., Yu, F., and Kim, H. R. Galectin-3 mediates genistein-induced $G(2) / M$ arrest and inhibits apoptosis. Carcinogenesis, 21: 1941-1945, 2000.

93. Inohara, H., Akahani, S., and Raz, A. Galectin-3 stimulates cell proliferation. Exp.Cell Res., 245: 294-302, 1998.

94. Dagher, S. F., Wang, J. L., and Patterson, R. J. Identification of galectin-3 as a factor in pre-mRNA splicing. Proc.Natl.Acad.Sci.U.S A, 92: 1213-1217, 1995.

95. Shimura, T., Takenaka, Y., Tsutsumi, S., Hogan, V., Kikuchi, A., and Raz, A. Galectin-3, a novel binding partner of beta-catenin. Cancer Res., 64: 6363-6367, 2004.

96. Yu, F., Finley, R. L., Jr., Raz, A., and Kim, H. R. Galectin-3 translocates to the perinuclear membranes and inhibits cytochrome c release from the mitochondria. A role for synexin in galectin-3 translocation. J.Biol.Chem., 277: 15819-15827, 2002.

97. Elad-Sfadia, G., Haklai, R., Balan, E., and Kloog, Y. Galectin-3 augments K-Ras activation and triggers a Ras signal that attenuates ERK but not phosphoinositide 3-kinase activity. J.Biol.Chem., 279: 34922-34930, 2004.

98. Hubert, Michelle, Wang, Sung-Yuan, Wang, John L., Sève, AnniePierre, and Hubert, Jean. Intranuclear distribution of galectin-3 in mouse 3 T3 fibroblasts: comparative analyses by 
immunofluorescence and immunoelectron microscopy. Experimental Cell Research (220), 397-406. 1995.

99. Frigeri, L. G., Zuberi, R. I., and Liu, F. T. Epsilon BP, a betagalactoside-binding animal lectin, recognizes IgE receptor (Fc epsilon RI) and activates mast cells. Biochem., 32: 7644-7649, 1993.

100. Zuberi, R. I., Frigeri, L. G., and Liu, F. T. Activation of rat basophilic leukemia cells by epsilon BP, an IgE-binding endogenous lectin. Cell Immunol., 156: 1-12, 1994.

101. Mengwasser, J., Liu, F. T., and Sleeman, J. P. Galectin-3 is strongly up-regulated in nonapoptosing mammary epithelial cells during rat mammary gland involution. Glycobiol., 12: 129-134, 2002.

102. Sato, S. and Hughes, R. C. Regulation of secretion and surface expression of Mac-2, a galactoside-binding protein of macrophages. J.Biol.Chem., 269: 4424-4430, 1994.

103. Cameron, A. A., Dougherty, P. M., Garrison, C. J., Willis, W. D., and Carlton, S. M. The endogenous lectin RL-29 is transynaptically induced in dorsal horn neurons following peripheral neuropathy in the rat. Brain Res., 620: 64-71, 1993.

104. Huflejt, M. E., Turck, C. W., Lindstedt, R., Barondes, S. H., and Leffler, H. L-29, a soluble lactose-binding lectin, is phosphorylated on serine 6 and serine 12 in vivo and by casein kinase I. J.Biol.Chem., 268: 26712-26718, 1993. 
105. Mazurek, N., Conklin, J., Byrd, J. C., Raz, A., and Bresalier, R. S. Phosphorylation of the beta-galactoside-binding protein galectin-3 modulates binding to its ligands. J.Biol.Chem., 275: 36311-36315, 2000.

106. Sato, S., Burdett, I., and Hughes, R. C. Secretion of the baby hamster kidney 30-kDa galactose-binding lectin from polarized and nonpolarized cells: a pathway independent of the endoplasmic reticulum-Golgi complex. Exp.Cell Res., 207: 8-18, 1993.

107. Lindstedt, R., Apodaca, G., Barondes, S. H., Mostov, K. E., and Leffler, H. Apical secretion of a cytosolic protein by Madin-Darby canine kidney cells. Evidence for polarized release of an endogenous lectin by a nonclassical secretory pathway. J.Biol.Chem., 268: 11750-11757, 1993.

108. Zhu, W. Q. and Ochieng, J. Rapid release of intracellular galectin-3 from breast carcinoma cells by fetuin. Cancer Res., 61: 1869-1873, 2001.

109. Cortegano, I., del, P., V, Cardaba, B., de Andres, B., Gallardo, S., del Amo, A., Arrieta, I., Jurado, A., Palomino, P., Liu, F. T., and Lahoz, C. Galectin-3 down-regulates IL-5 gene expression on different cell types. J Immunol., 161: 385-389, 1998. 
110. Yamaoka, A., Kuwabara, I., Frigeri, L. G., and Liu, F. T. A human lectin, galectin-3 (epsilon bp/Mac-2), stimulates superoxide production by neutrophils. J.Immunol., 154: 3479-3487, 1995.

111. Almkvist, J., Dahlgren, C., Leffler, H., and Karlsson, A. Newcastle disease virus neuraminidase primes neutrophils for stimulation by galectin-3 and formyl-Met-Leu-Phe. Exp.Cell Res., 298: 74-82, 2004.

112. Sano, H., Hsu, D. K., Yu, L., Apgar, J. R., Kuwabara, I., Yamanaka, T., Hirashima, M., and Liu, F. T. Human galectin-3 is a novel chemoattractant for monocytes and macrophages. J.Immunol., 165: 2156-2164, 2000.

113. Meromsky, L., Lotan, R., and Raz, A. Implications of endogenous tumor cell surface lectins as mediators of cellular interactions and lung colonization. Cancer Res., 46: 5270-5275, 1986.

114. Lemaire, S., Derappe, C., Michalski, J.-C., Aubery, M., and Neel, D. Expression of $\beta 1-6$-branched $\mathrm{N}$-linked oligosaccharides is associated with activation in human T4 and T8 cell populations. J.Biol.Chem., 269: 8069-8074, 1994.

115. Zuberi, R. I., Hsu, D. K., Kalayci, O., Chen, H. Y., Sheldon, H. K., Yu, L., Apgar, J. R., Kawakami, T., Lilly, C. M., and Liu, F. T. Critical role for galectin-3 in airway inflammation and bronchial hyperresponsiveness in a murine model of asthma. Am.J.Pathol., 165: 2045-2053, 2004. 
116. Raz, A., Meromsky, L., and Lotan, R. Differential expression of endogenous lectins on the surface of nontumorigenic, tumorigenic and metastatic cells. Cancer Res., 46: 3667-3672, 1986.

117. Raz, A., Meromsky, L., Zvibel, I., and Lotan, R. Transformationrelated changes in the expression of endogenous cell lectins. Int.J.Cancer, 39: 353-360, 1987.

118. Raz, A. and Lotan, R. Endogenous galactoside-binding lectins: a new class of functional tumor cell surface molecules related to metastasis. Cancer Metastasis Rev., 6: 433-452, 1987.

119. Danguy, A., Camby, I., and Kiss, R. Galectins and cancer. Biochim.Biophys.Acta, 1572: 285, 2002.

120. Van den, B. F., Califice, S., and Castronovo, V. Expression of galectins in cancer: a critical review. Glycoconj.J., 19: 537-542, 2004.

121. Iurisci, I., Tinari, N., Natoli, C., Angelucci, D., Cianchetti, E., and lacobelli, S. Concentrations of galectin-3 in the sera of normal controls and cancer patients. Clin.Cancer Res., 6: 1389-1393, 2000.

122. Castronovo, V., van den Brule, F. A., Jackers, P., Clausse, N., Liu, F.-T., Gillet, C., and Sobel, M. E. Decreased expression of galectin-3 is associated with progression of human breast cancer. J.Pathol., 179: 43-48, 1996. 
123. Idikio, H. Galectin-3 expression in human breast carcinoma: correlation with cancer histologic grade. Int.J.Oncol., 12: 1287-1290, 1998.

124. Yoshii, T., Inohara, H., Takenaka, Y., Honjo, Y., Akahani, S., Nomura, T., Raz, A., and Kubo, T. Galectin-3 maintains the transformed phenotype of thyroid papillary carcinoma cells. Int.J Oncol., 18: 787-792, 2001.

125. Takenaka, Y., Inohara, H., Yoshii, T., Oshima, K., Nakahara, S., Akahani, S., Honjo, Y., Yamamoto, Y., Raz, A., and Kubo, T. Malignant transformation of thyroid follicular cells by galectin-3. Cancer Lett., 195: 111-119, 2003.

126. Xu, X. C., El-Naggar, A. K., and Lotan, R. Differential expression of galectin-1 and galectin-3 in thyroid tumors. Potential diagnostic implications. Am.J.Pathol., 147: 815-822, 1995.

127. Mitra, S. K., Hanson, D. A., and Schlaepfer, D. D. Focal adhesion kinase: in command and control of cell motility. Nat.Rev.Mol.Cell Biol., 6: 56-68, 2005.

128. Shalom-Feuerstein, R., Cooks, T., Raz, A., and Kloog, Y. Galectin-3 regulates a molecular switch from N-Ras to K-Ras usage in human breast carcinoma cells. Cancer Res., 65: 7292-7300, 2005.

129. Moon, B. K., Lee, Y. J., Battle, P., Jessup, J. M., Raz, A., and Kim, H. R. Galectin-3 protects human breast carcinoma cells against nitric 
oxide- induced apoptosis: implication of galectin-3 function during metastasis. Am.J.Pathol., 159: 1055-1060, 2001.

130. Takenaka, Y., Fukumori, T., Yoshii, T., Oka, N., Inohara, H., Kim, H. R., Bresalier, R. S., and Raz, A. Nuclear export of phosphorylated galectin-3 regulates its antiapoptotic activity in response to chemotherapeutic drugs. Mol.Cell Biol., 24: 4395-4406, 2004.

131. Matarresea, P., Tinari, N., Semeraroa, M. L., Natolib, C., lacobelli, S., and Malorni, W. Galectin-3 overexpression protects from cell damage and death by influencing mitochondrial homeostasis. FEBS Lett., 473: 311-315, 2000.

132. Yoshii, T., Fukumori, T., Honjo, Y., Inohara, H., Kim, H. R., and Raz, A. Galectin-3 phosphorylation is required for its anti-apoptotic function and cell cycle arrest. J.Biol.Chem., 277: 6852-6857, 2002.

133. Akahani, S., Nangia-Makker, P., Inohara, H., Kim, H. R., and Raz, A. Galectin-3: a novel antiapoptotic molecule with a functional $\mathrm{BH} 1$ (NWGR) domain of Bcl-2 family. Cancer Res., 57: 5272-5276, 1997.

134. Liu, F. T. and Rabinovich, G. A. Galectins as modulators of tumour progression. Nat.Rev.Cancer, 5: 29-41, 2005.

135. Honjo, Y., Nangia-Makker, P., Inohara, H., and Raz, A. Downregulation of galectin-3 suppresses tumorigenicity of human breast carcinoma cells. Clin.Cancer Res., 7: 661-668, 2001. 
136. Ellerhorst, J. A., Stephens, L. C., Nguyen, T., and Xu, X. C. Effects of galectin-3 expression on growth and tumorigenicity of the prostate cancer cell line LNCaP. Prostate, 50: 64-70, 2002.

137. Califice, S., Castronovo, V., Bracke, M., and Van den, B. F. Dual activities of galectin-3 in human prostate cancer: tumor suppression of nuclear galectin-3 vs tumor promotion of cytoplasmic galectin-3. Oncogene, 23: 7527-7536, 2004.

138. Kim, H. R., Lin, H. M., Biliran, H., and Raz, A. Cell cycle arrest and inhibition of anoikis by galectin-3 in human breast epithelial cells. Cancer Res., 59: 4148-4154, 1999.

139. Lin, H. M., Pestell, R. G., Raz, A., and Kim, H. R. Galectin-3 enhances cyclin $\mathrm{D}(1)$ promoter activity through SP1 and a cAMPresponsive element in human breast epithelial cells. Oncogene, 21: 8001-8010, 2002.

140. Glinsky, V. V., Glinsky, G. V., Glinskii, O. V., Huxley, V. H., Turk, J. R., Mossine, V. V., Deutscher, S. L., Pienta, K. J., and Quinn, T. P. Intravascular metastatic cancer cell homotypic aggregation at the sites of primary attachment to the endothelium. Cancer Res., 63: 3805-3811, 2003

141. Khaldoyanidi, S. K., Glinsky, V. V., Sikora, L., Glinskii, A. B., Mossine, V. V., Quinn, T. P., Glinsky, G. V., and Sriramarao, P. MDA-MB-435 human breast carcinoma cell homo- and heterotypic 
adhesion under flow conditions is mediated in part by ThomsenFriedenreich antigen-galectin-3 interactions. J.Biol.Chem., 278: 4127-4134, 2003.

142. Khanna, C., Khan, J., Nguyen, P., Prehn, J., Caylor, J., Yeung, C., Trepel, J., Meltzer, P., and Helman, L. Metastasis-associated differences in gene expression in a murine model of osteosarcoma. Cancer Res., 61: 3750-3759, 2001.

143. Le Marer, N. and Hughes, R. C. Effects of the carbohydrate-binding protein galectin-3 on the invasiveness of human breast carcinoma cells. J.Cell Physiol, 168: 51-58, 1996.

144. O'Driscoll, L., Linehan, R., Liang, Y. H., Joyce, H., Oglesby, I., and Clynes, M. Galectin-3 expression alters adhesion, motility and invasion in a lung cell line (DLKP), in vitro. Anticancer Res., 22: 3117-3125, 2002.

145. Hittelet, A., Legendre, H., Nagy, N., Bronckart, Y., Pector, J. C., Salmon, I., Yeaton, P., Gabius, H. J., Kiss, R., and Camby, I. Upregulation of galectins-1 and -3 in human colon cancer and their role in regulating cell migration. Int.J.Cancer, 103: 370-379, 2003.

146. Debray, C., Vereecken, P., Belot, N., Teillard, P., Brion, J. P., Pandolfo, M., and Pochet, R. Multifaceted role of galectin-3 on human glioblastoma cell motility. Biochem.Biophys.Res.Commun., 325: 1393-1398, 2004. 
147. Nangia-Makker, P., Honjo, Y., Sarvis, R., Akahani, S., Hogan, V., Pienta, K. J., and Raz, A. Galectin-3 induces endothelial cell morphogenesis and angiogenesis. Am.J.Pathol., 156: 899-909, 2000.

148. Levy, Y., Arbel-Goren, R., Hadari, Y. R., Eshhar, S., Ronen, D., Elhanany, E., Geiger, B., and Zick, Y. Galectin-8 functions as a matricellular modulator of cell adhesion. J.Biol.Chem., 276: 3128531295, 2001.

149. Villa-Verde, D. M., Silva-Monteiro, E., Jasiulionis, M. G., Farias-deOliveira, D. A., Brentani, R. R., Savino, W., and Chammas, R. Galectin-3 modulates carbohydrate-dependent thymocyte interactions with the thymic microenvironment. European Journal of Immunology 32, no prelo. 2002.

150. Peterson, G. L. Review of the Folin phenol protein quantitation method of Lowry, Rosebrough, Farr and Randall. Anal.Biochem., 100: 201-220, 1979.

151. Laemmli, U. K. Cleavage of structural proteins during the assembly of the head of the bacteriophage T4. Nature, 227: 680-685, 1970.

152. Manes, S. and Martinez, A. Cholesterol domains regulate the actin cytoskeleton at the leading edge of moving cells. Trends Cell Biol., 14: 275-278, 2004. 
153. Rusnati, M., Urbinati, C., Tanghetti, E., Dell'Era, P., Lortat-Jacob, H., and Presta, M. Cell membrane GM1 ganglioside is a functional coreceptor for fibroblast growth factor 2. Proc.Natl.Acad.Sci.U.S A, 99: 4367-4372, 2002.

154. Smith, M., Brown, N. L., Air, G. M., Barrell, B. G., Coulson, A. R., Hutchison, C. A., III, and Sanger, F. DNA sequence at the C termini of the overlapping genes $A$ and $B$ in bacteriophage phi $\times 174$. Nature, 265: 702-705, 1977.

155. Avnur, Z. and Geiger, B. Substrate-attached membranes of cultured cells isolation and characterization of ventral cell membranes and the associated cytoskeleton. J.Mol.Biol., 153: 361-379, 1981.

156. Markus Niederreiter and Mario Gimona Isolation of Focal Adhesion from Cultured Cells. 1994.

157. Probstmeier, R., Montag, D., and Schachner, M. Galectin-3, a betagalactoside-binding animal lectin, binds to neural recognition molecules. J.Neurochem., 64: 2465-2472, 1995.

158. Ochieng, J., Leite-Browning, M. L., and Warfield, P. Regulation of cellular adhesion to extracellular matrix proteins by galectin-3. Biochem.Biophys.Res.Commun., 246: 788-791, 1998.

159. Lu, Y., Pelling, J. C., and Chaney, W. G. Tumor cell surface $\beta 1-6$ branched oligosaccharides and lung metastasis. Clin.Exp.Metastasis, 12: 47-54, 1994. 
160. Perillo, N. L., Marcus, M. E., and Baum, L. G. Galectins: versatile modulators of cell adhesion, cell proliferation, and cell death. J.Mol.Med., 76: 402-412, 1998.

161. Rabinovich, G. A., Baum, L. G., Tinari, N., Paganelli, R., Natoli, C., Liu, F. T., and lacobelli, S. Galectins and their ligands: amplifiers, silencers or tuners of the inflammatory response? Trends Immunol., 23: 313-320, 2002.

162. Chammas, R., Jasiulionis, M. G., Jin, F., Villa-Verde, D. M. S., and Reinhold, V. N. Carbohydrate-binding proteins in cell-matrix interactions. Brazilian J.Med.Biol.Res., 27: 2169-2179, 1994.

163. Ochieng, Josiah, Leite-Browning, Maria L., and Warfield, Paula. Regulation of cellular adhesion to extracellular matrix proteins by galectin-3. Biochemical and Biophysical Research Communications (246), 788-791. 1998.

164. Woo, H. J., Lotz, M. M., Jung, J. U., and Mercurio, A. M. Carbohydrate-binding protein 35 (Mac-2), a laminin-binding lectin, forms functional dimers using cysteine 186. J.Biol.Chem., 266 : 18419-18422, 1991.

165. Schlaepfer, D. D. and Mitra, S. K. Multiple connections link FAK to cell motility and invasion. Curr.Opin.Genet.Dev., 14: 92-101, 2004. 
166. Burridge, K. and Chrzanowska-Wodnicka, M. Focal adhesions, contractility, and signaling. Annu.Rev.Cell Dev.Biol., 12: 463-518, 1996.

167. del Pozo, M. A., Price, L. S., Alderson, N. B., Ren, X. D., and Schwartz, M. A. Adhesion to the extracellular matrix regulates the coupling of the small GTPase Rac to its effector PAK. EMBO J., 19: 2008-2014, 2000.

168. Zheng, Y., Bagrodia, S., and Cerione, R. A. Activation of phosphoinositide 3-kinase activity by Cdc42Hs binding to p85. J.Biol.Chem., 269: 18727-18730, 1994.

169. Keely, P. J., Westwick, J. K., Whitehead, I. P., Der, C. J., and Parise, L. V. Cdc42 and Rac1 induce integrin-mediated cell motility and invasiveness through PI(3)K. Nature, 390: 632-636, 1997.

170. Yamamoto, H., Swoger, J., Greene, S., Saito, T., Hurh, J., Sweeley, C., Leestma, J., Mkrdichian, E., Cerullo, L., Nishikawa, A., Ihara, Y., Taniguchi, N., and Moskal, J. R. Beta1,6-N-acetylglucosaminebearing $\mathrm{N}$-glycans in human gliomas: implications for a role in regulating invasivity. Cancer Res., 60: 134-142, 2000.

171. Zheng, M., Fang, H., and Hakomori, S. Functional role of Nglycosylation in $\alpha 5 \beta 1$ integrin receptor-de-N-glycosylation induces dissociation or altered association of $\alpha 5$ and $\beta 1$ subunits and 
concomitant loss of fibronectin binding activity. J.Biol.Chem., 269: 12325-12331, 1994.

172. Hughes, R. C. Roles of glycosylation in cell interactions with extracellular matrix. Biochem.Soc.Transactions, 20: 279-284, 1992.

173. Bellis, S. L. Variant glycosylation: an underappreciated regulatory mechanism for beta1 integrins. Biochim.Biophys.Acta, 1663: 52-60, 2004.

174. Yamamoto, H., Saito, T., Kaneko, Y., Kersey, D., Yong, V. W., Bremer, E. G., Mkrdichian, E., Cerullo, L., Leestma, J., and Moskal, J. R. alpha2,3-sialyltransferase mRNA and alpha2,3-linked glycoprotein sialylation are increased in malignant gliomas. Brain Res., 755: 175-179, 1997.

175. Laferte, S. and Dennis, J. W. Purification of two glycoproteins expressing beta 1-6 branched Asn-linked oligosaccharides from metastatic tumour cells. Biochem.J., 259: 569-576, 1989.

176. Laferte, S. and Loh, L. C. Characterization of a family of structurally related glycoproteins expressing beta 1-6-branched asparaginelinked oligosaccharides in human colon carcinoma cells. Biochem.J., 283 ( Pt 1): 193-201, 1992.

177. Yousefi, S., Higgins, E., Daoling, Z., Pollex-Kruger, A., Hindsgaul, O., and Dennis, J. W. Increased UDP-GIcNAc:Gal beta 1-3GaLNAcR (GIcNAc to GaLNAc) beta-1, 6-N-acetylglucosaminyltransferase 
activity in metastatic murine tumor cell lines. Control of polylactosamine synthesis. J.Biol.Chem., 266: 1772-1782, 1991.

178. Ko, J. H., Miyoshi, E., Noda, K., Ekuni, A., Kang, R., Ikeda, Y., and Taniguchi, N. Regulation of the GnT-V promoter by transcription factor Ets-1 in various cancer cell lines. J.Biol.Chem., 274: 2294122948, 1999.

179. Inohara, H. and Raz, A. Functional evidence that cell surface galectin-3 mediates homotypic cell adhesion. Cancer Res., 55: 3267-3271, 1995.

180. Ohannesian, D. W., Lotan, D., Thomas, P., Jessup, J. M., Fukuda, M., Gabius, H.-J., and Lotan, R. Carcinoembryonic antigen and other glycoconjugates act as ligands for galectin-3 in human colon carcinoma cells. Cancer Res., 55: 2191-2199, 1995.

181. Henrick, K., Bawumia, S., Barboni, E. A., Mehul, B., and Hughes, R. C. Evidence for subsites in the galectins involved in sugar binding at the nonreducing end of the central galactose of oligosaccharide ligands: sequence analysis, homology modeling and mutagenesis studies of hamster galectin-3. Glycobiol., 8: 45-57, 1998.

182. Sinkora, J., Kolinska, J., Rehakova, Z., Cerny, J., and Doubravska, L. Binding of the Galanthus nivalis agglutinin to thymocytes reveals alterations in surface glycosylation during T-cell development. Scand.J.Immunol., 55: 196-203, 2002. 
183. Starr, T. K., Daniels, M. A., Lucido, M. M., Jameson, S. C., and Hogquist, K. A. Thymocyte sensitivity and supramolecular activation cluster formation are developmentally regulated: a partial role for sialylation. J.Immunol., 171: 4512-4520, 2003.

184. Castronovo, V. Laminin receptors and laminin-binding proteins during tumor invasion and metastasis. Invasion Metastasis, 13: 1-30, 1996.

185. Tsuji, S., Datta, A. K., and Paulson, J. C. Systematic nomenclature for sialyltransferases. Glycobiol., 6: v-vii, 1996.

186. Moody, A. M., North, S. J., Reinhold, B., Van Dyken, S. J., Rogers, M. E., Panico, M., Dell, A., Morris, H. R., Marth, J. D., and Reinherz, E. L. Sialic acid capping of CD8beta core 1-O-glycans controls thymocyte-major histocompatibility complex class I interaction. J.Biol.Chem., 278: 7240-7246, 2003.

187. Cole, N. B. and Lippincot-Schwartz, J. Organization of organelles and membrane traffic by microtubules. Curr.Op.Cell Biol., 7: 55-64, 1995.

188. Crocker, P. R. and Feizi, T. Carbohydrate recognition systems: functional triads in cell-cell interactions. Curr.Op.Struct.Biol., 6: 679691, 1996. 
189. Wu, W., Harley, P. H., Punt, J. A., Sharrow, S. O., and Kearse, K. P. Identification of CD8 as a peanut agglutinin (PNA) receptor molecule on immature thymocytes. J.Exp.Med., 184: 759-764, 1996.

190. Rodgers, W. and Rose, J. K. Exclusion of CD45 inhibits activity of p56lck associated with glycolipid-enriched membrane domains. J.Cell Biol., 135: 1515-1523, 1996.

191. Zinkl, G. M., Zuk, A., can der Bijl, P., van Meer, G., and Matlin, K. S. An antiglycolipid antibody inhibits Madin-Darby Canine Kidney cell adhsion to laminin and interferes with basolateral polarization and tight junction formation. J.Cell Biol., 133: 695-708, 1996.

192. Fukushi, J., Makagiansar, I. T., and Stallcup, W. B. NG2 proteoglycan promotes endothelial cell motility and angiogenesis via engagement of galectin-3 and alpha3beta1 integrin. Mol.Biol.Cell, 15: 3580-3590, 2004.

193. Almkvist, J. and Karlsson, A. Galectins as inflammatory mediators. Glycoconj.J., 19: 575-581, 2004.

194. Feuk-Lagerstedt, E., Jordan, E. T., Leffler, H., Dahlgren, C., and Karlsson, A. Identification of CD66a and CD66b as the major galectin-3 receptor candidates in human neutrophils. J Immunol., 163: 5592-5598, 1999.

195. Sato, S., Ouellet, N., Pelletier, I., Simard, M., Rancourt, A., and Bergeron, M. G. Role of galectin-3 as an adhesion molecule for 
neutrophil extravasation during streptococcal pneumonia. J Immunol., 168: 1813-1822, 2002.

196. Wehrle-Haller, B. and Imhof, B. A. Integrin-dependent pathologies. J.Pathol., 200: 481-487, 2003.

197. Cinamon, G., Grabovsky, V., Winter, E., Franitza, S., Feigelson, S., Shamri, R., Dwir, O., and Alon, R. Novel chemokine functions in lymphocyte migration through vascular endothelium under shear flow. J.Leukoc.Biol., 69: 860-866, 2001.

198. Hughes, R. C. Galectins as modulators of cell adhesion. Biochimie., 83: 667-676, 2001.

199. Furtak, V., Hatcher, F., and Ochieng, J. Galectin-3 Mediates the Endocytosis of beta-1 Integrins by Breast Carcinoma Cells. Biochem.Biophys.Res.Commun., 289: 845-850, 2001.

200. Hsia, D. A., Mitra, S. K., Hauck, C. R., Streblow, D. N., Nelson, J. A., Ilic, D., Huang, S., Li, E., Nemerow, G. R., Leng, J., Spencer, K. S., Cheresh, D. A., and Schlaepfer, D. D. Differential regulation of cell motility and invasion by FAK. J.Cell Biol., 160: 753-767, 2003.

201. Angers-Loustau, A., Cote, J. F., and Tremblay, M. L. Roles of protein tyrosine phosphatases in cell migration and adhesion. Biochem.Cell Biol., 77: 493-505, 1999. 
202. Koistinen, P., Ahonen, M., Kahari, V. M., and Heino, J. alphaV integrin promotes in vitro and in vivo survival of cells in metastatic melanoma. Int.J.Cancer, 112: 61-70, 2004.

203. Hall, A. Rho GTPases and the actin cytoskeleton. Science, 279: 509-514, 1998.

204. Chong, C., Tan, L., Lim, L., and Manser, E. The mechanism of PAK activation. Autophosphorylation events in both regulatory and kinase domains control activity. J.Biol.Chem., 276: 17347-17353, 2001.

205. Kiosses, W. B., Daniels, R. H., Otey, C., Bokoch, G. M., and Schwartz, M. A. A role for p21-activated kinase in endothelial cell migration. J.Cell Biol., 147: 831-844, 1999.

206. Westwick, J. K., Lambert, Q. T., Clark, G. J., Symons, M., Van Aelst, L., Pestell, R. G., and Der, C. J. Rac regulation of transformation, gene expression, and actin organization by multiple, PAKindependent pathways. Mol.Cell Biol., 17: 1324-1335, 1997.

207. Lamarche, N., Tapon, N., Stowers, L., Burbelo, P. D., Aspenstrom, P., Bridges, T., Chant, J., and Hall, A. Rac and Cdc42 induce actin polymerization and G1 cell cycle progression independently of p65PAK and the JNK/SAPK MAP kinase cascade. Cell, 87: 519-529, 1996. 
208. Tolias, K. F., Cantley, L. C., and Carpenter, C. L. Rho family GTPases bind to phosphoinositide kinases. J.Biol.Chem., 270: 17656-17659, 1995.

209. Bornstein, P. Matricellular proteins: an overview. Matrix Biol., 19: $555-556,2000$.

210. Brekken, R. A. and Sage, E. H. SPARC, a matricellular protein: at the crossroads of cell-matrix. Matrix Biol, 19: 569-580, 2000.

211. Chlenski, A., Liu, S., Guerrero, L. J., Yang, Q., Tian, Y., Salwen, H. R., Zage, P., and Cohn, S. L. SPARC expression is associated with impaired tumor growth, inhibited angiogenesis and changes in the extracellular matrix. Int.J.Cancer, 2005.

212. Stupack, D. G. and Cheresh, D. A. Get a ligand, get a life: integrins, signaling and cell survival. J.Cell Sci., 115: 3729-3738, 2002.

213. Zagzag, D., Shiff, B., Jallo, G. I., Greco, M. A., Blanco, C., Cohen, H., Hukin, J., Allen, J. C., and Friedlander, D. R. Tenascin-C promotes microvascular cell migration and phosphorylation of focal adhesion kinase. Cancer Res., 62: 2660-2668, 2002.

214. Orr, A. W., Pallero, M. A., and Murphy-Ullrich, J. E. Thrombospondin Stimulates Focal Adhesion Disassembly through $\mathrm{Gi}$ - and Phosphoinositide 3-Kinase-dependent ERK Activation. J.Biol.Chem., 277: 20453-20460, 2002. 
215. Greenwood, J. A., Pallero, M. A., Theibert, A. B., and Murphy-Ullrich, J. E. Thrombospondin signaling of focal adhesion disassembly requires activation of phosphoinositide 3-kinase. J.Biol.Chem., 273: 1755-1763, 1998.

216. Hadari, Y. R., Arbel-Goren, R., Levy, Y., Amsterdam, A., Alon, R., Zakut, R., and Zick, Y. Galectin-8 binding to integrins inhibits cell adhesion and induces apoptosis. J.Cell Sci., 113 ( Pt 13): 23852397, 2000. 